\title{
POLYETHYLENE SOLIDIFICATION OF LOW-LEVEL WASTES
}

TOPICAL REPORT

Contributors

\begin{tabular}{l} 
George Arnold $\quad$ Eena-Wai Franz \\
Peter Colombo Mark Fuhrmann \\
Robert M. Doty Paul Kalb \\
\multicolumn{2}{c}{ Huan Zhou }
\end{tabular}

October 1984

Revised February 1985

NUCLEAR WASTE RESEARCH GROUP DEPARTMENT OF NUCLEAR ENERGY BROOKHAVEN NATIONAL LABORATORY ASSOCIATED UNIVERSITIES, INC. UPTON, LONG ISLANO, MEW YORK 11973
BNL --51867

DE85 012568

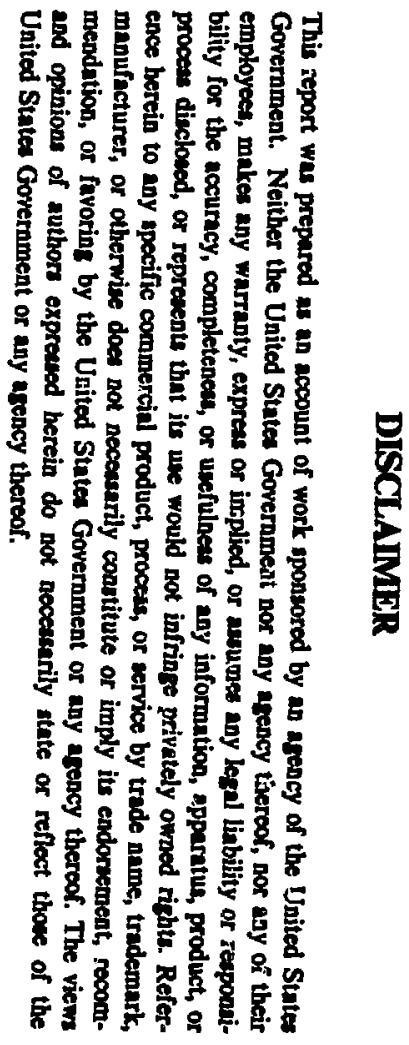

Prepared for the

UNITEO STATES DEPARTMENT OF ENERGY MATIONAL LOW-LEVEL WASTE MANAGEMENT PROGRAM UNDER CONTRACT NO. DE-ACO2-76CHOOO16 
Page.

ABSTRACT...................................................... ix

1. INTRODUCTION.............................................. 1

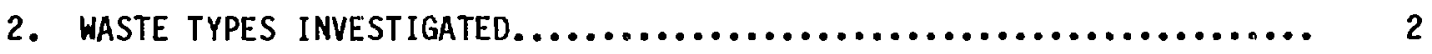

2.1 Background........................................... 2

2.2 Volume Reduction Wastes................................. 2

2.3 "Problem" Wastes....................................... 3

3. CHARACTERIZATION OF POLYETHYLENE............................ 4

3.1 Background............................................. 4

3.2 Properties of Polyethylene............................... 4

3.3 Types of Low-Density Polyethylenes Investigated ............. 6

4. PROCESS DEVELOPMENT STUDIES............................... 8

4.1 Preparation of Simulated Wastes........................... 9

4.2 Extrusion of Polyethy? ene................................... 10

4.2.1 Extruder Design.................................... 11

4.2.1.1 Grive Requirements...................... 13

4.2 .1 .2 Screw Design........................... 14

4.2 .1 .3 Temperature Control...................... 14

4.3 Laboratory-Scale Extruder.............................. 14

4.3.1 Extruder Instrumention......................... 14

4.3.2 Extruder Modifications......................... 17

4.3.2.1 Output Die Assembly..................... 17

4.3.2.2 Feed Assembly.......................... 17

4.4 Dual Hopper/Feeders.................................... 19

4.4.1 Calibration of Feed System......................... 20

4.4.2 Extruder Output Calibration......................... 21

4.5 Processing Parameters................................... 22

4.5.1 Temperature..................................... 22

4.5.2 Pressure.......................................... 22

4.5.3 Mixing Method...................................... 23

4.5.4 Feed and Extrusion Rates.......................... 23 
TABLE OF CONTENTS (cont.)

Page

4.5.5 Waste Pre-Treatment........................... 23

4.5 .6 Power Requirements........................... 24

4.5 .7 Solidification kinetics........................ 24

4.6 Process Development Results......................... 24

4.6.1 Solidification of Sodium Sulfate................. 25

4.6 .2 Solidification of Boric Acid.................... 25

4.6 .3 Solidification of Incinerator Ash................. 27

4.6.4 Solidification of Ion Exchange Resins................ 29

5. WASTE FORM PROPERTY EVALUATION STUDIES....................... 32

5.1 Introduction.................................. 32

5.2 Water Immersion Testing........................... 32

5.3 Deformation Under Compressive Load....................... 35

5.4 Themal Cyr.le Testing............................... 39

5.5 Leaching Tests................................... 44

5.5 .1 Leaching Test Method............................ 44

5.5 .2 Sample Preparation............................ 44

5.5 .3 Experimental Procedure......................... 46

5.5 .4 Leaching Results............................ 46

6. THE ECONOMICS OF VOLUME REDUCTION/POL YETHYLENE SOLIDIFICATION....... 54

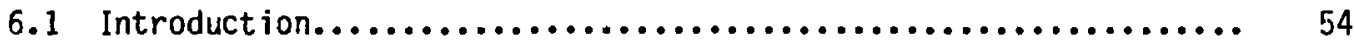

6.2 Technical and Economic Assumptions.................... 54

6.3 Economic Analysis............................... 55

6.4 Results..................................... 55

7. SUMMARY AND CONCLUSIONS............................. 58

REFERENCES.......................................... 63

APPENDIX A

APPENDIX B

APPENDIX C 


\section{LIST OF TABLES}

Table No. Page

3.1 Properties of Polyethylenes........................ 5

3.2 Average Properties of LDPE Materials Selected for

Investigation..................................... 7

4.1 Rotary Kiln incinerator Feed Composition................ 10

4.2 Maximum Sodium Sulfate Waste Loadings.................. 25

4.3 Maximum Boric Acid Waste Loadings.................... 27

4.4 Maximum Incinerator Ash Waste Loadings................. 29

4.5 Maximum Ion Exchange Resin Waste Loadings................ 31

5.1 Water Immersion Test Results for Polyethylene Waste Forms..... 34

5.2 Results of Waste Form Deformation Testing Under 100 psi

Compress ive Load.................................. 38

5.3 Results of Waste Form Deformation Testing Under 100 psi

Compressive Load for Thermal Cycled Specimens................ 40

7.1 Comparison of Optimal Recommended Waste Loadings in Polyethylene and Hydraulic Cement Based on Process

Control and Waste Form Performance Considerations............ 61 


\section{LIST OF FIGURES}

Figure No. $\quad$ Page

4.1 Sectional view of a simplified screw extruder............. 12

4.2 A typical production-scale single screw extruder........... 13

4.3 Photograph of the $11 / 4^{\prime \prime}$ diameter extruder screw............ 15

4.4 Some examples of improved extruder screw designs............ 15

4.5 Single screw extruder (as-received) used in the production of laboratory scale waste form spec imens..........................................

4.6 Photograph of laboratory-scale single screw extruder upon modification..................................

4.7 Hopper/Feeder assembly used for metering waste and polyethylene to the extruder at a pre-stt rate.............. 19

4.8 Cross-sectional view of a polyethylene waste form containing 70 wt\% sodiun sulfate, along with formulational constitutents......................................

4.9 Cross-sectional. view of a polyethylene waste form containing 10 wt\% incinerator ash, along with formulational constitutents.......................................

4.10 Cross-sectional view of a polyethylene waste form containing 50 wt\% ion exchange resins, along with formulational constitutents..........................

5.1 Stress strain curve for LDPE waste form incorporating

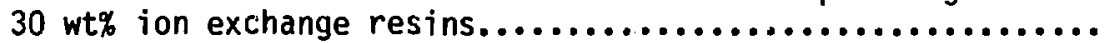

5.2 Photograph of compression test machine inodified to perform deformation testing according to ASTM $0-621 . . . . . .$.

5.3 Histogram depicting results of waste form deformation under compressive load for themal cycled and nonthermal cycled specimens................................

5.4 Photograph of microprocessor controlled thermal cycle envirommental chainber for conditioning specimens according to ASTM B-553.

5.5 Graphical representation of temperature conditions and duration for one thermal cycle.

5.6 Dual action heated mixing vessel emplayed for the production of polyethylene leaching specimens................ 


\section{LIST OF FIGURES (cont.)}

Figure No.

Page

5.7 Cumulative fractional activity release for polyethylene waste form containing 10 wt\% sodium sulfate.................

5.8 Cumulative fractional activity release for polyethylene waste form containing $30 \mathrm{wt} \%$ sodium sulfate............... 48

5.9 Cumulative fractional activity release for polyethylene waste form containing $50 \mathrm{wt} \%$ sodium sulfate................ 49

5.10 Comparison of the ${ }^{60}$ Co cumulative fractional activity release for polyethylene waste forms containing 10,30 ,

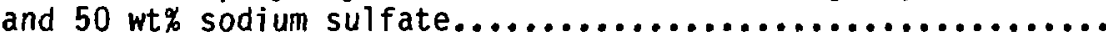

5.11 Cumulative fractional activity release for polyethylene waste form containing $25 \mathrm{wt} \%$ incinerator ash.

5.12 Cumulative fractional activity release for polyethylene waste form containing $35 \mathrm{wt} \%$ incinerator ash.

6.1 Total levelized annual cost (in millions of dollars) as a function of transportation distance to the burial site for each of the options considered... 


\section{ACKNOWLEDGMENTS}

The authors gratefully acknowledge the efforts of Mr. George E. Arnold for his valuable contributions in the production and testing of laboratory scale wasice forms. We also extend our appreciation to Ms. Kathy' P. Hauser for her efforts in typing this manuscript. 
This topical report describes the results of an investigation on the solidification of low-level radioactive waste in polyethylene. The work was conducted as part of the Waste Form Development/ Test Program, sponsored by ihe U.S. Department of Energy's Low-Level Waste Management Program.

Waste streams selected for this study included those which result from advanced volume reduction technologies (dry evaporator concentrate salts and incinerator ash) and those which remain problematic for solidification using contemporary agents (ion exchange resins). Four types of commercially available low density polyethylenes were employed which encornpass a range of processing and property characteristics.

Process development studies were conducted to ascertain opt imal process control parameters for successful solidification. Maximum waste loadings were determined for each waste and polyethylene type. Property evaluation testing was performed on laboratory scale specimens to assess the potential behavior of actual waste forms in a disposal enviroment. Waste form property tests included water immersion, deformation under compressive load, thermal cycling and radionuclide leaching.

Recommended waste loadings of $70 \mathrm{wt} \%$ sodium sulfate, $50 \mathrm{wt} \%$ boric acid, $40 \mathrm{wt} \%$ incinerator ash, and $30 \mathrm{wt} \%$ ion exchange resins, which are based on process control and waste form performance considerations are reported. 


\section{INTRODUCTION}

This investigation of polyethylene as a potential radwaste solidification agent has been performed as part of the Waste Form Development/Test program, sporisored by the U.S. Department of Energy's Low-Level Waste Management program. The primary objective of the Waste Form program is the application of materials and processes which are not currently employed in the United States for the improved solidification of low-level radioactive wastes (LLW).

A survey of potential agents was conducted during FY 1983 and polyethylene was designated as a leading candidate for further investigation 1,2 . Selection criteria as outlined in the Letter Report to DOE ${ }^{1}$, were based on such considerations as compatibility with waste, material properties, solidification efficiency, ease of processibility and economic feasibility.

Polyethylene is a thermoplastic polymer and thus may be heated above its melting point, combined with waste to form a homogeneous mixture and allowed to cocl resulting in a monolithic solid waste form. In contrast to contemporary solidification agents such as hydraulic cement or thermosetting polymers, no chemical reaction is required for solidification. This provides a number of advantages. Waste stream compatibility is expanded in that constituents present in the waste will not inhibit solidification. Processing by plant personnel is simplified since variations in waste composition over time would not require adjustment of the solidification chemistry.

Polyethylene was suggested as a material for the encapsulation of LLW a number of years ago by workers at 0ak Ridge National Laboratory ${ }^{3}$, but work towards its further development was not actively pursued in the United States. Changes in the economic climate, reduction in the availability of shallow land burial sites, increased emphasis in improved waste form performance, as well as recent improvements in waste treatment technology were a11 contributing factors in the renewed interest in this material. The development of polyethylene as a potential binder for LLW has not been limited to the United States. The Japanese have published several papers describing their research efforts in this regard 4,5 .

This topical report describes the research and development work performed at BNL in the areas of polyethylene process development and waste form property evaluation studies. Simulated 1aboratory scale waste forms were produced using four types of $10 \mathrm{w}$-density polyethylene, and encompassing a number of waste types. Relevant process control parameters necessary for successful solidification are defined and maximum waste loadings achievable are reported. A series of laboratory waste form property tests were conducted to help predict the behavior of actual waste forms in a disposal environment. In addition, an economic analysis was performed to compare the relative costs of polyethylene and cement solidification technologies. 


\section{WASTE TYPES INVESTIGATED}

\subsection{Background}

Large volumes of low-level radioactive waste are routinely generated through the operation of defense-related and commercial nuclear facilities. In 1982, D0E/defense activities produced some 89.1 cubic meters of $L L W$, whereas, the commercial sector generated 75.9 cubic meters 6 . These wastes are diverse in chemical and physical composition, but can broadly be defined as either aqueous or dry active wastes (DAW).

Aqueous wastes consist primarily of fission and activation products removed from process streams to reduce radiation and/or contamination hazards to plant personnel. A number of processing techniques are employed to remove radioactive elements from these streams such as ion exchange, evaporation, reverse osmosis, flocculation, and filtration. Each of these techniques, while effective for the removal and concentration of activity, still result in some form of radioactive waste which must ultimately be disposed. Waste streams thus produced include ion exchange resins, evaporator concentrates, filtration sludges, and contaminated filters and membranes. According to current NRC regulations contained in 10 CFR 61 , all liquid waste streams must be stabilized by either solidification or use of a high integrity container?. An increased emphasis on waste stabilization is also being promulgated by DOE for the treatment and disposal of defense related waste streams.

Dry active wastes are produced at virtually all facilities involved with nuclear materials. These wastes such as paper, rags, clothing and plastics are currently compacted in 55 galllon drums or larger vessels. Many of these wastes however may be incinerated with a large reduction in waste volume resulting.

Waste streams selected for this investigation as reported in the Letter Report to $D^{\circ} E^{8}$, and reviewed in the sections following include, I) those which result from advanced volume reduction technologies (for both aqueous and dry active wastes), and 2) those which continue to be problematic for solidification using contemporary materials and processes.

\subsection{Volume Reduction Wastes}

Solidification efficiences for aqueous concentrate wastes encapsulated using contemporary agents are often 1 imited by chemical interactions between the waste and binder. Advanced volume reduction processes such as fluidized bed calciners are now available which can reduce these liquid concentrates to a dry solid condition. By doing so, waste stability is improved and aqueous waste volumes can be reduced by factors ranging between six and twelve (depending upon original waste composition) ${ }^{9}$. Combustible dry active wastes can be treated by a number of currently available incineration technologies including rotary kiln, controlled air, fluidized bed, molten salt, cyclone and pyrolysis incineration. Depending upon the process and the composition of the waste input, incineration can achieve reductions in waste volume of as much as 100 -fold 10 . 
In addition to increased stability, the benefits inherent in the use of advanced volume reduction of low-level waste include:

- Extension of current and future shallow land burial capacity.

- Reduction in over-the-road shipments of radioactive waste.

- Potential overall cost savings for the disposal of LLW (as discussed in Section 6).

For these reasons, it is felt that the use of volume reduction technologies will become increasingly prevalent. As such, the incorporation of the resulting dry solid residues in polyethylene is covered in this study.

\section{3 "Problem" Wastes}

Due to their excellent sorption capacities, ion exchange resins serve a number of vital functions in the effective operation of nuclear facilities. Although resin wastes account for a relatively small fraction of LLW on the basis of volume, they contain a significant fraction of the radjoactivityli. Hydraulic cement is commonly used for the solidification of spent ion exchange resins. However, due to physicochemical interactions between the resin and cement which cause severe degradation of waste form mechanical integrity, waste loading efficiencies tend to be poor. In earlier studies performed at BNL it was shown that a maximum of approximately 13 weight percent dry ion exchange resins could be successfully incorporated in portland cement 12 . Ion exchange resins are therefore considered a "problem waste" and are included in this study.

In summary, waste form development and property evaluation studies for polyethylene have been performed incorporating the following waste types:

- sodium sulfate evaporator concentrate salts

- bcric acid evaporator concentrate salts

- incinerator ash

- jon exchange resins

Preparation of simulated wastes for use in process development and property evaluation studies are discussed in Section 4.1 . 


\section{CHARACTERIZATION OF POLYETHYLENE}

\subsection{Background}

Polyethylene was first developed in 1933 by Imperial Chemical Industries, Ltd., as a result of research on the high pressure chemistry of organic compounds. Their first industrial scale process was on-line in 1939. Use of polyethylene for cable insulation during World War II created an immediate demand for this product and led to the establishment of production facilities by Union Carbide and Du Pont. Over the next 45 years materials and processing refinements expanded the potential applications of this product to such an extent that today it is the most widely used of all plastics. Current production capacity for the 16 commercial producers in the U.S. alone is over $4 \times 10^{6}$ metric tons 13 .

\subsection{Properties of Polyethylene}

Polyethylene is an organic polymer material of crystalline-amorphous structure, formed through the polymerization of ethylene gas. Hundreds of compound variations with differing properties are at:ainable by the control and design of its molecular structure. Such structural variations are produced by the manifulation of process parameters and the use of selected additives.

The degree of crystallinity determines density, which in turn affects a range of material properties. Two basic processes are employed in the production of polyethylene. Low density polyethylene (LDPE) is produced by a process which utilizes high reaction pressures $(15,000$ to 45,000 psi) resulting in the formation of large numbers of polymer branches. These branches occur at a frequency of 10-20 per 1000 carbon atoms, creating a relatively open structure. Typically, low density polyetrylenes have densities ranging between 0.910 and $0.925 \mathrm{~g} / \mathrm{cm}^{3} .14 \mathrm{High}$ density polyethylene (HDPE) is manufactured by a low pressure ( $<1500$ psi) process in the presence of special catalysts which allow the formation of long linear chains of polymerized ethylene. Very few side chain branches in the HDPE molecule result in a close packed or dense structure. HDPE densities range between 0.941 and 0.959 $\mathrm{g} / \mathrm{cm}^{3}$. Medium density polyethylenes $\left(0.926-0.940 \mathrm{~g} / \mathrm{cm}^{3}\right)$ can be formulated by either high or low pressure methods, or by combining LDPE and HDPE materials.

The properties of low, mediun, and high density polyethylenes are compared in Table 3.1. These data indicate that the properties of high density polyethylene, e.g., mechanical strength and resistance to harsh chemical environments might provide a slight advantage vis-a-vis the solidification of low-level radioactive waste. Processing of high density polyethyl tne is more difficult, however, as it requires greater temperatures and pressures. The properties of low derisity polyethylene are none-the-less favorable, and thus it was selected for use in these studies based upon the relative ease of processibility. 
Properties of Polyethylenes(a)

\begin{tabular}{|c|c|c|c|}
\hline Property & Low Density & Medium Density & High Density \\
\hline Compression Molding Temp, ${ }^{\circ} \mathrm{C}$ & $135-177$ & $150-315$ & $150-230$ \\
\hline Density, $g / c c$ & $0.910-0.925$ & $0.926-0.940$ & $0.941-0.965$ \\
\hline $\begin{array}{r}\text { Tensile Strength, } \mathrm{MPa} \\
\qquad(\mathrm{psi})\end{array}$ & $\begin{array}{c}4.14-15.86 \\
600-2300\end{array}$ & $\begin{array}{l}8.27-24.13 \\
1200-3500\end{array}$ & $\begin{array}{c}21.37-37.92 \\
3100=5500\end{array}$ \\
\hline $\begin{array}{r}\text { Compressive Strength, } \begin{array}{c}\mathrm{MPa} \\
(\mathrm{psi})\end{array}\end{array}$ & 二 & 二 & $\begin{array}{c}18.61-24.82 \\
2700-3600\end{array}$ \\
\hline $\begin{array}{l}\text { Water Absorbance, } \\
\left(24 \mathrm{hr}, 1 / 8^{\prime \prime} \text { thick, q) }\right.\end{array}$ & $<0.01$ & $<0.01$ & $<0.01$ \\
\hline Flammability (Burn Rate, in/min) & 1.04 & $1.00-1.04$ & $1.00-10.4$ \\
\hline Average Extent of Burning, in. & 0.8 & 0.6 & - \\
\hline Average Time of Burning, sec. & $<5-25$ & $10-60$ & - \\
\hline Effect of Weak Acid & Resistant & Very Resistant & Very Resistant \\
\hline Effect of Strong Acid & $\begin{array}{l}\text { Attacked by } \\
\text { Oxidizing Acids }\end{array}$ & Attacked Slowly & Attacked Slowly \\
\hline Effect of Weak Alkalies & Resistant & Very Resistant & Very Resistant \\
\hline Effect of Strong Alkalies & Resistant & Very Resistant & Very Resistant \\
\hline Effect of Organic Solvents & $\begin{array}{l}\text { Resistant Below } \\
60^{\circ} \mathrm{C} \text { Except to } \\
\text { Chlorinated Solvents }\end{array}$ & $\begin{array}{l}\text { Resistant Be? ow } \\
60^{\prime} \text { C Except to } \\
\text { Ch? orinated Solvents }\end{array}$ & Resistant Below $80^{\circ} \mathrm{C}$ \\
\hline
\end{tabular}

(a) Data dram from13. 
In addition to density, other structural phenomena which affect polyethylene properties include molecular weight, molecular weight distribution, and melt index. The molecular weight is the average of all sizes of polymer chains produced during polymerization15. Low-density polyethylenes are available in a wide range of molecular weights. Those with high molecular weights tend to have improved toughness, resistance to harsh chemical environments, and better stress crack resistance. However, these materials are also more difficult to process. Polymers are made up of molecules of varying chain length and the molecular weight distribtuion describes the range of chain sizes present. Both molecular weight and molecular weight distribution may be determined by gel permeation chromatography. Typically, the molecular distribution for LDPE's ranges between 2.5:1 to 18:1. This parameter has a less dramatic effect on polyethylene properties than the molecular weight itself, but in general a narrow molecular weight distribution provides an optimal balance between mechanical properties and ease of faisrication.

The melt index is a measure of the viscosity of the melt (the ease with which it flows) at $190^{\circ} \mathrm{C}$ and has units of grams/10 minutes. These units originate from the ASTM Test Method D-1238 which measures the rate of extrusion of thermoplastics through an orifice under prescribed temperature and pressure conditior.j. Melt index may also be used to describe molecular weight as the two parameters are inversely proportional. Values for the melt index can range from $<1 \mathrm{~g} / 10$ minutes for high molecular weight polyethylene to $>4000$ g/10 minutes for some low molecular weight polyolefins. For typical applications however, polyethylenes have melt index values ranging between 1 and 60 $\mathrm{g} / 10$ minutes.

\subsection{Types of Low-Density Polyethylenes Investigated}

Low density polyethylenes are commercially available with a wide variety of physical properties and diverse processing requirements.

A number of these materials were selected from several manufacturers for potential application. They represent a range in density, molecular weight, and melt index, and are listed along with some of their properties in Table 3.2 These materials are employed commercially in the production of coatings and films and for extrusion and injection molding of plastic components.

Thermoplastic material properties such as melt index can have a dramatic effect on processing parameters including melt temperature, pressure and extrusion rate. Preliminary investigations as discussed in Section 4,examined these inter-relationships to determine their impact on waste form production using a bench scale extruder. Process development studies were then conducted with a number of LDPEs to determine maximum waste loadings and specific process control requirements for each. As mentioned earlier, the physical properties of polyethylene may vary with material characteristics such as melt index. Property evaluation studies were conducted for waste forms solidified with several types of LDPEs to determine the relative effects of material properties on waste form product performance. The selection of polyethylene type best suited for each waste stream was thus based upon a balance between achievable waste loadings, process control requirements and the results of waste form performance testing. 
Table 3.2

Average Properties of LDPE Materials Selected for Investigation(a)

\begin{tabular}{|c|c|c|c|c|c|}
\hline $\begin{array}{l}\text { LDPE } \\
\text { Iype }(g)\end{array}$ & $\begin{array}{l}\text { End } \\
\text { Use }\end{array}$ & $\begin{array}{l}\text { Density }(b) \\
-\mathrm{g} / \mathrm{cm}^{3}\end{array}$ & $\begin{array}{l}\text { Melt Index }(c) \\
\text { g/10 min }\end{array}$ & $\begin{array}{l}\text { Molecul ar(d) } \\
\text { Weight }\end{array}$ & $\begin{array}{l}\text { Molecular } \\
\text { Weight } \\
\text { Distribution (e) }\end{array}$ \\
\hline $\begin{array}{l}\text { Gulf } \\
1117-B\end{array}$ & $\begin{array}{l}\text { Extruded } \\
\text { Film }\end{array}$ & 0.924 & 2.0 & NA $(f)$ & NA \\
\hline $\begin{array}{l}\text { Gulf } \\
14 \mathrm{GO}\end{array}$ & $\begin{array}{l}\text { Injection } \\
\text { Molding }\end{array}$ & 0.924 & 8.0 & 70,000 & 3.0 \\
\hline $\begin{array}{l}\text { Gulf } \\
1408.5\end{array}$ & $\begin{array}{l}\text { Injection } \\
\text { Molding }\end{array}$ & 0.924 & 27.0 & 60,000 & 2.5 \\
\hline $\begin{array}{l}\text { Gulf } \\
1410\end{array}$ & $\begin{array}{l}\text { Injection } \\
\text { Molding }\end{array}$ & 0.924 & 35.0 & 55,000 & 2.5 \\
\hline $\begin{array}{l}\text { Gulf } \\
1409\end{array}$ & $\begin{array}{l}\text { Injection } \\
\text { Molding }\end{array}$ & 0.924 & 55.0 & 40,000 & 2.5 \\
\hline $\begin{array}{l}\text { Eastman } \\
C-14\end{array}$ & $\begin{array}{l}\text { Non-Emulsi- } \\
\text { fiable Wax }\end{array}$ & 0.918 & 1.6 & 23,000 & 3.8 \\
\hline $\begin{array}{l}\text { Eastman } \\
C-17\end{array}$ & $\begin{array}{l}\text { Non-Emulsi- } \\
\text { fiable Wax }\end{array}$ & 0.917 & 20.0 & 19,000 & 3.6 \\
\hline
\end{tabular}

\footnotetext{
a) Data as supplied by manufacturers

b) Determined by ASTM Test Method D1505

c) Determined by ASTM Test Method D1238

d) Determined by Gel Permeation Chromatography (GPC)

e) Ratio of weight average molecular weight to number average molecular weight.

f) Not available

g) Manufactured by: Gulf $0 i 1$ Chemicals, Houston, TX and Eastman Chemical Products, Kingsport, TN
} 


\section{PROCESS DEVELOPMENT STUDIES}

Due to the diverse physical and chemical composition of radioactive waste streams, the effective application of any new solidification binder material requires a comprehensive investigation of processing requirements. To this end, process development studies were conducted for polyethylene in order to:

- select the optimal processing technology

- verify waste-binder compatibility

- determine processing parameters of interest

- ascertain the effects of these parameters on the successful encapsulation of various waste streams

- optimize process parameters to achieve maximum waste form volumetric efficiencies

- develop a data base of relevant laboratory-scale process control information to be used as a basis for the production of larger scale waste forms.

A number of processing techniques were surveyed for use with low density polyethylene including batch heating vessels, wiped film evaporators and screw extruders. Based on such considerations as ease of processibility, quality control, and the use of a proven and available technology, the extrusion method was selected. This process, which employs a simuitaneous mixing and heating of the waste-binder mixture, is described in detail in Section 4.2. Polyethylene is a thermoplastic material with properties which makes it well suited for processing via this technique as evidenced by numerous applications in the plastics industry.

Physical and chemical compatibility of the polyethylene matrix with each of the waste streams was a primary concern, and was thus the focus of initial scoping studies performed in FY 1983. The impact on processing caused by variations in physical form (such as particle size, density, hardness, etc.) between the waste and binder materials was considered. Chemical interactions could also present possible processing difficulties. Potential problem areas identified were investigated further during more comprehensive process development studies (FY 1984). Processing limitations were more precisely defined and problem areas mitigated, where possible.

The production of a successful waste form product is dependent upon the control of processing parameters within a finite operating range. The effect of adding materials such as radwaste serves to narrow this range and thus place further emphasis on the precise control and monitoring of the system. Scoping work identified a number of important parameters and further process development work provided information regarding system sensitivity toward each. The processing factors of interest which are discussed in Section 4.5 include: 
- Process temperatures - minimum, maximum and optimum temperatures for processibility.

- Process pressures - especially where excessive pressures interfere with effective system operation.

- Nixing method - static pre-mix vs. dynamic blending of waste and binder materials.

- Feed and processing rates - impact of rates on processibility and overall product integrity.

- Waste pre-treatment - determination of system requirements for feed stock materials, if any.

- Power requirements - current draw as an indicator of mechanical stress on components.

- Solidification kinetics - output die design; methods and rates for waste form product conling.

The volumetric efficiency, or quantity of waste which can successfully be incorporated in each solidification matrix material is an important economic consideration. Process parameters discussed above were optimized to achieve maximum waste form loadings for each waste type, the results of which are reported in Section 4.6. Typical waste loadings were then applied as input to the economic analysis presented in Section 6 .

The demonstration of the polyethylene process on a scale approximate to that required in actual operation will be performed in FY 1985-1986. Laboratary-scale process information will be used as a data base for operation of this facility to minimize duplication of effort.

\subsection{Preparation of Simulated Wastes}

Laboratory scale waste forms were fabricated for both process development and property evaluation studies using non-radioactive, simulated wastes. Materials were selected which closely resemble actual wastes in both physical and chemical composition.

Evaporator concentrates which have been brought to a dry solid state were simulated using anhydrous sodium sulfate $\left(\mathrm{Na}_{2} \mathrm{SO}_{4}\right)$ reagent and orthoboric acid $\left(\mathrm{H}_{3} \mathrm{BO}_{3}\right)$ reagent. The actual form of boric acid produced through volume reduction is dependent upon treatment conditions. When processed at temperatures in excess of $170^{\circ} \mathrm{C}$ metaboric acid results. It should also be noted that compositional variations in specific waste feed streams may alter the chemical form of volume reduction wastes. Since polyethylene does not chemically react with these waste products, such variations are not expected to significantly affect the results reported here. Both $\mathrm{Na}_{2} \mathrm{SO}_{4}$ and $\mathrm{H}_{3} \mathrm{BO}_{3}$ simulated waste were employed as a fine, dry powder with bulk densities of 1.46 and $1.44 \mathrm{~g} / \mathrm{cm}^{3}$ respective1y. In contrast to chemical form, variations in the physical form of the waste may affect such processing parameters as feed rates, screw speed and melt temperatures. 
Incinerator ash generated at the Rockwell International Rocky Flats Plant rotary kiln incinerator was employed as a typical volume reduction ash product. This ash was produced by burning simulated waste, with constituents equivalent to those present in actual combustible LLW from this facility as shown in Table 4.116 .

Table 4.1

Rotary Kiln Incinerator Feed Composition

\begin{tabular}{lr} 
Constituent & Weight \\
\cline { 2 - 2 } Paper & 40.0 \\
Polyethylene & 22.8 \\
Neoprene & 18.8 \\
Kerosene & 9.5 \\
Polyvinyl Chloride & 7.9 \\
Tributyl Phosphate & 1.0
\end{tabular}

As received, the ash had a bulk density of approximately $0.23 \mathrm{~g} / \mathrm{cm}^{3}$. Since particle size was non-uniform the ash was put through a No. 8 sieve, resulting in a maximum particle size of $2.38 \mathrm{~mm}$. This procedure improved waste homogeneity, assuired inore precise feeding and prevented process equipment failures by the introduction of excessively large ash particles.

Unloaded mixed-bed ion exchange resin beads manufactured by Rohm and Haas Corp., Philadelphia, PA, were used to simulate reactor resins. Although actua) reactor resin waste is chemically loaded, the use of unloaded resins is not expected to alter results since no free ions are available to interact within the polyethylene matrix. A ratio of two parts cation resin (IRN-77) to one part anion resin (IRN-78) was selected as representative of a typical reactor demineralizer system. Resin bead particle sizes range between 0.5 and $1.0 \mathrm{~mm}$ in diameter. As-received resins (2:1 mixed-bed) have a density of approximately $1.21 \mathrm{~g} / \mathrm{cm}^{3}$ and contained approximately 58 percent moisture by weight. Typically ion exchange resins at reactors are maintained in a slurry (containing about 80 weight percent moisture) to facilitate transfer operations. Prior to processing with polyethylene, the resins were oven dried uvernight at $110^{\circ} \mathrm{C}$. This step was necessitated by design constraints of the bench scale extruder, which preclude the presence of moisture.

\subsection{Extrusion of Polyethylene}

Extruders were originally developed in the first half of the nineteenth century and were used by the Italian food industry for the production of macaroni. Screw-type extruders were first employed in the United States in the rubber industry and were adapted for the.extrusion of themoplastics in 193817 . The use of extruders for the processing of various thermoplastic materials is commonplace in industry today. Experience in the incorporation of dry solids such as graphite powders or fiberglass for increased mechanical 
strength of plastics, is prevalent as well. Although the feasibility of LDPE as a radwaste matrix material has been demonstrated using wiped film evaporator technology $3,4,5$ no experience is available in this country and little on a worldwide basis for the use of an extrusion system in this application.

Extrusion can be defined as the transformation of raw materials into a homogeneous product by forcing the material through a die. The process can be accomplished by either a wet or dry method. The wet method which has only 1 imited application involves the use of solvents to help soften the material for extrusion. Extrusion of polyethylene is performed exclusively by the dry method in which heat is applied to achieve softening.

An extruder consists of four basic cumponents, as depicted in the simplified schematic diagram in Figure 4.1. These are: 1) a feed hopper, 2) a rotating auger-1ike screw, 3) a heated cylinder in which the screw rotates and 4) an output die assembly to shape the final product.

The extrusion process for solidification of radioactive waste in polyethylene involves the heating, mixing and extruding of materials in one basic operation. To more clearly understand this process, it may be broken down into the following steps:

- The polyethylene binder and dry waste materials are transferred from either a single hopper or individual hoppers in which they are stored to the extruder feed throat. Metering of waste-tobinder ratios is accomplished at this step.

- The mixture is conveyed through a heated cylinder by the motion of the rotating screw. The initial portion of the cylinder is controlled at a temperature below the polyethlene melting point. This serves to gradually pre-heat the materials but at the same time assures proper transport of the mixture.

- As the waste-binder mixture moves forward past the initial pre-heating zone, it is masticated under pressure due to the compressive effects of a gradual reduction in the channel area between the screw and cylinder. Screw rotation also assists in the mixing of the materials to a homogeneous state.

- The gradual transfer of thermal energy by the combined effects of the barrel heaters and frictional heat serves to melt the mixture. The frictional heat input is difficult to control and must be compensated for by the regulation of the resistance band heaters. In some cases it is necessary to remove excessive heat by the use of external blowers.

- The melted thermoplastic-waste mixture is forced through an output die into a mold and is allowed to cool and solidify.

4.2.1 Extruder Design: Extruders are available in either a single screw design, as described in the discussion on the principles of polyethylene extrusion, or in a multiple screw configuration. Multiple screw design provides 


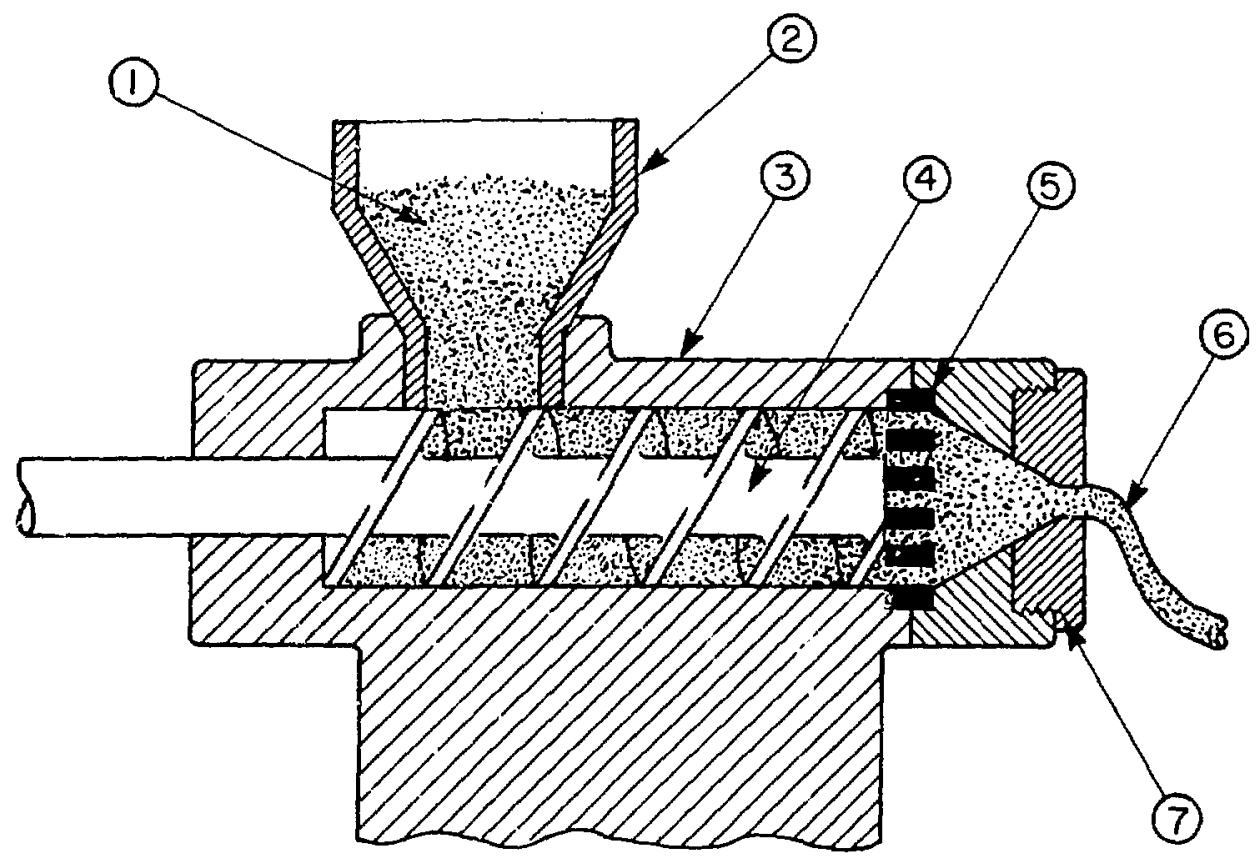

KEY
(1) Feed Material
(2) Feed Hopper
(3) Heating Unit
(4) Mechanical Screw
(5) Strainer
(6) Extruded Product
(7) Die

Figure 4.1 Sectional view of a simplified screw extruder. The sketch depicts flow of material from the hopper to the output die, where it is extruded in a molten state. Redrawn from Reference 17. 
additional mixing action and therefore may provide benefits for radwaste solidification applications. Twin screw extruders manufactured by Werner and Pfleiderer and marketed by Waste Chem, Ramsey, NJ, are currently being used for waste encapsulation in bitumen. Multiple screw machines are more complex, however, and tend to wear more quickly and incur higher maintenance costs. The bench scale extruder employed in these studies is a single screw model and further discussions will focus on this type.

\subsubsection{Drive Requirements: A typical production-scale single} screw extruder and its primary miechanical components is shown in Figure 4.2. To power the extruder screw and provide sufficient torque to overcome the resistance of solid and molten materials, a drive motor and gear reduction system are needed. The action of the reciprocating screw creates a backward thrust which is absorbed by the thrust bearing assembly. In addition to furnishing power, the extruder drive must be able to vary and maintain precise speed settings, regardless of the load conditions in order to provide reproducible resuits. Alternating current (a.c.) motors may be used, but more commonly direct current (d.c.) rectified equipment is employed. This system combines a d.c. motor with a sol id state silicon control rectifier (SCR) device, and offers mechanical simplicity, accurate speed control, efficient energy usage, constant torque over a broad speed range, and low maintenancelo.

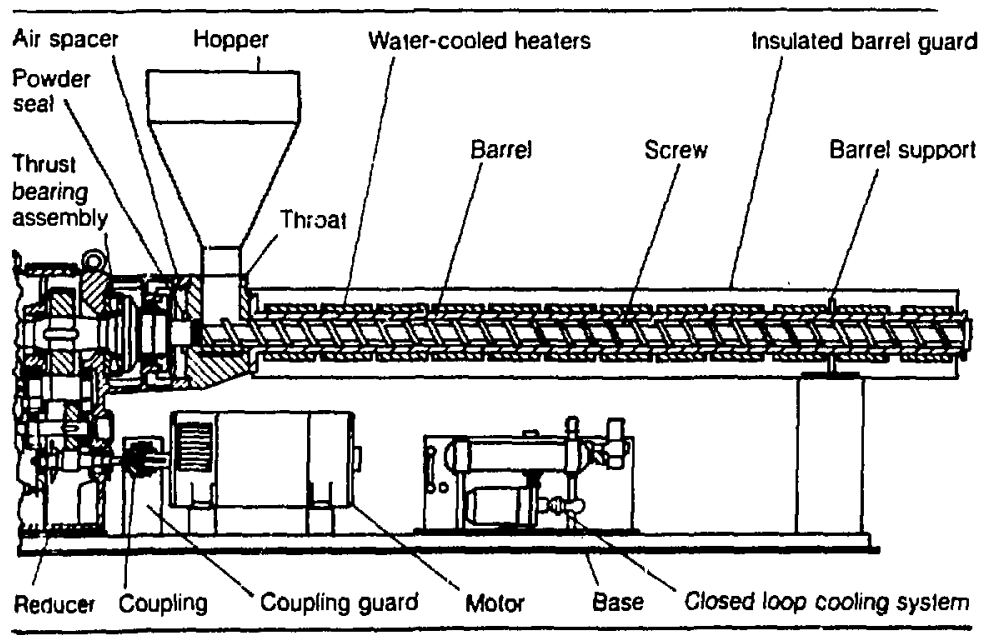

Figure 4.2 A typical production-scale single screw extruder ${ }^{18}$. 
4.2.1.2 Screw Design: The extruder output rate is constrained by its internal volume, which is generally specified in terms of screw size. Screws, in turn, are described by their outside diameter (U.D.) and length to diameter ratio (L/D). Extruders are availatle with screw sizes ranging from $3 / 4$ inch 0.D. for lab-scale applications to greater than 6 inch 0.0 . for some production level machines. The $L / D$ ratio is determined according to the residence time required to nelt, mix and discharge the extrudite.

Conventional extruder screws contain feed, transition and metering sections, as shown in Figure 4.3. Recently, design modifications have been introduced which provide improvements in the melting and homogenization of materials. A few of these designs are shown in Figure 4.4.

4.2.1.3 Temperature Control: Extrusion heating is generally supplied by electrical resistance band heatars, but some machines utilize steam or heat transfer fluids. A means of cooling is provided either by blowers or liquid circulation. Precise contro! of the material temperature is required for successful extrusion. For electrically heated/cooled systems, this is accomplished through the use of solid state, time proportioning devices which are designed to provide rapid and precise temperature control.

\subsection{Laboratory-Scale Extruder}

Laboratory-scale waste forms for process development studies were produced using a Model KL-125 single screw extruder manufactured by Killion Extruders, Inc., Verona, $\mathrm{NJ}^{19}$. A schematic view of the extruder, asreceived, is included as Figure 4.5.

This machine is equipped with a $11 / 4$ inch diameter chrome plated screw with a length to diameter ratio (L/D) of $24 ! 1$ and compression ratio of $3 / 1$ as shown in Figure 4.3. The screw is powered by a 3 norespower d.c. drive electric motor with electronic SCR speed contral through a 15:1 gear reduction. Screw speed can thus be varied between 12 and 120 RPM.

The $21 / 2$ inch 00 barrel is fabricated of 4140 steel and is Xaloy lined. This barrel is heated by three separately contolled heat zones consisting of 1250 watt electric resistance mica band heaters. A separate die zone heater is used. In order to provide more precise control of barrel temperatures, the unit is equipped with three zones of automatic air cooling fans. All heating and cooling functions are governed by four separate solid state time proportioning controllers (Eurotherm Type 103, Eurotherm Corp., Reston, VA). In addition, the feed throat region is water jacketed for cooling, to assure proper feeding.

4.3.1 Extruder Instrumention: Instrumentation and monitoring of process parameters are essential in the control of the system. Melt temperature and pressure are monitored through transducers in conjunction with digital readout indicators and/or a chart recorder. An adjustable over-pressure alarm provides an audible signal when a potentially damaging pressure level is reached. Motor load is displayed by an ammeter which contains an automatic overload shutoff. Screw speed is displayed by an analog tachometer. 


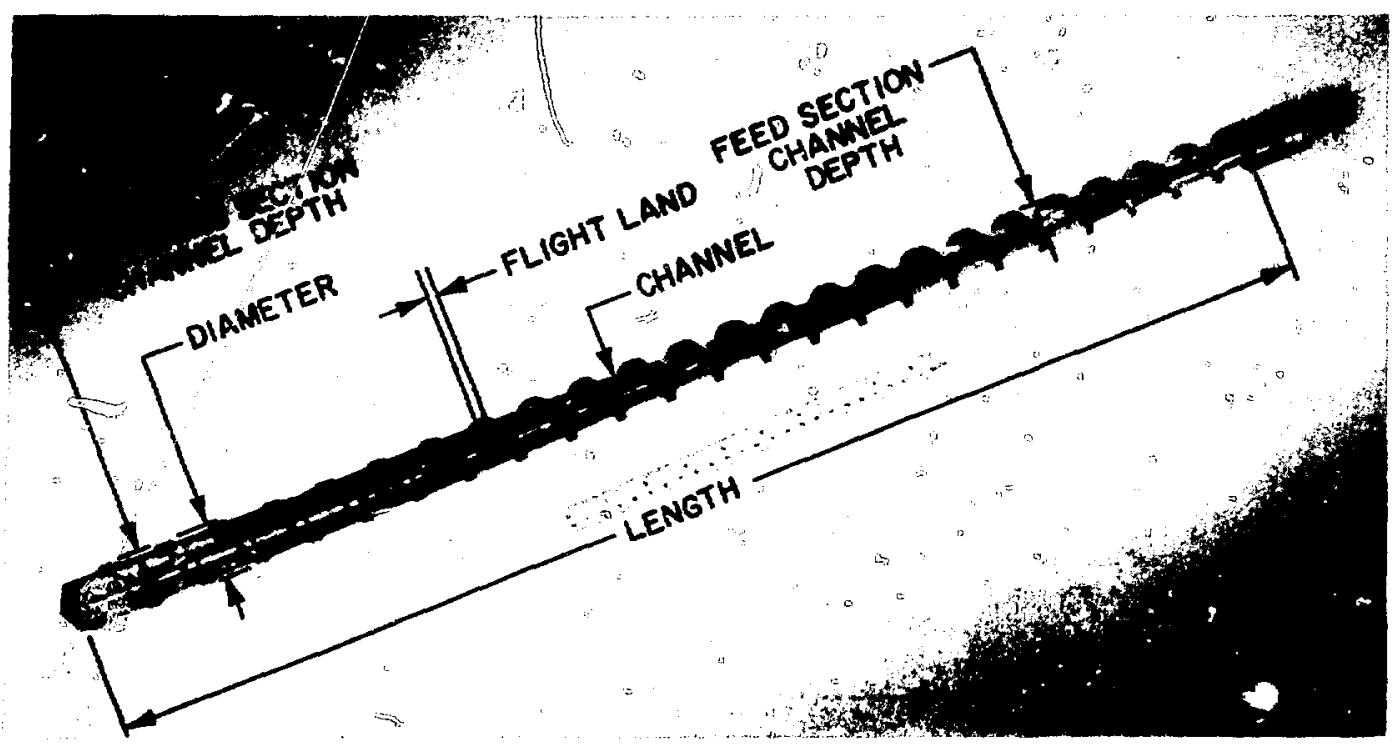

Figure 4.3 Photograph of the 1 1/4" diameter extruiter screw. Materiai enters at the feed section which is located on the right hand side and is conveyed by the helical flights toward the metering section on the left. The decrease in the depth of the channels as the material is conveyed along the screw creates a compressive force.

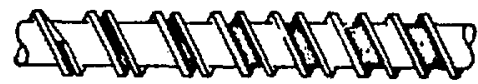

Barrier screw

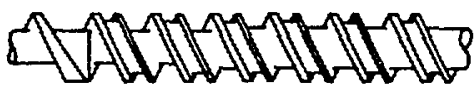

Barr screw

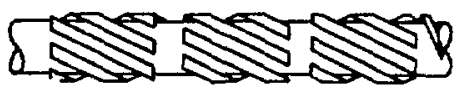

Parallel interrupled mixing flights

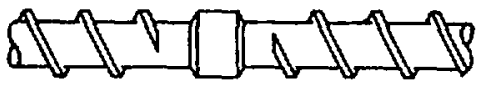

Ring barrier

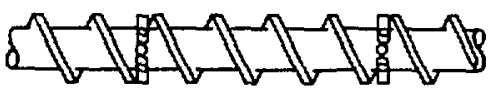

Mixing pins

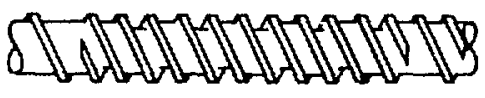

Double wave screw

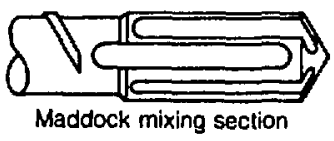

Figure 4.4 Some examples of improved extruder screw designs ${ }^{19}$. 


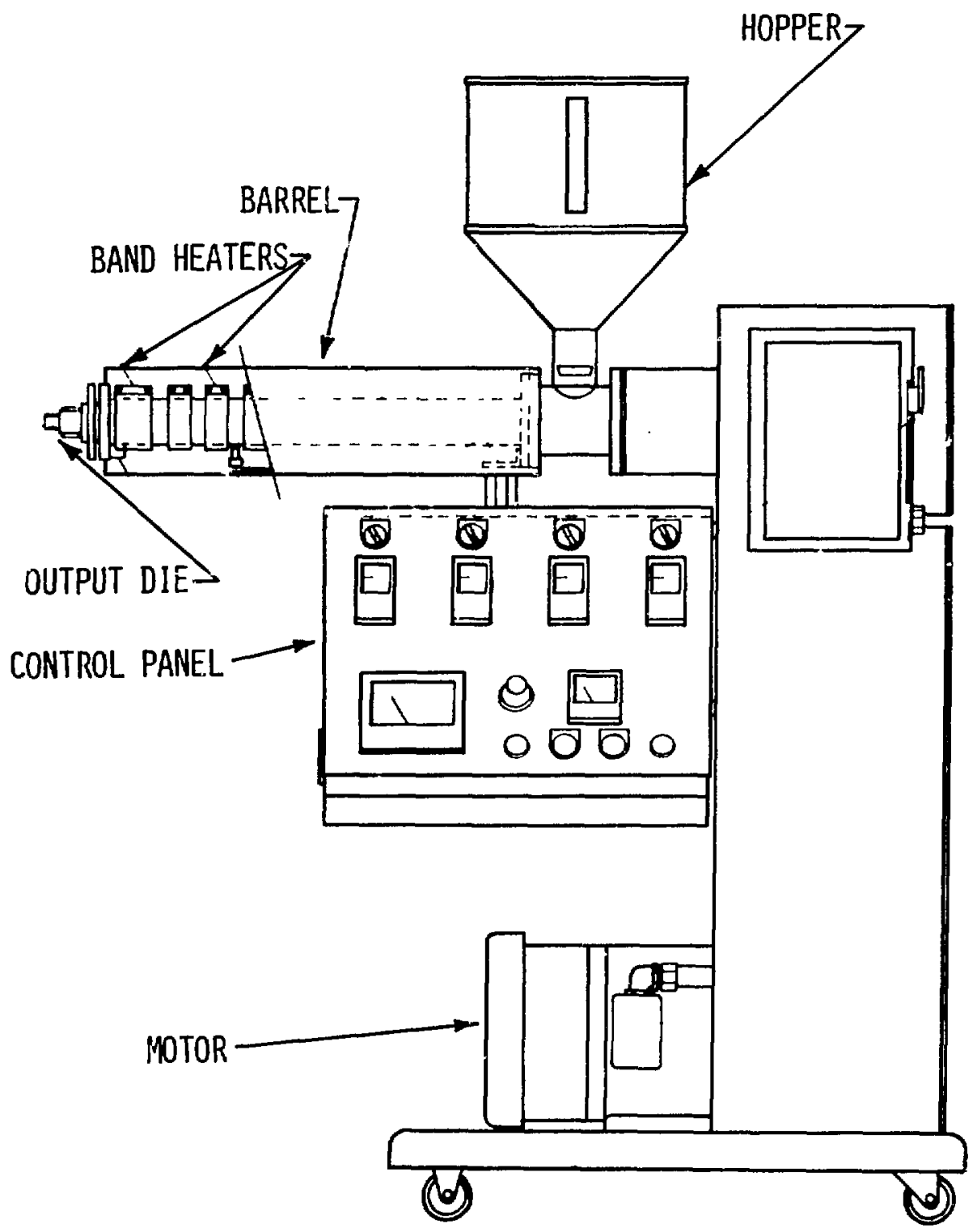

Figure 4.5 Single screw extruder (as-received) used in the production of laboratory scale waste form specimens 19. 
4.3.2 Extruder Modifications: A number of modifications were required on the as-received equipment in order to:

- mold laboratory scale waste form specimens for testing and evaluation.

- enable the precise metering of waste and binder materials.

These changes were performed prior to start-up and on a continuing basis as the need for improvements was indicated. A view of the modified extruder may be seen in Figure 4.6 .

4.3.2.1 Output Die Assembly: An output die assembly and related equipment were custom fabricated at BNL to enable the production of laboratory scale (approximately $5.1 \mathrm{~cm}$ diameter $\times 10.2 \mathrm{~cm}$ in height,) simulated waste forms. The output assembly consists of a tapered reducing coupling, curved transfer tube, sainple cup flange, sample mold, reaction member, and rotating inold supfort stand.

As the molten waste-polyetii? ene mixture exits the extruder it is forced through the reduction coupling which serves to stabilize flow irito the transfer tube. Here the mixture is diverted from a horizontal flow, vertically downward to the sample ilold. The initial design employed a 0.25 inch I.D. stainless steel ture. In the course of process development work this size was found to be overly restrictive and was replaced with a 0.50 inch I.D. tube, enabling greater product throughput and reduction of excessive back pressure especially at higher waste loadings. The temperature of the melt is maintained as it travels through the die by the use of additional electric resistance heaters.

The mixture is then forced under pressure into the sample mold below. As the mold fills it is slowly forced downward against the counter force of the reaction member, so that uniform packing is assured. A steel flange originally provided the mating surface between the transfer tube and mold. This was later replaced with a steel and teflon flange to reduce binding of the mold as it is forced downward, and ease in the removal of the waste form upon cooling.

Sample molds were fabricated from copper pipe and measured 2 inches in diameter by 5.5 inches in height $(5.1 \mathrm{~cm} \times 14.0 \mathrm{~cm})$ to produce a nominal waste form sample size of $2 \times 4$ inches $(5.1 \mathrm{~cm} \times 10.2 \mathrm{~cm})$. The additional height was allotted to allow for waste form shrinkage upon cooling. Copper was chosen for its properties of good thermal conducivity. A later modification introduced the use of disposable sample molds to facilitate easy removal of simulated waste forms and assure a uniformly smooth surface. These polyethylene molds were contained within a copper sleeve which acted as a heat sink and prevented the bonding of the mold and waste form.

4.3.2.2 Feed Assembly: The stock extruder was equipped with an 1100 cubic inch capacity stainless steel feed hopper. Process development scoping studies were performed by pre-weighing and mixing the polyethylene and waste components prior to loading into the hopper. The mixture was then gravity-fed to the extruder feed throat. Several problems surfaced in the use of this static mixing/feeding system such as: 


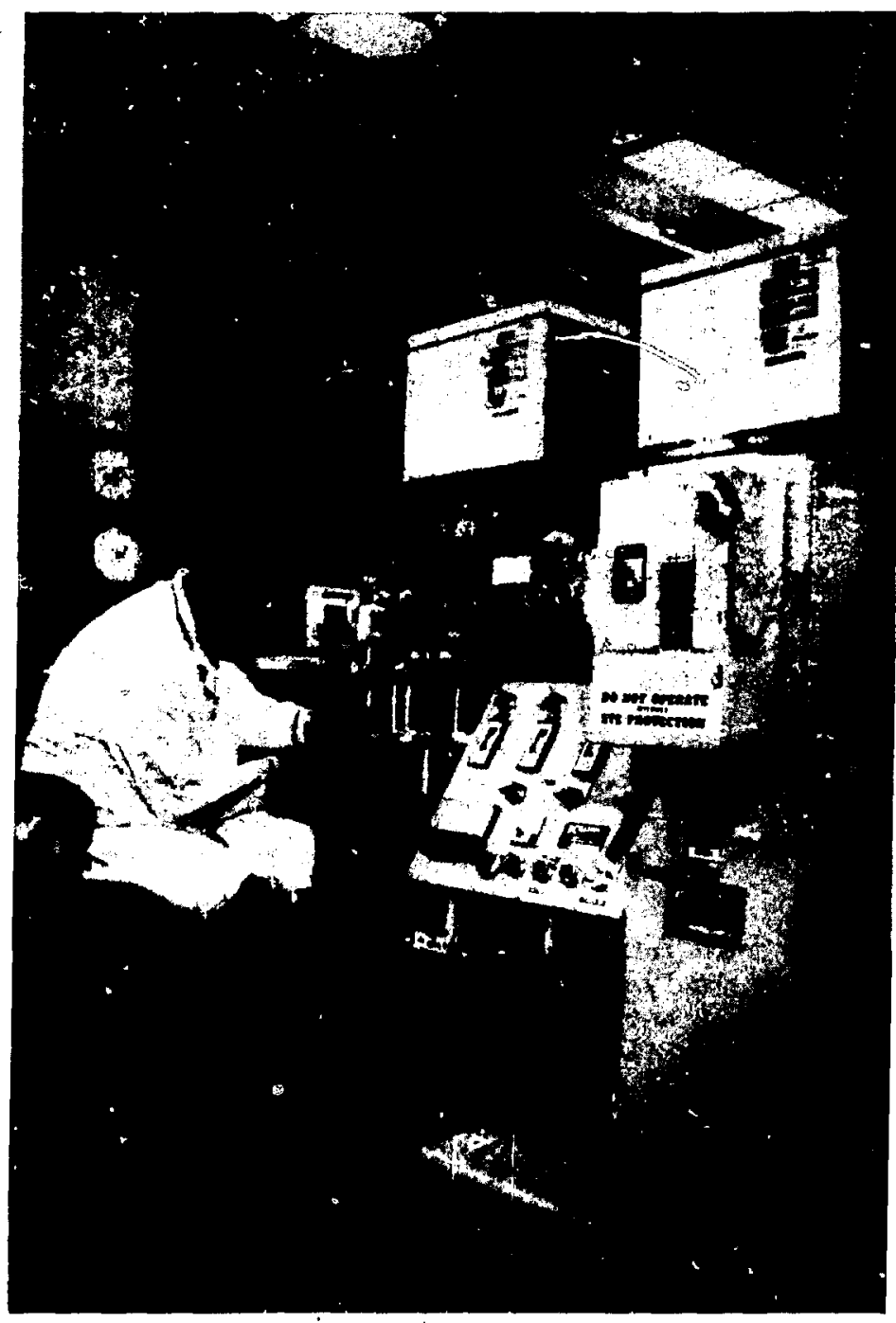

Figure 4.6 Photograph of laboratory-scale single screw extruder upon modification. Note the dual hopper/feeders, and additional instrumentation. Operator is adjusting output die assembly. 
- Segregation of the waste and binder materials - Differences in density and particle size, at times precipitated segregation of the feed constituents leading to problems of homogeneity in the final waste form product.

- "Rat-holing" - A common pheriomenon experienced in the feeding of dry materials in which voids are created by the bridging or packing action of the solids. The net result of this action is increased segregation and discontinuous feeding which ultimately impede homogeneity.

Both of these problems were mitigated by the introduction of a dual hopper/feeder system as described in Section 4.4. In addition, a variable frequency pulsing device was installed to coordinate the delivery of feed materials with extrusion process rates.

\subsection{Dual Hopper/Feeders}

As discussed above, a number of processing difficulties were encountered by use of static pre-mixing and gravity feeding of waste and binder materials. In order to overcome these difficulties a dynamic feed system was used which consisted of two individual Model 300 Accu-Rate hopper/feeders manufactured by Accu-Rate Inc., Whitewater, WI. The hoppers are shown in Figure 4.7 and can be seen installed with the extruder in Figure 4.6 .
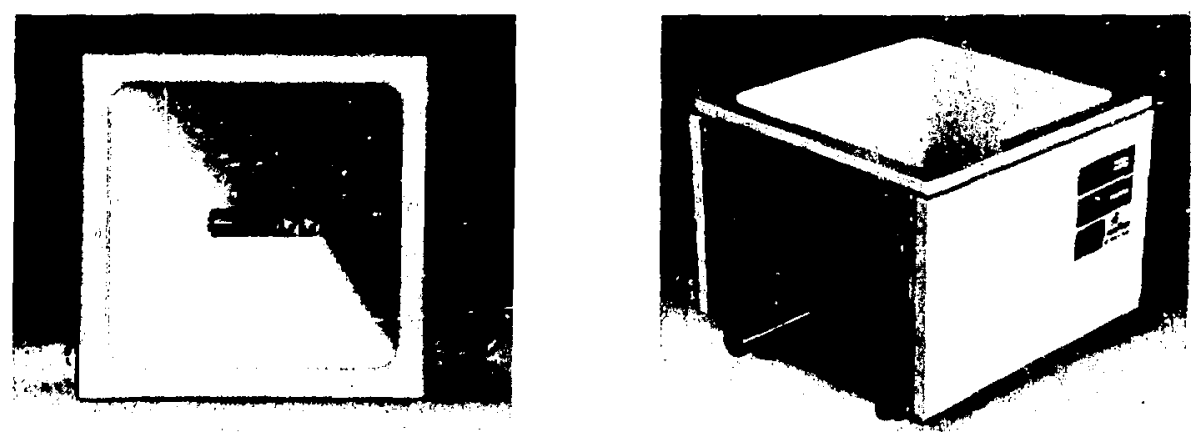

Figure 4.7 Hopper/Feeder assembly used for metering waste and polyethylene to the extruder at a pre-set rate. The top view seen in the photograph on the left shows the helical delivery screw. The digital feed control is seen in the view on the right 20 . 
The hoppers are constructed from flexible $3 / 16^{\prime \prime}(4.8 \mathrm{~mm})$ thick vinyl plastic and have a capacity of 570 cubic inches $\left(9342 \mathrm{~cm}^{3}\right)^{20}$. Two cam operated paddles provide agitation to the hopper by means of a flexing action which distorts the sides. This serves to keep materials flowing downward and assu:'e uninterrupted delivery. At the base of the hopper, material is conveyed horizontally at a constant rate by a rotating helical screw. The helical screw is powered by a $1 / 10$ horsepower d.c. drive motor. Speed is controiled by a digitally set, variable speed SCR. The material is then delivered from each feeder to the extruder feed throat via a tee connection.

Feeder output is dependent upon helix size, helix rotational speed, clrarance between helix and output tube and, to a lesser extent, hopper agitation frequency and amplitude. Each of these factors is, in turn, related to material properties such as density and particle size. After numerous trials with a variety of helix/output combinations, a helix size of 0.5 inch 0.D. $(1.27 \mathrm{~cm})$ and output tube size of 0.75 inch I.D. $(1.91 \mathrm{~cm})$ were selected for optimal delivery of both radwaste and polyethylene.

4.4.1 Calibration of Feed System: Once a given hel ix and output nozzle size are selected, feeder output is controlled by the manipulation of hel ix speed. In order to provide accurate volumetric output data within the operable range of helix speeds, calibration was performed for each feeder and feed material. Calibration of the feeder output delivery allowed precise selection of the quantities of waste and binder materials being introduced to the extruder, thereby regulating the waste to binder ratio in the waste form.

These calibrations were performed by operating the feeder at a given speed setting for periods between one and five minutes, and weighing the output material delivered. The procedure was repeated five times at each speed setting to assess repeatibility and provide data for a statistical error approximation. These data were calculated in terms of the mean weight of the material (in grams) delivered per second $(\mathrm{g} / \mathrm{sec})$. Standard deviation, absolute error and percent error associated with the sample mean at the $95 \%$ confidence interval were calculated. The absolute error, $E$, is defined as 21 :

$$
E= \pm t_{1 / 2 \alpha}, n-1 \frac{5}{n 1 / 2}
$$

where:

$$
\begin{aligned}
& t_{1 / 2 \alpha}=\begin{array}{l}
\text { Column from Student's t-distribution table corresponding with } \\
\text { confidence interval, } \alpha
\end{array} \\
& n-1=\begin{array}{l}
\text { Row from Student's t-distribution table corresponding to } \\
\text { degrees of freedom. }
\end{array} \\
& n \quad=\text { Number of samplings } \\
& s \quad=\text { Standard deviation of sample mean }
\end{aligned}
$$


Output trials were ihen performed throughout the speed range to determine linearity and provide a means of estimating feeder delivery at any speed.

Statistical data for the feeder output calibration of sodium sulfate, boric acid, incinerator ash, ion exchange resins and polyethylene are presented in Appendix $A$, as Tables $A-1$ through $A-5$, respectively. Feeder output data are plotted in terms of screw speed setting (percent of maximum speed) for each of the waste types in Figures A-1 through A-4 and for low-density polyethylene in Figure A-5. Mean values are indicated along with their error bars as calculated by Equation 4.1. Linearity is determined by a least squares linear regression which fits the best straight line through the data. The coefficient of determination, $r^{2}$, indicates the quality of fit achieved by the regression analysis, with 1.0 being the ideal fit. The linear regression line, $r^{2}$, slope and intercept are provided on each plot.

The goodness of fit $\left(r^{2}\right)$ values ranged between 0.983 for incinerator ash and 0.999 for polyethylene. In the case of incinerator ash, linearity was worst in the lowest speed setting. If the linear regression is performed neglecting the data point at 20 percent of maximum set speed, the coefficient of determination improves from an $r^{2}$ of 0.983 to an $r^{2}$ of 0.993 . In actual practice the feeder was operated at mid-range speeds (set speeds between 30 and 60 percent of maximum) where calibration linearity is good.

4.4.2 Extruder Output Calibration: The extruder output rate is defined as the quantity of material which can be processed in any given time. Total outpu: is a function of: 1) machine constraints, e.g. screw size, design and die configuration, 2) material properties, e.g. density, and melt index, and 3) operator controiled parameters, e.g. temperature, screw speed, and feed rate. Determination of the extruder output is important for proper coordination of the feed and processing functions. It can also be used to estimate total processing time for waste form production.

The laboratory scale extruder is rated at a maximum design output of 35 pounds/hour. This specification is given for operation with LDPE and an open front end (no die restriction). In order to more closely replicate actual conditions, a series of extruder output runs were performed with the output die assembly in place. Polyethylene with a melt index of $2.0 \mathrm{~g} / 10$ minutes was employed. The transfer tube measured 0.25 inches I.D. as discussed in Section 4.3.2.1. Use of a higher melt index material and enlarged output transfer tube would lead to increased extruder output.

Extruder parameters for output calibration runs are given in Table A-6. The quantity of material del ivered to the output die in one minute at a constant screw speed was collected and weighed. Output was then calculated in terms of grams/minute and grams/second. The screw speed was then varied between 10 and 80 RPM in increments of 10 RPM, and five replicate trials were performed for each screw speed. The average output rates for each speed al ong with absolute and percent error are reported in Table A-7. These data are plotted as output vs. screw speed in Figure A-6. A linear regression analysis was performed yielding an $r^{2}$ of 0.999 . Maximum output at 80 RPM was 1.7 $\mathrm{g} / \mathrm{sec}$, or $6120 \mathrm{~g} / \mathrm{hour}$ (13.5 1bs./hour). 


\subsection{Processing Parameters}

As discussed in the introduction to Section 4 , a number of processing parameters were identified as being important for the successful implementation of a polyethylene solidification system. In some cases careful manipulation of process controls is required to maintain constant product quality. The operation may be further compl icated by the fact that some parameters such as temperature, pressure and process rate are interrelated. The significance of each processing perameter is discussed in the following sections.

4.5.1 Temperature: Temperature is probably the single most important processing factor for extrusion. Manipulation of this factor influences both processibility and product quality. Temperature has an inverse effect upon melt pressure. This phenomenon is illustrated in Figures $\mathrm{B}-1, \mathrm{~B}-2$ and $\mathrm{B}-3$ (Appendix B). Which plot temperature vs. pressure as a function of screw speed for three types of LDPE's.

From the standpcint of processing, increasing the melt temperature (within a given range), reduces the viscosity of the melt, lowers the pressure and aids extrudibility. Operating at too low a tenperature results in incomplete melting, poor mixing and increased strain on equipment. Too high a temperature may produce a mixture with excessive fluidity. For solidification of radwaste, minimum temperatures are preferable to reduce the possibility of volatilization and decomposition. Temperature is regulated by region or zone and must be adjusted step-wise in a gradual fashion. Excessive temperature variation between zones reduces the effective time in which processing steps may be accomplished. Temperature requirements are also related to process rate. As the extruder speed is increased the temperature must be raised in order to compensate and provide sufficient heat input to the materials.

In regard to product quality, temperature may affect surface appearance and stiffness 17 . Too low a temperature may produce a striated surface and higher temperatures tend to yield a glossy finish. Excessively high temperatures, however, usually create a smeared surface.

Selection of optimal temperatures for radwaste applications, therefore, requires a compromise between such considerations as ease of processibility, compatibility with physicochemical waste properties and the production of a waste form with desirable characteristics.

4.5.2 Pressure: Moderate process pressures (in the range of 500-3000 psi for laboratory-scale extruders) are desirable as they enhance inixing and improve delivery of the material into the mold. Pressures exceeding design limitations can lead to failure of the rupture disc (a pressure relief safety device) and/or the extruder screw.

The melt pressure is dependent upon material properties, process control settings and machine design specifications. Specifically, melt pressure is a function of: 
- Type of polyethylene - LDPEs with lower melt index are more viscous and build up higher melt pressures. This phenomenon is seen by comparing the melt pressures at constant temperature for polyethylenes with melt index values of 2.0 and $55.0 \mathrm{~g} / 10$ minutes in Figure $\mathrm{B}-4$.

- Waste type and loading - The material characteristics of the waste stream such as particle size and compactibility as well as the quantity of waste material incorporated in the mixture may increase the level of pressure developed.

- Melt temperature - Variations in process temperature will affect the pressure, as discussed above and therefore must be considered carefully.

- Process rates - Pressures are directiy related to process rates, as seen in Figures B-1 through B-4. In general, greater pressures are developed at higher screw speeds, which may impose a limitation on maximum process rates.

- Screw design - Process pressure is controlled in part by the magnitude of tha extruder screw compression ratio. Extrusion results can therefore be adjusted by replacement of the screw with one of a different design.

4.5.3 Mixing Method: As discussed in Section 4.3.2.2, the method of mixing waste and binder materials can impact the quality of the waste form. For static pre-mixing, density and particle size differences between materials led to segregation and homogeneity difficulties in the final product. Use of separate feeders provided more precise control of individual constituents, assured continuous delivery to the extruder feed throat and improved mixing.

4.5.4 Feed and Extrusion Rates: The extrusion rate is an operator controlled parameter which affects both the temperatures required for adequate melting and the melt pressure.

From the standpoint of process efficiency and ultimate operational costs, maximum process rates are preferable. However, adverse pressures may result, dictating the use of slower extrusion rates. Feed rates, in turn, are dependent upon the extrusion rate. Excessive feeding results in jamming of delivery tubes and/or feeders. Insufficient feed rates "starve" the extruder and interrupt the continuous flow of materials. By use of a pulsing device to control feeder operation, coordination of feed and extrusion rates was achieved.

4.5.5 Waste Pre-treatment: The detemination of pre-treatment requirements is waste specific. The Taboratory-scale extruder was not equipped with vents to allow vapor pressure to escape, requiring that all waste materials be in a dry condition. Pre-drying of some wastes, e.g. ion exchange resins was therefore necessary. However, many production-scale extruders are equipped with vented sections so that wet wastes could be effectively processed. Other 
pre-treatment steps included particle size characterization in the case of incinerator ash. This step was necessary to el iminate introduction of excessively large solids which might stall the machine or damage the screw.

4.5.6 Power Requirements: The power required for processing is dependent upon material properties and operator control ied parameters such as temperáture and process rate. Current draw is monitored by an ammeter and is directly proportional to the ease of processibility. A highly viscous or dry waste-binder combination results in a large amperage draw (greater than 10 amps for the lab-scale extruder), indicating excessive mechanical stress for the extruder components. Operation under stress conditions reduces the process rate, and adversely influences operating and maintenance costs. The extruder is equipped with a load sensing power shut-off device to guard against damage due to extreme stress conditions.

4.5.7 Solidification Kinetics: The waste-binder mixture was extruded either into copper molds or plastic molds fitted with copper heat sink sleeves. These molds were allowed to air cool to room temperature prior to removal of the monolithic solid waste forms. Cooling times were generally on the order of 30-60 minutes for nominal $2 \times 4$ inch waste forms. Some shrinking usually occurs which enables easy removal of the waste form from the molds.

More rapid cooling techniques such as water immersion baths are sometimes used in the plastics industry, especially for thin strand materials. Use of accelerated cooling by immersion of waste forms in water resulted in uneven shrinkage and the formation of voids. By cooling quickiy, the outer surface of the waste form solidifies rapidly, forming a rigid shell, while the interior remains molten. As the center begins to solidify and contract, it is restricted by the exterior shell, causing deforination and interior voids.

\subsection{Process Development Results}

Optimization of waste-to-binder ratios was conducted for each waste type by varying the process parameters discussed above and selection of polyethylene type best suited for each application. Excessive waste loading increased pressures beyond design limits, increased current draw and occasionaliy stalled the extruder.

Waste form process development results for each waste type investigated are presented in the following sections. Maximum waste loadings are given in terms of dry weight percent of the total waste form weight.

Requisite process parameters for achieving these waste loadings are reported. It should be noted that waste loading results presented in this section are determined on the basis of processibility constraints. Consideration of waste form properties is presented in Section 5. Optimal waste loadings wich reflect a compromise between loading efficiency and waste form pe.'formance are discussed in Section 7. 
4.6.1 Solidification of Sodium Sulfate: Maximum waste form loadings for sodium sulfate solidified in three types of polyethylene are given in Table 4.2. As much as 70 wt\% dry salts were incorporated in both Gulf 1410 and 1409 (melt index of 35 and $55 \mathrm{~g} / 10$ minutes) respectively, corresponding to a wasteto-binder ratio of 2.33. A typical waste form containing 70 wi:\% sodium sulfate is shown in cross-section, along with its constituent elements in Figure 4.8. Note that a smooth, homogeneous distribution of waste is evident throughout the sample. Attempts at waste loadings greater than $70 \mathrm{wt} \% \mathrm{re}-$ sulted in excessively high pressure build-up. Eventually a rupture disc failure occurred when pressures momentarity surged above 7500 psi. Another attempt to extrude an $80 \mathrm{wt \%}$ sodium sulfate mixture resulted in jamming of the screw, requiring disassembly for cleaning.

Process parameters for representative sodium sulfate solidification formulations are presented in Table $\mathrm{C}-1$, Appendix $\mathrm{C}$.

Table 4.2

Maximum Sodium Sulfate Waste Loadings(a)

\begin{tabular}{|c|c|c|c|}
\hline $\begin{array}{l}\text { LDPE } \\
\text { Type } \\
\end{array}$ & $\begin{array}{c}\text { Melt } \\
\text { Index, } \\
\text { g/10 min. }\end{array}$ & $\begin{array}{l}\text { Max. Loading } \\
\text { in LDPE, wt\% }\end{array}$ & $\begin{array}{l}\text { Waste/Binder } \\
\text { Ratio } \\
\end{array}$ \\
\hline $\begin{array}{l}\text { Gulf } \\
1117-B\end{array}$ & 2.0 & 60 & 1.50 \\
\hline $\begin{array}{l}\text { Gulf } \\
1410\end{array}$ & 35.0 & 70 & 2.33 \\
\hline $\begin{array}{l}\text { Gulf } \\
1409\end{array}$ & 55.0 & 70 & 2.33 \\
\hline
\end{tabular}

(a) Determined on the basis of processibility constraints.

4.6.2 Solidification of Boric Acid: Maximum waste loadings for boric acid solidified in three types of polyethyl ene are given in Table 4.3. Waste loadings of $50 \mathrm{wt} \%$ boric acid corresponding to a waste to binder ratio of 1.0 were achieved using Gulf 1.409 (melt index of $55 \mathrm{~g} / 10$ minutes).

Processing of this waste complicated by the fact that orthoboric acid 1 iberates water vapor in its transition to metaboric acid at temperatures above $170^{\circ} \mathrm{C}$. In an un-vented extruder this vapor becomes trapped, creating undesirable pressure surges and waste forms which contain voids due to gas entrapment. This temperature constraint was most evident when processing Gulf 1i17-B with a melt index of $2.0 \mathrm{~g} / 10$ minutes. A maximum of $30 \mathrm{wt} \%$ boric acid 


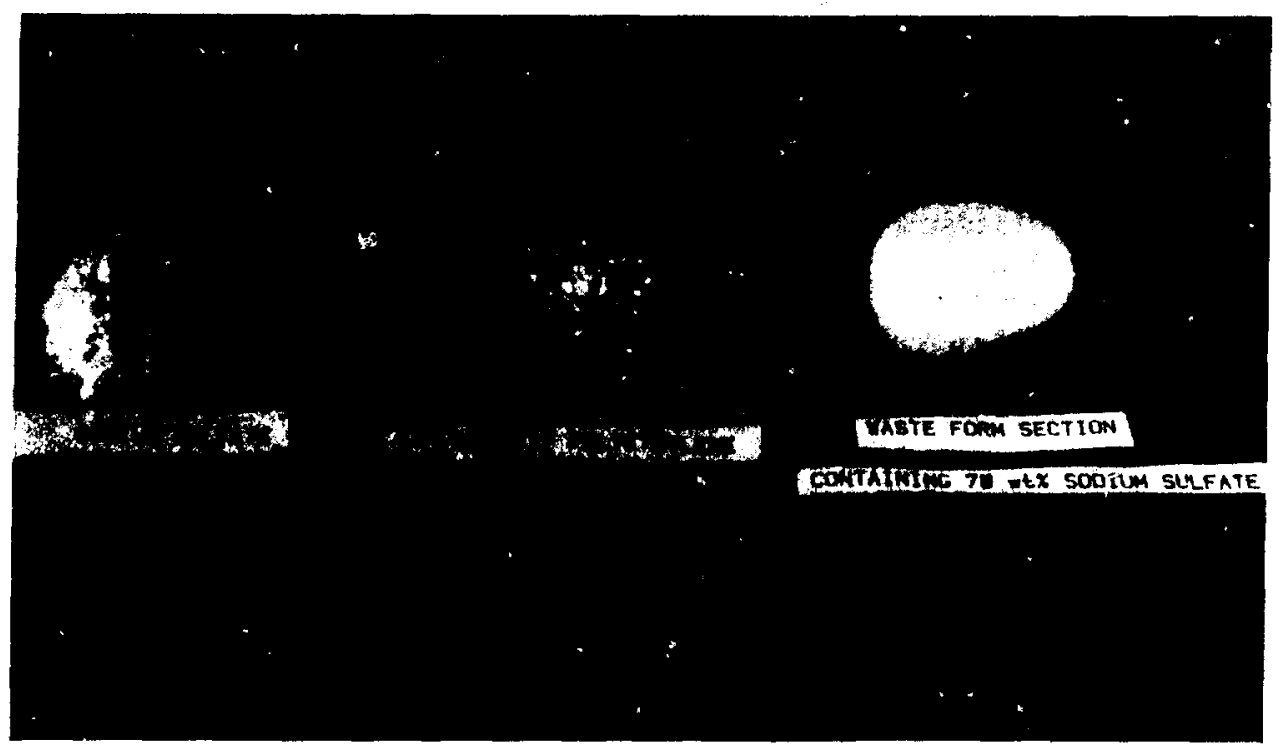

Figure 4.8 Cross-sectional view of a polyethylene waste form containing $70 \mathrm{wt} \%$ sodium sulfate, along with formulational constitutents. 
Table 4.3

Maximum Boric Acid Waste Loadings(a)

$\begin{array}{lccc}\begin{array}{l}\text { LDPE } \\ \text { Iype }\end{array} & \begin{array}{c}\text { Meit } \\ \text { Index, } \\ \text { g/10 min. }\end{array} & \begin{array}{c}\text { Max. Loading } \\ \text { in LDPE, wt\% }\end{array} & \begin{array}{c}\text { Waste/Binder } \\ \text { Ratio }\end{array} \\ \begin{array}{l}\text { Gulf } \\ \text { 1117-B }\end{array} & 2.0 & 30 & 0.43 \\ \begin{array}{l}\text { Gulf } \\ 1410\end{array} & 35.0 & 40 & 0.67 \\ \begin{array}{l}\text { Gulf } \\ 1409\end{array} & 55.0 & 50 & 1.0\end{array}$

(a) Determined on the basis of processibility constraints.

salts were incorporated using this polyethylene due to its high melt viscosity. The viscous mixture could not be compensated by additional heat input as was done in the case of sodium sulfate where melt temperatures were on the order of $195^{\circ} \mathrm{C}$. Use of higher melt index LDPEs enabled increased waste loading, as these plastics flow more readily at reduced temperatures.

Operating at minimal temperatures however, tended to yield a rough surface, as discussed in Section 4.5.1. Optimal processing temperatures were chiusen to balance these considerations. Process parameters for representative boric acid solidification formulations are given in Table C-2, Appendix C.

4.6.3 Solidification of Incinerator Ash: Sol idification of incinerator ash was performed using two polyethylenes manufactured by Gulf 0 il Chemicals (1117-B and 1409) and one by Eastman Chemicals Inc. (C-17). A maximum of 40 wt\% ash was incorporated with both Gulf 1409 and Eastman C-14 binders as shown in Table 4.4. A representat ive incinerator ash waste form which contains 10 wt\% ash is depicted in cross-section in Figure 4.9 , along with the waste and binder materials. The ash is well incorporated giving the sample a black color with specks of light gray ash evenly distributed throughout. Specimens which contain 40 wt\% ash were not photographed but have much the same visible appearance as the waste form section shown in Figure 4.9.

Eastman $\mathrm{C}-17$ has a melt index of $20.0 \mathrm{~g} / 10$ minutes and behaves in much the same way as the Gulf 1410 with a melt index of $35.0 \mathrm{~g} / 10$ minutes. It's density $\left(0.917 \mathrm{~g} / \mathrm{cm}^{3}\right)$ and molecular weight $(19,000)$ are lower than those of Gulf 1410 (density $=0.924 \mathrm{~g} / \mathrm{cm}^{3}$, molecular weight $=55,000$ ) which characterize this material as a non-emulsifiabale wax. As such, it forms a solid 


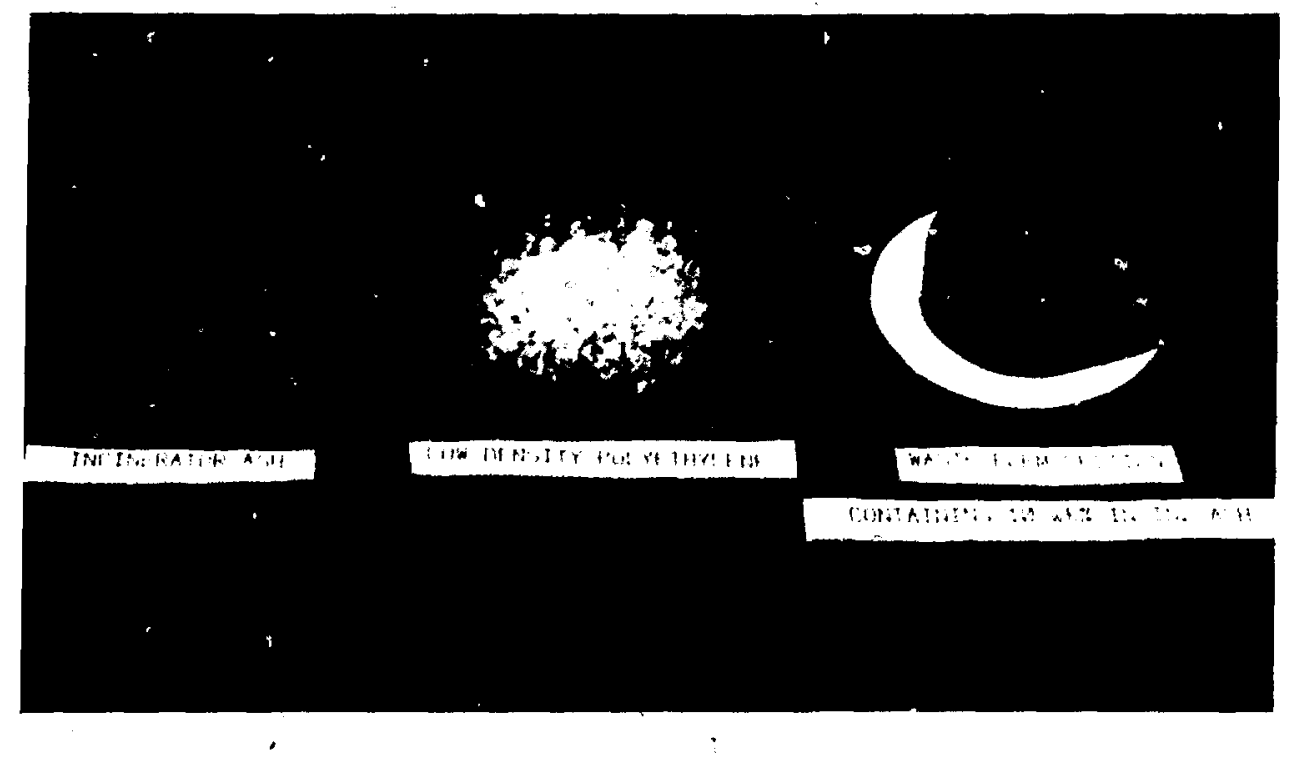

Figure 4.9 Cross-sectional view of a polyethylene waste form containing $10 \mathrm{wt} \%$ incinerator ash, along with formulational constitutents. 
Table 4.4

Maximum Incinerator Ash Waste Loadings(a)

$\begin{array}{lccc}\begin{array}{l}\text { LDPE } \\ \text { Type }\end{array} & \begin{array}{c}\text { Melt Index, } \\ \text { g/10 min. }\end{array} & \begin{array}{c}\text { Max. Loading } \\ \text { in LDPE, wt\% }\end{array} & \begin{array}{c}\text { Waste/Binder } \\ \text { Ratio }\end{array} \\ \begin{array}{l}\text { Gulf } \\ 1117-B\end{array} & 2.0 & 25 & 0.33 \\ \begin{array}{l}\text { Eastman } \\ \text { C-17 }\end{array} & 20.0 & 40 & 0.67 \\ \text { Gulf } & 55.0 & & \\ 1409 & & 40 & 0.67\end{array}$

(a) Determined on the basis of processibility constraints.

which is softer and more susceptible to impact damage. Processing with Gulf $1117-B$ (melt index $=2.0 \mathrm{~g} / 10$ minutes) required much higher temperatures, attributable to the fact that the polyethylene-ash combination formed an extremely thick, dry mixture. Use of the lower melt index Gulf 1409 enabled a loading improvement of $15 \mathrm{wt} \%$. Attempts at waste loadings greater than 40 wt\% resulted in plugging of the output transfer tube.

Process parameters for representative incinerator ash solidification formulations are presented in Table $\mathrm{C}-3$, Appendix $\mathrm{C}$.

4.6.4 Solidification of Ion Exchange Resins: Ion exchange resins were solidified with Gulf $1117-B, 1410$ and 1409 polyethylenes. Maximum waste loadings for each of these binders were 50, 60 and 65 wt\%, respectiveiy as shown in Table 4.5 .

Mixed bed ion exchange resin beads were oven dried prior to processing, as discussed in Section 4.1. Incomplete drying caused product foaming due to vapor build up. Processing of resin beads differed from the other waste streams in that particle size was significantly larger $(0.5-1.0 \mathrm{~mm}$ in diameter). The beads were well mixed with polyethylene by the action of the extruder but were retained as discrete suspended particles in the melt and in the solidified waste form. This can be seen in the photograph of an ion exchange resin waste form section containing 50 wt\% waste, included as Figure 4.10. Sodium sulfate, boric acid and incinerator ash on the other hand, are all characterized by a fine powder and were incorporated in a homogenous fashion in which individual particles were indistinguishable in the waste form (see Figures 4.8 and 4.9 ). 


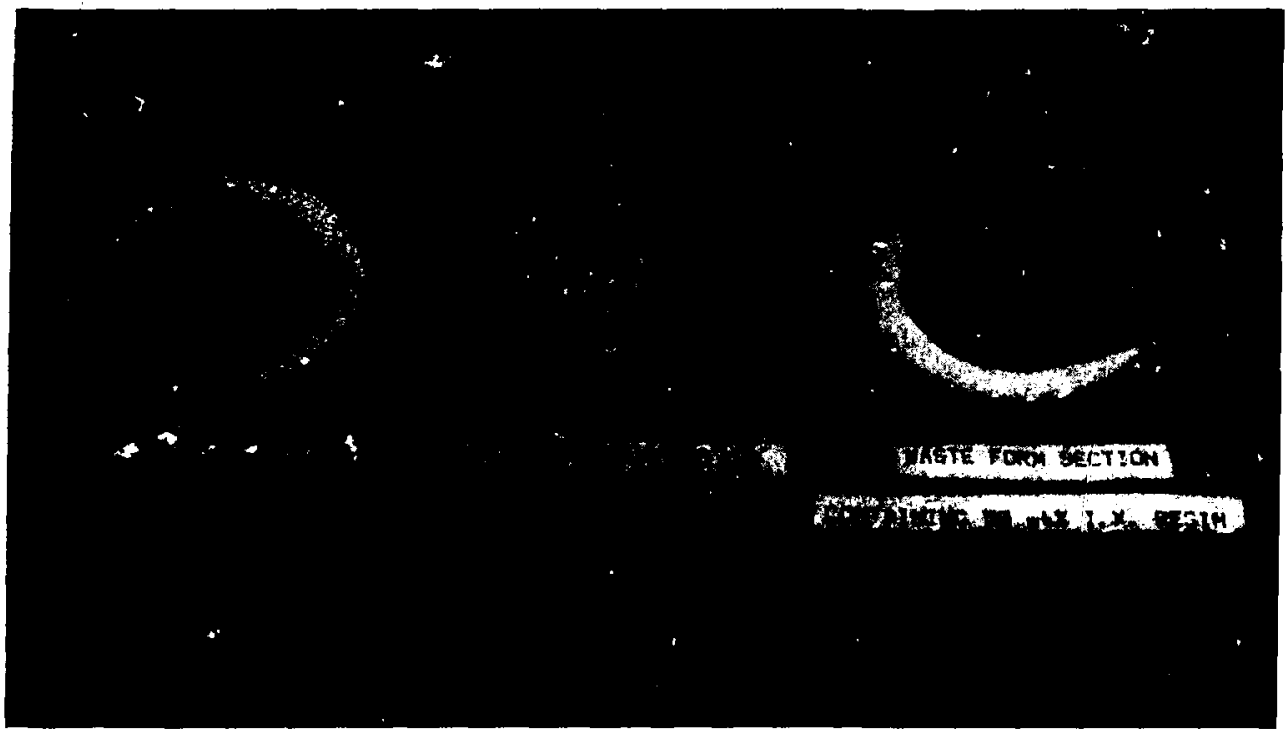

Figure 4.10 Cross-sectional view of a polyethylene waste form containing $50 \mathrm{wt} \%$ ion exchange resins, along with formulational constitutents. 


\section{Table 4.5}

Maximum Ion Exchange Resin Waste Loadings(a)

$\begin{array}{lccc}\begin{array}{l}\text { LDPE } \\ \text { Type }\end{array} & \begin{array}{c}\text { Melt Index, } \\ \text { g/10 min. }\end{array} & \begin{array}{c}\text { Max. Loading } \\ \text { in LDPE, wt\% }\end{array} & \begin{array}{c}\text { Waste/Binder } \\ \text { Ratio }\end{array} \\ \begin{array}{l}\text { Gulf } \\ 1117-B\end{array} & 2.0 & 50 & 1.0 \\ \begin{array}{l}\text { Gulf } \\ 1410\end{array} & 35.0 & 60 & 1.50 \\ \text { Gulf } & 55.0 & & \\ 1409 & & 65 & 1.86\end{array}$

(a) Determined on the basis of processibility constraints.

The impact of resin bead particle size was observed as increased waste loadings were attempted. Beyond 50 wt\% ion exchange resins, plugging of the 0.25 inch I.D. output transfer tube occurred. As discussed in Section 4.3.2.1, its replacement with a larger tube $(0.50$ inch I.D.) overcame processing difficulties, and allowed additional resin waste to be incorporated.

Process parameters for representative ion exchange resin waste form formulations are given in Table $\mathrm{C}-4$, Appendix $\mathrm{C}$. 


\section{WASTE FORM PROPERTY EVALUATION STUDIES}

\subsection{Introduction}

A critical factor in the effective long term performance of shallow land burial sites is the maintenance of a stable trench. Experience has shown that slumping or collapse of the trench can lead to the release of contained radionuclides by dispersion or accelerated leaching. In recent years increased emphasis has been placed upon waste form performance as a major component for the assurance of burial site stability. Thus a physicochemical data base of relevant waste form properties has been developed to help predict potential behavior in a burial environment. These data were generated through the application of a series of standardized property tests for simulated laboratory scale waste form specimens, based upon preliminary waste form evaluation criteria reported in the Letter Report to DOE22. Selected tests as listed below are also included in the NRC's Branch Technical Position on Waste Form 23 , so that results can be easily compared with materials being tested for compliance with 10 CFR 61 stability requirements:

- Water Immersion (90 days)

- Deformation Under Compressive Load (ASTM D-621)

- Thermal Cycling (ASTM B-553)

- Leaching (ANS 16.1, 90 days)

It should be noted that it was not the intent of this program to qualify polyethylene waste forms for commercial disposal. Additional testing (including biological and radiation stability tests) which were beyond the scope of this investigation would be required for NRC licensing.

The tests outlined above have been applied for polyethylene waste fomn containing each of the waste types investigated at varying levels of waste loadings. Testing procedures and results are reported in this section.

\subsection{Water Immersion Testing}

Waste forms disposed by shallow land burial may potentially encounter periods of exposure to aqueous conditions in the form of percolate and/or ground water. Depending upon the composition of the contained waste, these conditions may cause swelling, cracking, dissolution or exfoliation of the waste form structure. Waste form degradation, in turn, may accelerate container failure, increase radionucl ide migration and contribute toward deterioration of the trench. The failure of sodium sulfate and ion exchange resin waste forms soljdified in hydraulic cement, when exposed to water has been well documented 24,25 . 
Water immersion tests were performed on representative, simulated waste forms for a period of 90 days. Waste form specimens measured a nominal 2 inches $(5.1 \mathrm{~cm})$ in diameter by 4 inches $(10.2 \mathrm{~cm})$ in height. Dimensional changes, as well as gross failure in structural integrity, were recorded at the end of 90 days. Results of water immersion testing are summarized in Table 5.1 .

Boric acid waste forms containing between 35 and $50 \mathrm{wt} \%$ waste and sodium sulfate waste forms containing $60 \mathrm{wt} \%$ waste or less demonstrated little or no effect due to water immersion. Swelling for these specimens was measured at $\leq 0.2 \%$. Waste forms containing $70 \mathrm{wt} \%$ sodium sulfate exhibited a small degree of swelling (between 0.7 and 1.7\%). Incinerator ash waste forms incoiporating 25 and 35 wt\% waste demonstrated swelling of 0.5 and $2.0 \%$, respectively.

Ion exchange resin waste forms, as expected, were the most susceptibie to swelling in water immersion testing. As dry resin beads sorb water they expand and create tensile stresses within the waste form. Since polyethylene is a relatively ductile'material it is better able to withstand these stresses than more brittle materials such as hydraulic cement.

For polyethylene waste forms containing up to $30 \mathrm{wt} \%$ dry ion exchange resins, overall swelling was $\leq 1.3 \%$. For higher waste loadings results varied with the type of polyethylene employed. Specimens formulated from Gulf 1117-B containing 50 wt\% resins, experienced a moderate degree of swelling $(8.7 \%)$, but no deterioration in structural integrity was observed. Those formulated from Gulf 1410 which contained 50 wt\% resin swelled severely and cracked in several places. Waste forms containing 60 and $65 \mathrm{wt} \%$ ion exchange resins formulated from Gulf 1410 and Gulf 1409 al so failed catastrophically due to the swelling resin beads.

It can be concluded, therefore, that the behavior of ion exchange resin waste forms in an aqueous environment is dependent upon the quantity of waste incorporated and the type of polyethylene binder used. Waste forms containing as much as $30 \mathrm{wt} \%$ resin loading were able to withstand the tensile stresses with minimal distortion. In similar studies previously performed at BNL, cement waste forms containing more than $13 \mathrm{wt} \%$ ion exchange resins suffered severe cracking during immersion testing25. Normalizing for the differences in waste form density, $30 \mathrm{wt} \%$ resin loading in polyethylene equates to 23.1 vol $\%$, while 13 wt $\%$ resin loading in cement is equivalent to 17.5 vol $\%$, for a net improvement of $32 \%$ in the loading efficiency for polyethylene.

Those polyethylene waste forms formulated from the lower melt index LDPE (Gulf 1117-B) demonstrated a greater resistance to swelling than the higher melt index materials (Gulf 1410 and 1409). This phenomena can be explained by the fact that tensile strength decreases as the filuidity of the melt (melt index) increases. The tensile strength for these polyethylenes are reported as 2000 psi (Gulf 1117-B), 1700 psi (Gulf 1410) and 1600 psi (Gulf 1409) for corresponding melt index values of $2.0,35.0$ and $55.0 \mathrm{~g} / 10$ minutes 26 . 
Table 5.1

Water Immersion Test Results for Polyethylene Waste Forms(a)

\begin{tabular}{|c|c|c|c|}
\hline $\begin{array}{l}\text { Waste } \\
\text { Type }\end{array}$ & $\begin{array}{c}\text { Waste } \\
\text { Loading, wt\% }\end{array}$ & $\begin{array}{l}\text { LDPE } \\
\text { Type }\end{array}$ & $\begin{array}{c}\text { Swelling, } \\
\% \\
\end{array}$ \\
\hline $\begin{array}{l}\text { Sodium } \\
\text { Sulfate }\end{array}$ & $\begin{array}{l}54 \\
60 \\
70 \\
70\end{array}$ & $\begin{array}{l}1409 \\
1409 \\
1409 \\
1410\end{array}$ & $\begin{array}{l}0.0 \\
0.2 \\
1.7 \\
0.7\end{array}$ \\
\hline Boric Acid & $\begin{array}{l}35 \\
40 \\
40 \\
45 \\
50\end{array}$ & $\begin{array}{l}1410 \\
1410 \\
1409 \\
1409 \\
1409\end{array}$ & $\begin{array}{l}0.2 \\
0.0 \\
0.0 \\
0.0 \\
0.0\end{array}$ \\
\hline $\begin{array}{l}\text { Incinerator } \\
\text { Ash }\end{array}$ & $\begin{array}{l}25 \\
35\end{array}$ & $\begin{array}{l}1409 \\
1409\end{array}$ & $\begin{array}{l}0.5 \\
2.0\end{array}$ \\
\hline $\begin{array}{l}\text { Ion } \\
\text { Exchange } \\
\text { Resin }\end{array}$ & $\begin{array}{l}20 \\
28 \\
30 \\
50 \\
50 \\
60 \\
60 \\
65\end{array}$ & $\begin{array}{l}1409 \\
1410 \\
1409 \\
1117-B \\
1410 \\
1410 \\
1409 \\
1409\end{array}$ & $\begin{array}{l}0.0 \\
0.7 \\
1.3 \\
8.7 \\
\text { S.C. (b) } \\
\text { S.C. } \\
\text { S.C. } \\
\text { S.C. }\end{array}$ \\
\hline
\end{tabular}

(a) Measured as $\Delta$ length/original iength

(b) S.C.: severe cracking 


\subsection{Deformation Under Compressive Load}

Since polyethylene is a non-rigid plastic with no discrete compressive yield strength point, standard compressive strength testing according to ASTM C-3927 is not applicable. As seen in Figure 5.1 which plots stress (load per unit area) versus strain (ratio of the change in length to the original length), the waste form specimen under test continues to deform with increasing load, and no failure point is evident. In order to determine the effects of a compressive load on polyethylene waste form integrity, specimens were tested in accordance with ASTM D-621, "Standard Method of Test for Deformation of Plastics Under Load"28.

ASTM D-621 specifies a constant compressive load of 100 psi for a period of three hours. This compares with a minimum compressive strength of 50 psi as outlined in the NRC Branch Technical Position on Waste Form ${ }^{23}$. A standard compression test machine was modified to comply with the $0-621$ test procedures, and is pictured in Figure 5.2. The apparatus consists of a freemoving 100 pound load assembly and a dial indicator to measure deformation. Waste form specimens were machined from their original dimensions of $2 \times 4$ inches $(5.1 \times 10.2 \mathrm{~cm})$ to a nominal size of 1.13 inches $(2.87 \mathrm{~cm})$ in diameter by 0.5 inches $(1.27 \mathrm{~cm})$ in height, as specified. This dirnension enables a load of 100 psi to be applied to the samples. Specimens were stored in a desicator until tested to minimize the effects of moisture. Testing was performed at ambient temperature conditions $\left(20 \pm 2^{\circ} \mathrm{C}\right)$.

Deformation of waste form specimens was calculated as follows:

$$
\text { Deformation, } \%=\left(H_{0}-H_{1} / H_{0}\right) \times 100 \quad \text { (Eqn. 5.1) }
$$

where:

$H_{0}=$ original specimen height (thickness)

$H_{1}=$ specimen thickness after 3 hours under 100 psi load

One and one-half hours after specimens were removed from the tester, their dimensions were measured again. The extent that specimens recovered to their original dimensions was calculated by:

$$
\text { Recovery, } \%=\left(H_{2}-H_{1}\right) /\left(H_{0}-H_{1}\right) \times 100 \quad \text { (Eqn. 5.2) }
$$

where:

$\mathrm{H}_{2}=$ specimen thickness 1.5 hours after load removal

The average results for deformation testing of three replicates are given in Table 5.2. These data are represented in graphical form as the unshaded bars in the histogram, included as Figure 5.3 . 


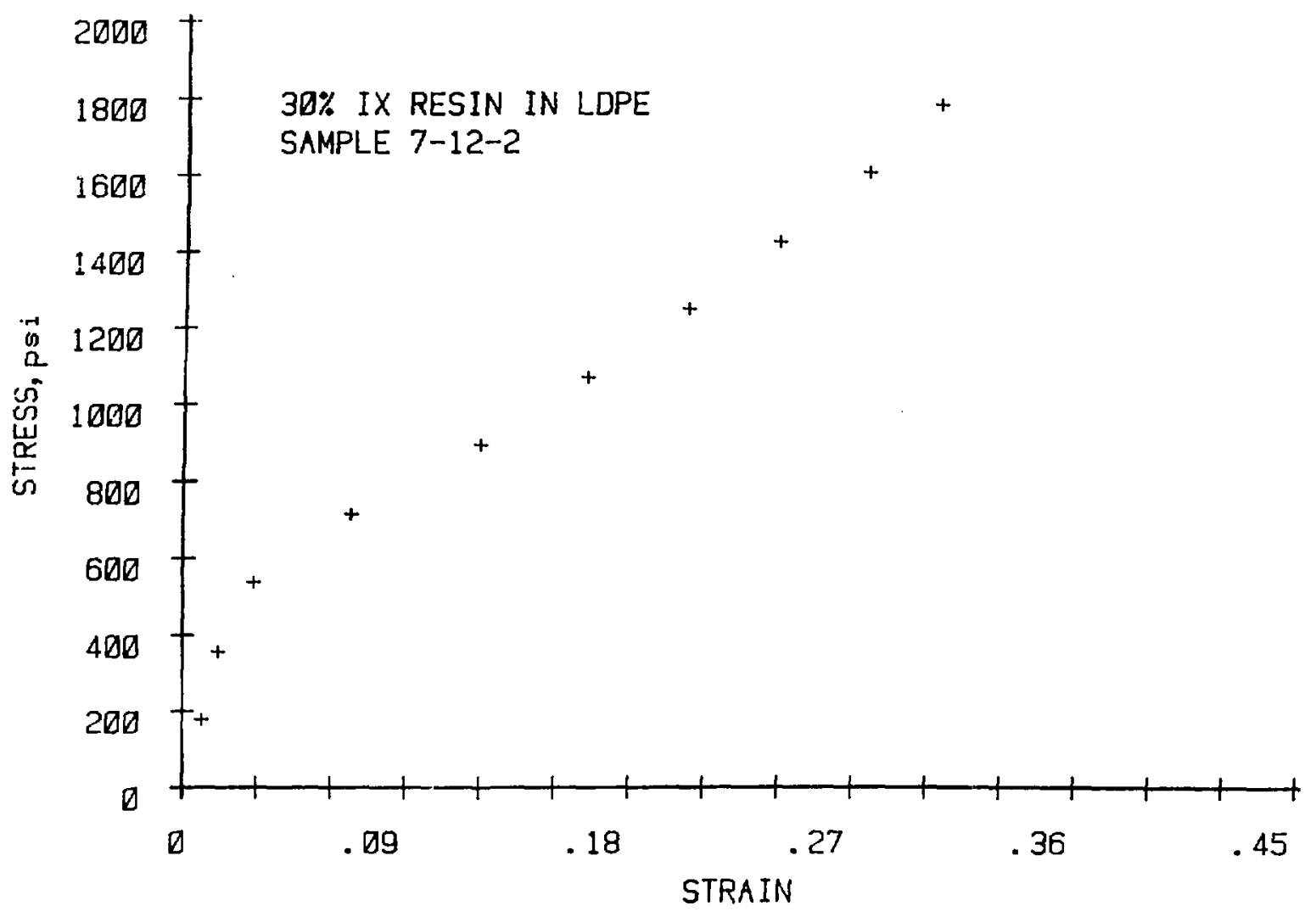

Figure 5.1 Stress strain curve for LDPE waste form incorporating 30 wt\% ion exchange resins. Note that no discernable yield point is evident. 


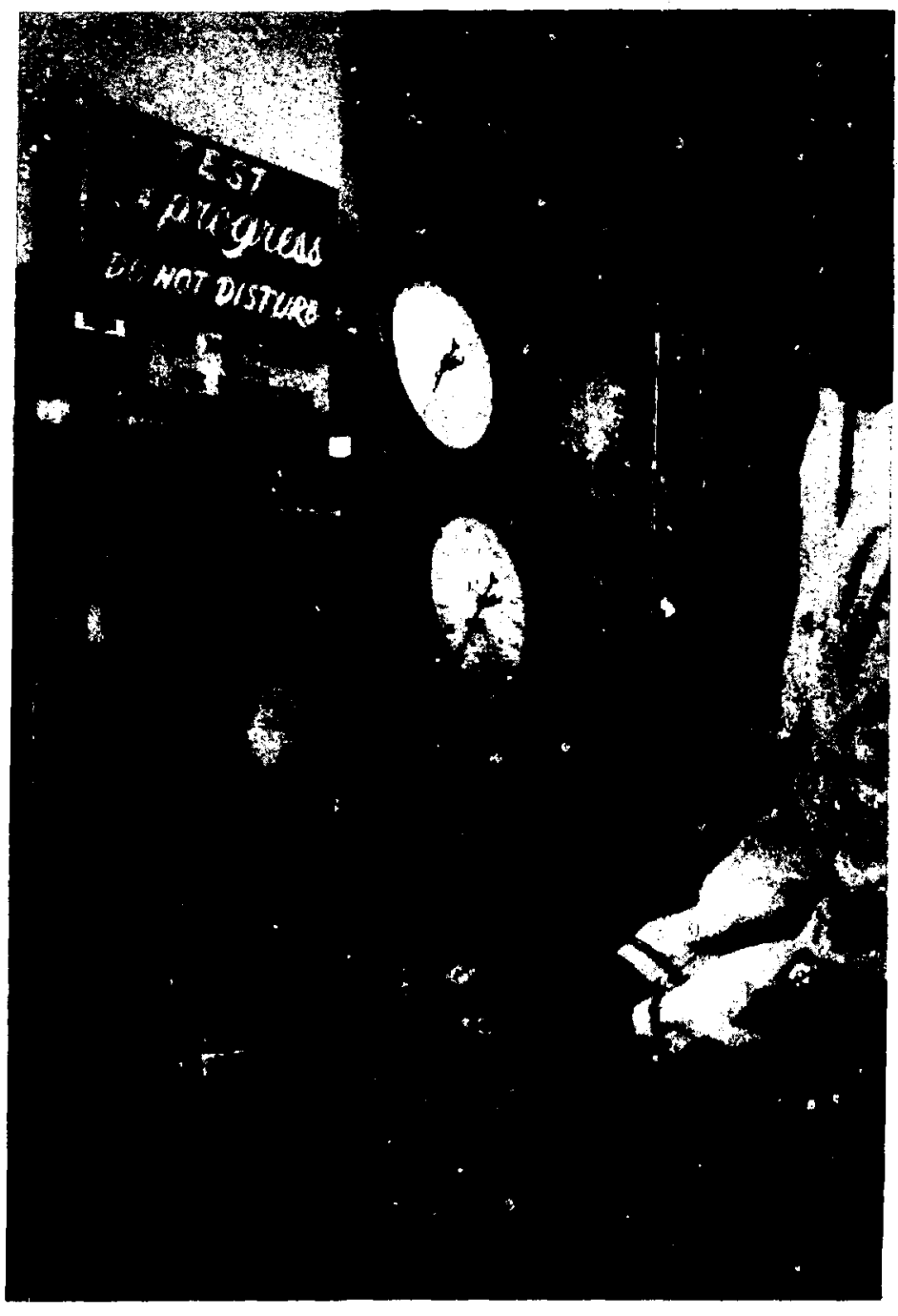

Figure 5.2 Photograph of compression test machine modified to perform deformation testing according to ASTM D-621. 
Results of Waste Form Deformation Testing Under 100 psi
Compressive Load $(a),(b)$

\begin{tabular}{|c|c|c|c|c|c|c|}
\hline $\begin{array}{c}\text { Test } \\
\text { Spec imen } \\
\text { No. } \\
\end{array}$ & $\begin{array}{l}\text { Waste } \\
\text { Type } \\
\end{array}$ & $\begin{array}{c}\text { Waste } \\
\text { Loading, wt\% } \\
\end{array}$ & $\begin{array}{l}\text { LDPE } \\
\text { Iype }\end{array}$ & $\begin{array}{l}\text { Original } \\
\text { Thickness, } \\
\text { cm. } \\
\end{array}$ & $\begin{array}{c}\text { Deformation, } \\
\frac{\%}{6}\end{array}$ & $\begin{array}{c}\text { Recovery, } \\
\% \\
\end{array}$ \\
\hline $1-3$ & $\mathrm{Na}_{2} \mathrm{SO}_{4}$ & 54 & 1409 & 1.27 & 0.21 & 100 \\
\hline $6-8$ & $\mathrm{Na}_{2} \mathrm{SO}_{4}$ & 60 & 1409 & 1.27 & 0.15 & 100 \\
\hline $11-13$ & $\mathrm{Na}_{2} \mathrm{SO}_{4}$ & 70 & 1409 & 1.28 & 0.14 & 100 \\
\hline $16-18$ & $\mathrm{H}_{3} \mathrm{BO}_{3}$ & 30 & 1410 & 1.28 & 0.16 & 99.8 \\
\hline $2 z-23$ & $\mathrm{H}_{3} \mathrm{BO}_{3}$ & 40 & 1410 & $1.27(c)$ & $0.11(c)$ & $99.3(c)$ \\
\hline $26-28$ & I.X. Resin & 28 & 1410 & 1.27 & 0.24 & 99.5 \\
\hline $31-33$ & I.X. Resin & 50 & 1410 & 1.27 & 0.26 & 100 \\
\hline $36-38$ & 1.X. Resin & 60 & 1410 & 1.26 & 0.16 & 99.8 \\
\hline $41-43$ & I.X. Resin & 65 & 1410 & 1.27 & 0.31 & 99.9 \\
\hline $46-48$ & I.X. Resin & 60 & 1409 & 1.27 & 0.22 & 99.9 \\
\hline $51-53$ & I.X. Resin & 50 & 1117-B & 1.27 & 0.36 & 99.6 \\
\hline $56-58$ & Ash & 20 & 1409 & 1.28 & 0.18 & 99.5 \\
\hline $61-63$ & Ash & 40 & 1409 & 1.24 & 0.08 & 99.7 \\
\hline $66-68$ & Ash & 40 & $C-17$ & 1.27 & 0.18 & 99.8 \\
\hline
\end{tabular}

a) Performed in accordance with ASTM D-621

b) Results reflect average values for 3 replicates, except where indicated

c) Based on 2 replicate specimens 
Results of defonmation testing indicate that polyethylene can easily withstand loads up to 100 psi with no effect on waste form integrity. In addition, none of the waste form samples tested exceeded a total deformation of $0.36 \%$ when subjected to these loads. Such minor distortion in waste form dimensions is not expected to disturb the burial trench structure in the event of a container failure. In general, the incorporation of waste materials serves to strengthen the waste form structure. Deformation decreased with additional waste incorporation for most specimens. Variability of the results between samples was slight $(0.28 \%$ deformation separated minimum and maximum values) indicating littie dependence upon waste or polyethylene types. Polyethylene has the additional advantage of possessing "structural memory" so that it tends to return to its original dimensions when the compressive load is released. All samples tested returned to at least $99 \%$ of their original shape within 1.5 nours.

\subsection{Themal Cycle Testing}

In order to determine the effects of extreme temperature environments wich waste forms may experience during storage, transportation or burial, thermal cycle testing was performed. Testing was conducted in accordance with the procedures of ASTM B-553, "Thermal Cycling of Electroplated Plastics" 29 , with the exception of several modifications as per the recommendations outlined in NRC's "Branch Technical Position on Waste Forms"23.

Cycling of waste form specimens was performed using a Model T6C environmental chamber, manufactured by Tenney Engineering, Inc., Union, NJ. The chamber, as pictured in Figure 5.4 has a capacity of 6 cubic feet. It is capable of achieving temperature ranges between $-73^{\circ} \mathrm{C}$ and $+200^{\circ} \mathrm{C}$, with a control tolerance of $\pm 0.3^{\circ} \mathrm{C}$. Temperature settings and duration are microprocessor controlled. Heating and cooling functions are maintained by conditioned air flow.

Waste form specimens tested were replicates of those employed for deformation testing. As such, their dimensions measured a nominal 1.13 inches $(2.87 \mathrm{~cm})$ in diameter by 0.5 inches $(1.27 \mathrm{~cm})$ in height. Duplicate specimens for each waste-binder combination were placed in the chamber and cycled between $+60^{\circ} \mathrm{C}$ and $-40^{\circ} \mathrm{C}$ for a total of 30 cycles in accordance with NRC recommendations. Temperatures were held at each extreme for a period of one hour, separated by one hour at $20^{\circ} \mathrm{C}$. Temperature ramp times varied between 8 minutes $\left(200 \mathrm{C}\right.$ to $600^{\circ} \mathrm{C}$ ) and 15 minutes $\left(20^{\circ} \mathrm{C}\right.$ to $\left.-400 \mathrm{C}\right)$. The total time required to complete one cycle was approximatley 5 hours as seen in Figure 5.5 which presents a graphical representation of cycling conditions. Chamber temperatures were recorded by a 24 hour circular chart recorder. In addition, representative specimens were monitored by thermocouples to verify uniform temperatures throughout the chamber and to track their response to changes in chamber temperatures.

Upon completion of themal cycling, specimens were removed from the chamber for further testing. No visible changes in structure or physical dimensions were observed. Specimens were then subjected to plastic deformation testing as described in Section 5.3. Results of these tests are given in terms of percent deformation and percent recovery in Table 5.3. Data are compared with results from non-thermal cycled specimens in Figure 5.3 where they are depicted by the shaded bars in the historgram. 
Table 5.3

Results of Waste Fom Deformation Testing Under $100, p s i$
Compressive Load for Thermal Cycled Specimens $(a),(b)$

\begin{tabular}{|c|c|c|c|c|c|c|}
\hline $\begin{array}{c}\text { Test } \\
\text { Specimen } \\
\text { No. } \\
\end{array}$ & $\begin{array}{l}\text { Waste } \\
\text { Type } \\
\end{array}$ & $\begin{array}{c}\text { Waste } \\
\text { Loading, wt\% } \\
\end{array}$ & $\begin{array}{l}\text { LDPE } \\
\text { Type } \\
\end{array}$ & $\begin{array}{l}\text { Original } \\
\text { Thickness, } \\
\text { cm. } \\
\end{array}$ & $\begin{array}{c}\text { Deformation, } \\
\%\end{array}$ & $\begin{array}{c}\text { Recovery, } \\
\% \\
\end{array}$ \\
\hline $4-5$ & $\mathrm{Na}_{2} \mathrm{SO}_{4}$ & 54 & 1409 & 1.27 & 0.17 & 100 \\
\hline $9-10$ & $\mathrm{Na}_{2} \mathrm{SO}_{4}$ & 60 & 1409 & 1.27 & 0.25 & 100 \\
\hline $14-15$ & $\mathrm{Na}_{2} \mathrm{SO}_{4}$ & 70 & 1409 & 1.27 & 0.18 & 99.8 \\
\hline $19-20$ & $\mathrm{H}_{3} \mathrm{BO}_{3}$ & 30 & 1410 & 1.27 & 0.13 & 99.9 \\
\hline $24-25$ & $\mathrm{H}_{3} \mathrm{BO}_{3}$ & 40 & 1410 & 1.26 & 0.16 & 100 \\
\hline $29-30$ & I.X. Resin & 28 & 1410 & 1.27 & 0.24 & 100 \\
\hline $34-35$ & I.X. Resin & 50 & 1410 & 1.26 & 0.33 & 100 \\
\hline $39-40$ & I.X. Resin & 60 & 1410 & 1.27 & 0.29 & 100 \\
\hline $44-45$ & I.X. Resin & 65 & 1410 & 1.27 & 0.16 & 100 \\
\hline $49-50$ & I.X. Resin & 60 & 1409 & 1.28 & 0.10 & 100 \\
\hline $54-55$ & I.X. Resin & 50 & 1117-B & 1.26 & 0.39 & 100 \\
\hline $59-60$ & Ash & 20 & 1409 & 1.28 & 0.41 & 100 \\
\hline $64-65$ & Ash & 40 & 1409 & 1.28 & 0.07 & 99.5 \\
\hline $69-70$ & Ash & 40 & $C-17$ & 1.27 & 0.20 & 99.8 \\
\hline
\end{tabular}

a) Performed in accordance with ASTM D-621

b) Results reflect average values for 2 replicate specimens 


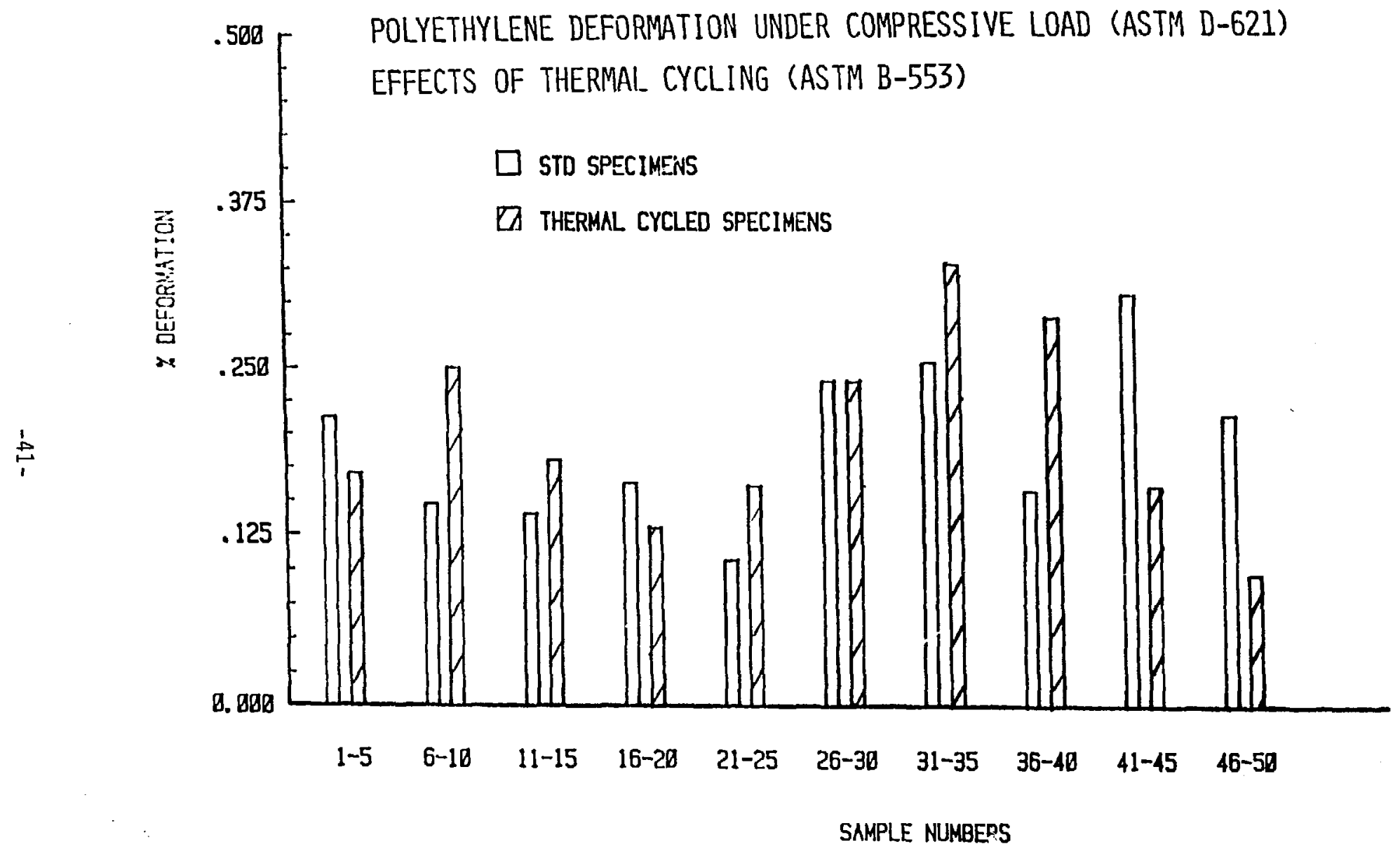

Figure 5.3 Histogram depicting results of waste form deformation under compressive load for thermal cycled and non-thermal cycled specimens. Sample numbers correspond to data in Tables 5.2 and 5.3 . 


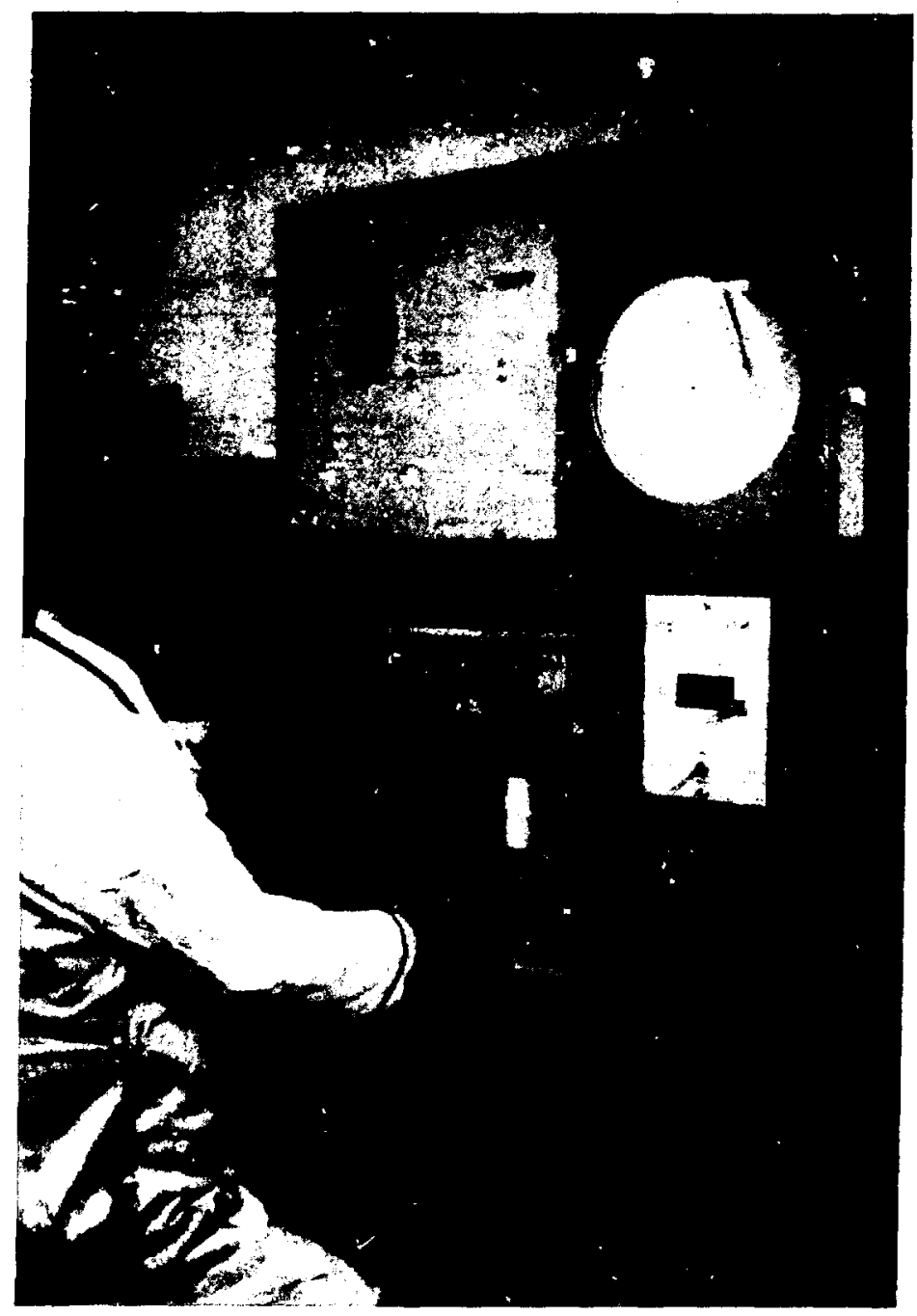

Figure 5.4 Photograph of microprocessor controlled thernal cycle environmental chamber for conditioning specimens according to ASTM B-553. 


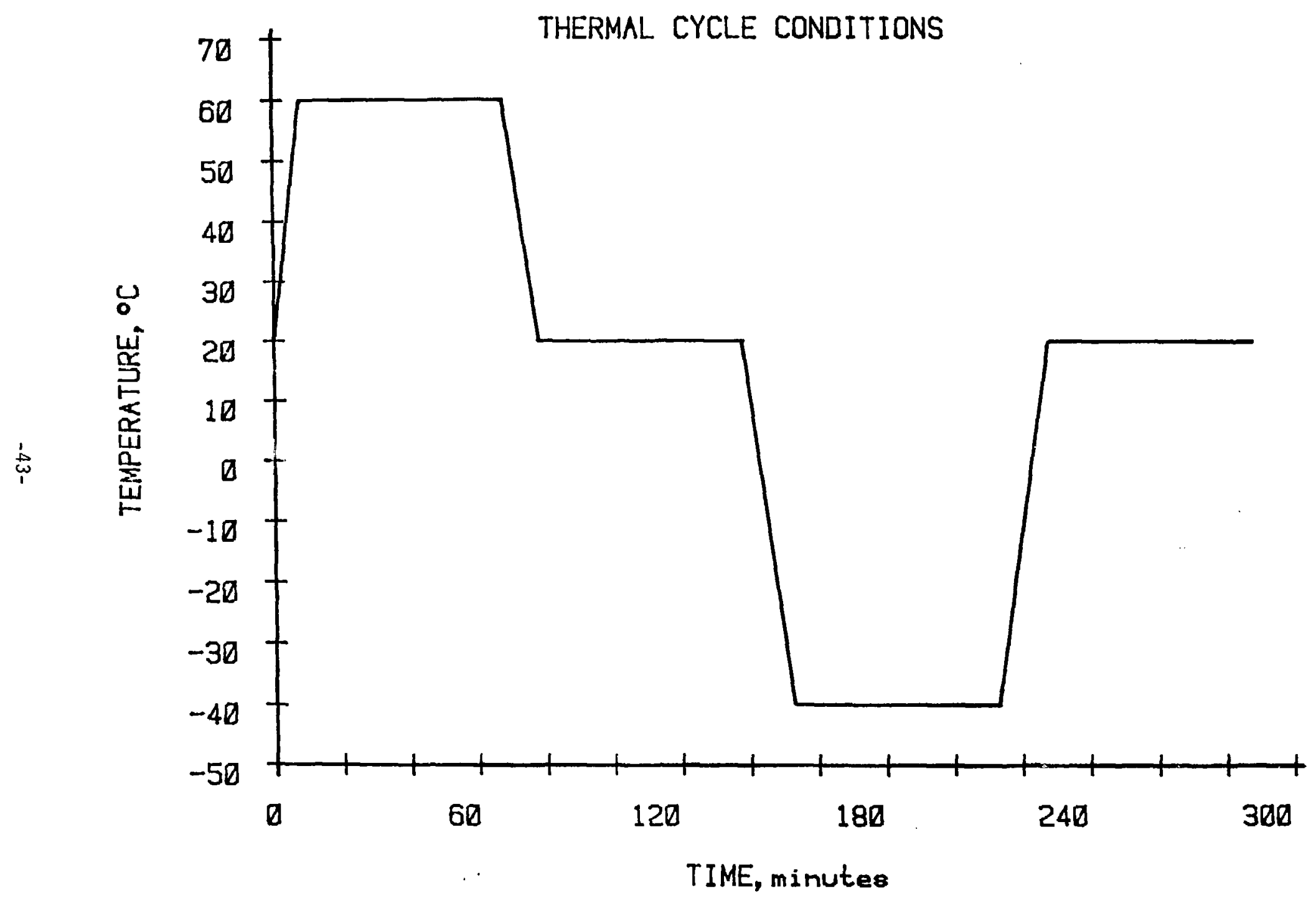

Figure 5.5 Graphical representation of temperature conditions and duration for one thermal cycle. 
Deformation results of themal cycled specimens again showed little distortion under a compressive load of $100 \mathrm{psi}$. Total deformation did not exceed $0.41 \%$ and variability between samples was small ( $0.34 \%$ deformation separated minimum and maximum values). Thermal cycling did not impair the ability of the waste forms to return to their original dimensions. Percent recovery ranged between 99.5 and $100 \%$ for all samples. Comparison of the data presented in Tables 5.2 and 5.3 and in Figure 5.3 reveals that no clear trend exists for the effects of thermal cycling on polyethylene. In some cases deformation decreased, others it increased, and still others it remained constant as compared with replicate samples which were not thermal cycled. Since no trend is evident and the magnitude of differences is small, these variations are probably attributable to experimental error.

\subsection{Leaching Tests}

5.5.1 Leaching Test Method: Leach testing was performed in accordance with the ANS 16.1 Standard, "Measurement of the Leachability of Solidified Low-Level Radioactive Wastes"30. This test was designed to provide a standardized laboratory method for characterizing the leaching behavior of low-level waste forms. Use of a standardized method enables the evaluation of independent data on a common basis. It's procedures do not necessarily simulate waste form leaching under actual burial conditions but rather allow a comparison of the relative leachability of various waste-binder combinations. The NRC has therefore, recommended its use for demonstration of waste form stability criteria set forth in 10 CFR 61.

5.5.2 Sample Preparation: Simulated radioactive waste forms were prepared containing 10,30 and 50 wt\% sodium sulfate, and 25 and 35 wt $\%$ incinerator ash. $137 \mathrm{Cs}$ and $60 \mathrm{Co}$ tracers were added at a nominally constant ratio of $0.25 \mu \mathrm{Ci}$ per gram of waste while $85 \mathrm{Sr}$ was incorporated at a ratio of approximately $0.06 \mu \mathrm{Ci}$ per gram of waste. Activity concentrations found in actual low-level waste may vary over several orders of magnitude. Therefore, activity concentrations for this experiment were selected which were both reasonable from the standpoint of simulating actual waste and practicai from the standpoint of experimental considerations, e.g., detection 1 imits and radiation dose levels.

In order to evenly distribute the aqueous tracer activity throughout the dry powdered simulated sodium sulfate waste, the following procedure was employed. A quantity of sodium sulfate was weighed and then dissolved in distilled water at elevated temperature to increase solubility. The appropriate volumes of liquid tracer were pippeted and thoroughly mixed. The solution was evaporated to dryness and the remaining salt cake removed. The tracer activated sodium sulfate was then crushed to a fine powder by mortar and pestle.

Incinerator ash was prepared in a similar fashion. Tracers were pippeted into a slurry $c f$ ash and distilled water which was then thouroughly mixed. Upon evaporation the ash was al so crushed to a fine powder.

In order to avoid contamination of the screw extruder employed to make non-radioactive waste forms, polyethyl ene leaching specimens were formulated from the tracer activated simulated wastes by use of a dual action heated mixing vessel as seen in Figure 5.6. This stainless steel mixer is heated by a 


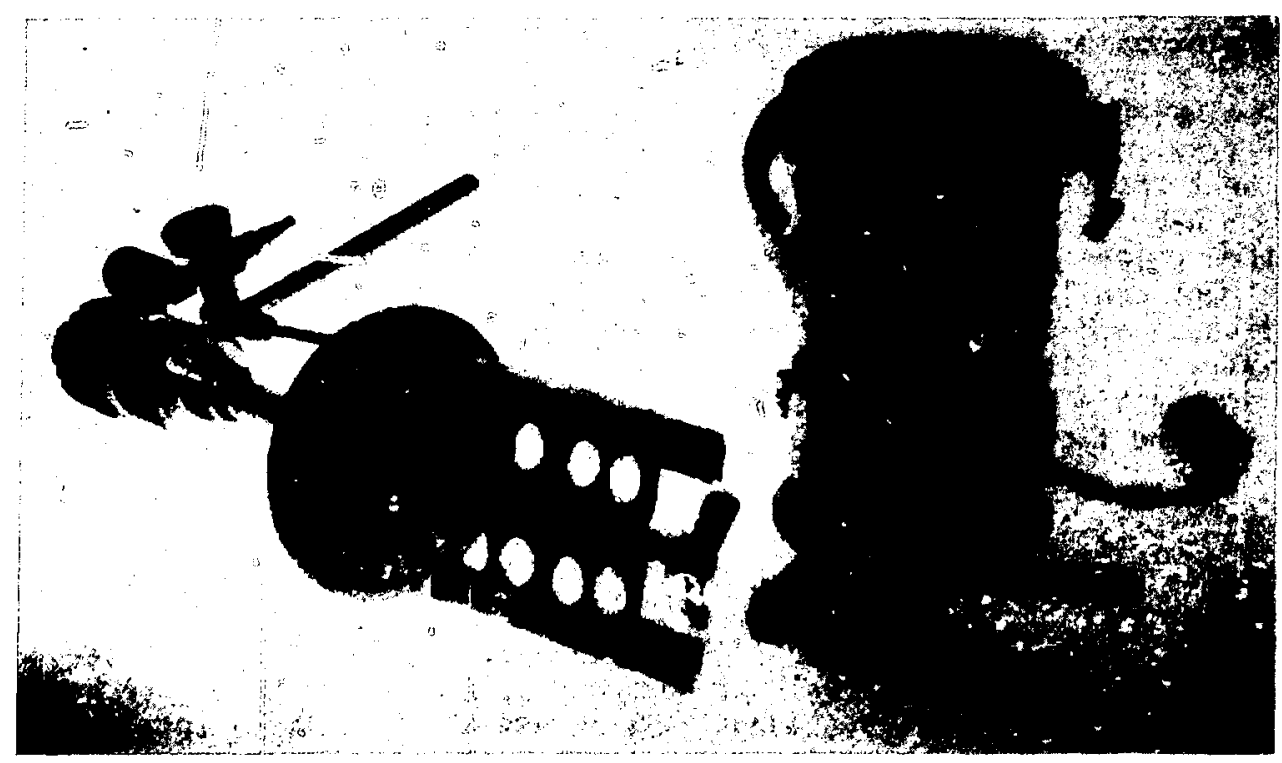

Figure 5.6 Duat action heated mixing vessel employed for the production of polyethylene leaching specimens. 
series of external electrical resistance band heaters controlled by a digital time-proportioning temperature controlier. Stirring of the waste-binder mixture is accomplished by the conbined action of an impeller blade and teflon wiper, powered by an air driven motor. Use of this mixer required that formulations contain less waste than those processed by extrusion, and processing times be extended to compensate for less efficient mixing.

Pre-weighed quantities of waste and binder were placed in the mixer. The temperature controller was set at $182^{\circ} \mathrm{C}$ (360\%) and the mixture was allowed to heat until melting. Stirring was then initiated and continued at speeds of 10-15 RPM for approximately two hours to assure homogeneity. Specimens were then placed in $4.8 \mathrm{~cm}$ ( 1.9 inch) diameter copper molds and allowed to cool. Upon cooling, waste forms were trimmed to a uniform height of $9.0 \mathrm{~cm}$ ( 3.5 inches) and the surface of the cut ends were re-sealed by heating over a hot plate. Final dimensions were recorded and the specimens were weighed. Waste. $m$ activity source terms were calculated based upon the waste loading (wt\%) and the final weight of each specimen.

5.5.3 Experimental Procedure: Specimens were leached in demineralized water. The volume of leachant employed was $1700 \mathrm{ml}$ as specified by the ratio of leachant volume to external geometric surface area of $10 \pm 0.2 \mathrm{~cm}$. Temperature was maintained at $20 \pm 2^{\circ} \mathrm{C}$. Leachant was replenished at the recommended incremental intervals of 30 seconds, 2 hours, 5 hours, 17 hours, once each day for the next four days, 13, 28 and 45 days, for a total leaching time of 91 days.

Leachate aliquots of approximately $50 \mathrm{ml}$ were collected for analysis and acidified with $1 \mathrm{ml}$ of nitric acid. $10 \mathrm{ml}$ sub-samples were then prepared for gamma counting. A Searle Model $1185 \mathrm{NaI}$ detector with three single channel analyzers and an automatic sample changer was employed for leachate analysis. Counting data were analyzed by a program written for a Hewlett Packard micro computer which perfomed background and channel spillover compensation and calculated incremental and cumulative fraction release.

5.5.4 Leaching Results: Cumulative fraction release of $85 \mathrm{Sr}, 137 \mathrm{Cs}$, and $60 \mathrm{Co}$ are plotted as a function of leaching time (in days) for the 10, 30 , and 50 wt\% sodium sulfate waste forms in Figures 5.7-5.9. A comparison of 60 Co leachability for each waste loading is presented in Figure 5.10 . ACtivity release data from the 25 and $35 \mathrm{wt} \%$ incinerator ash specimens are plotted in Figure 5.11 and 5.12 .

In general, all three isotopes leach at similar rates from sodium sulfate waste forms indicating a lack of cheinical interaction between the waste and polyethylene binder. Maximum fraction releases after 91 days ranged between $3.3 \times 10^{-3}(137 \mathrm{Cs})$ and $6.2 \times 10^{-3}(85 \mathrm{Sr}$ and $60 \mathrm{Co})$ for the waste form containing 10 wt\% sodium sulfate. For the 30 wt\% sodium sulfate specimens, releases ranged between $7.4 \times 10^{-3}$ (137 Cs) and $7.9 \times 10^{-3}(60 \mathrm{Co})$. Final fraction releases for the 50 wt\% sodium sulfate waste forms were $1.9 \times$ $10^{-2}(85 \mathrm{Sr}), 2.3 \times 10^{-2}(60 \mathrm{Co})$ and $3.1 \times 10^{-2}(137 \mathrm{Cs})$. 


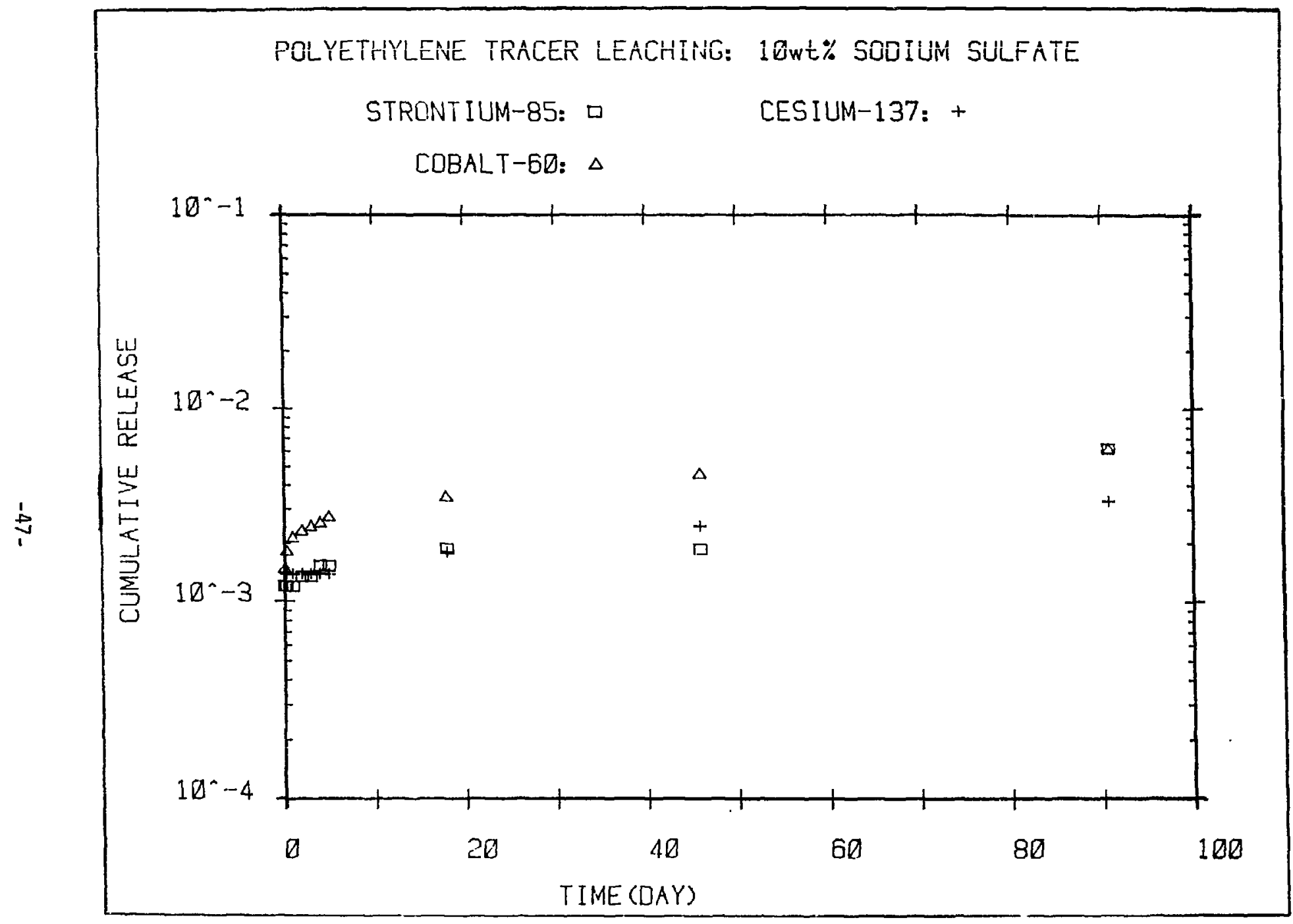

Figure 5.7 Cumulative fractional activity release for polyethylene waste form containing 10 wt\% sodium sulfate. 


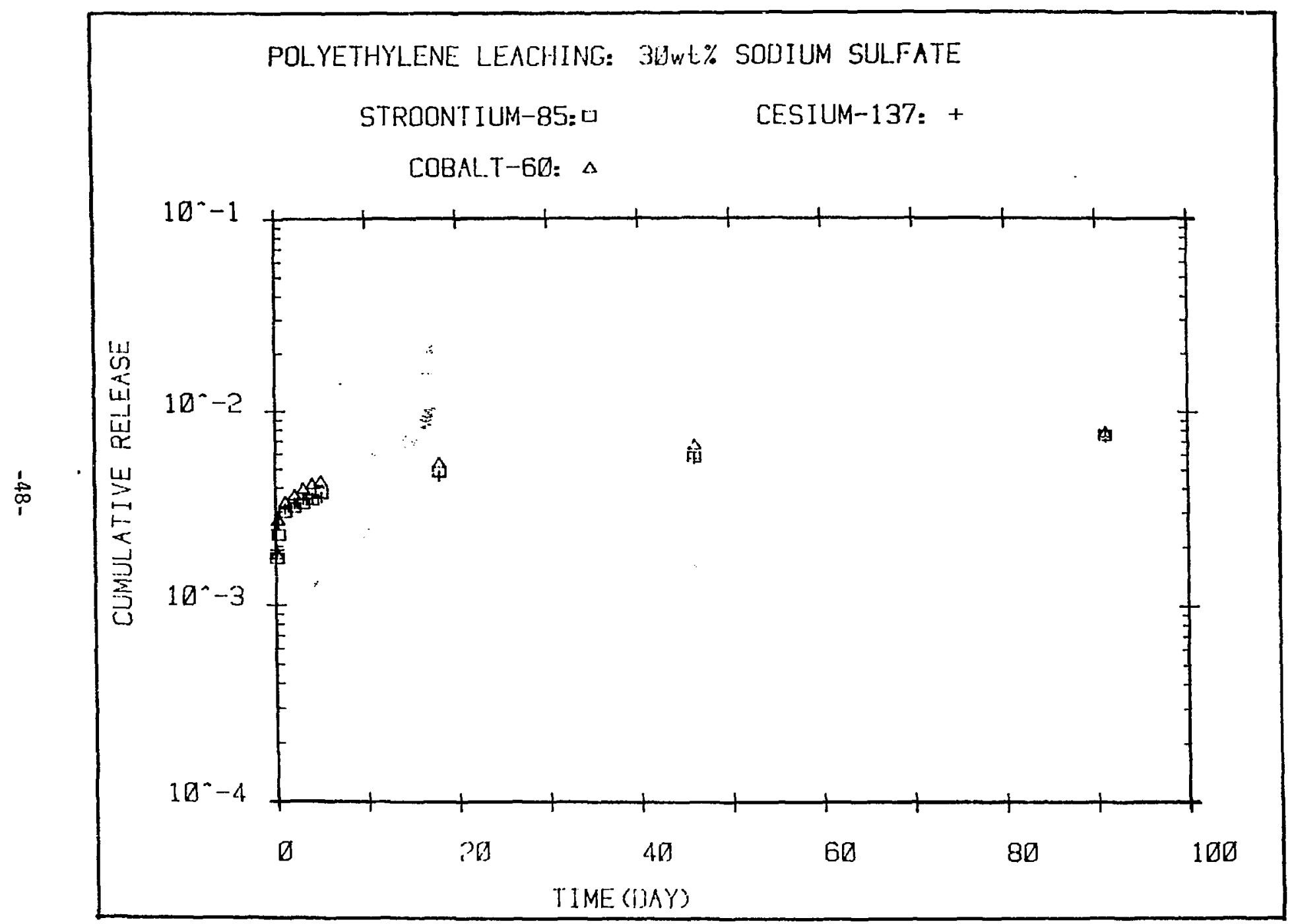

Figure 5.8 Cumulative fractional activity release for polyethylene waste form containing $30 \mathrm{wt} \%$ sodium sulfate. 


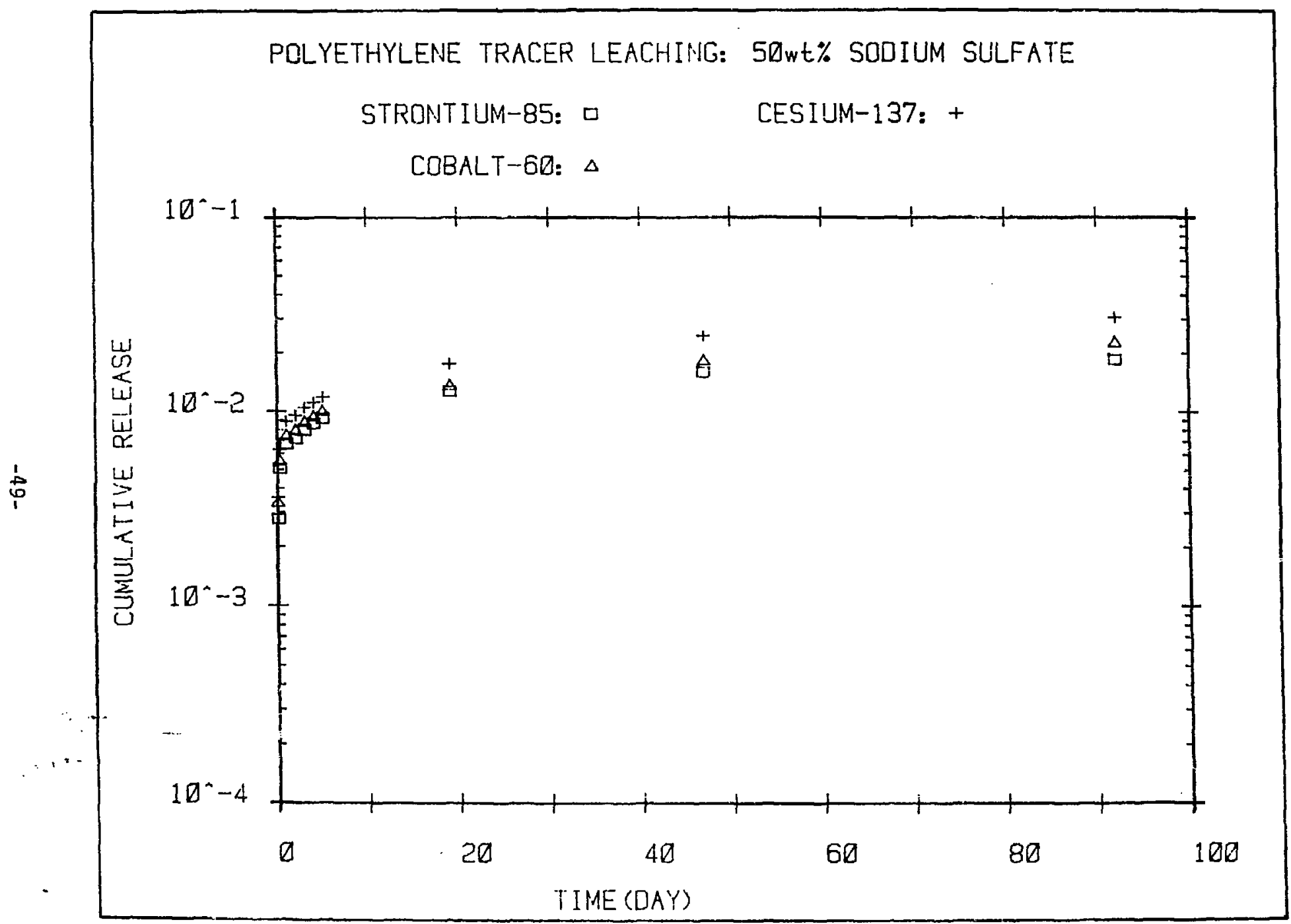

Figure 5.9 Cumulative fractional activity release for polyethylene waste form containing $50 \mathrm{wt} \%$ sodium sulfate. 


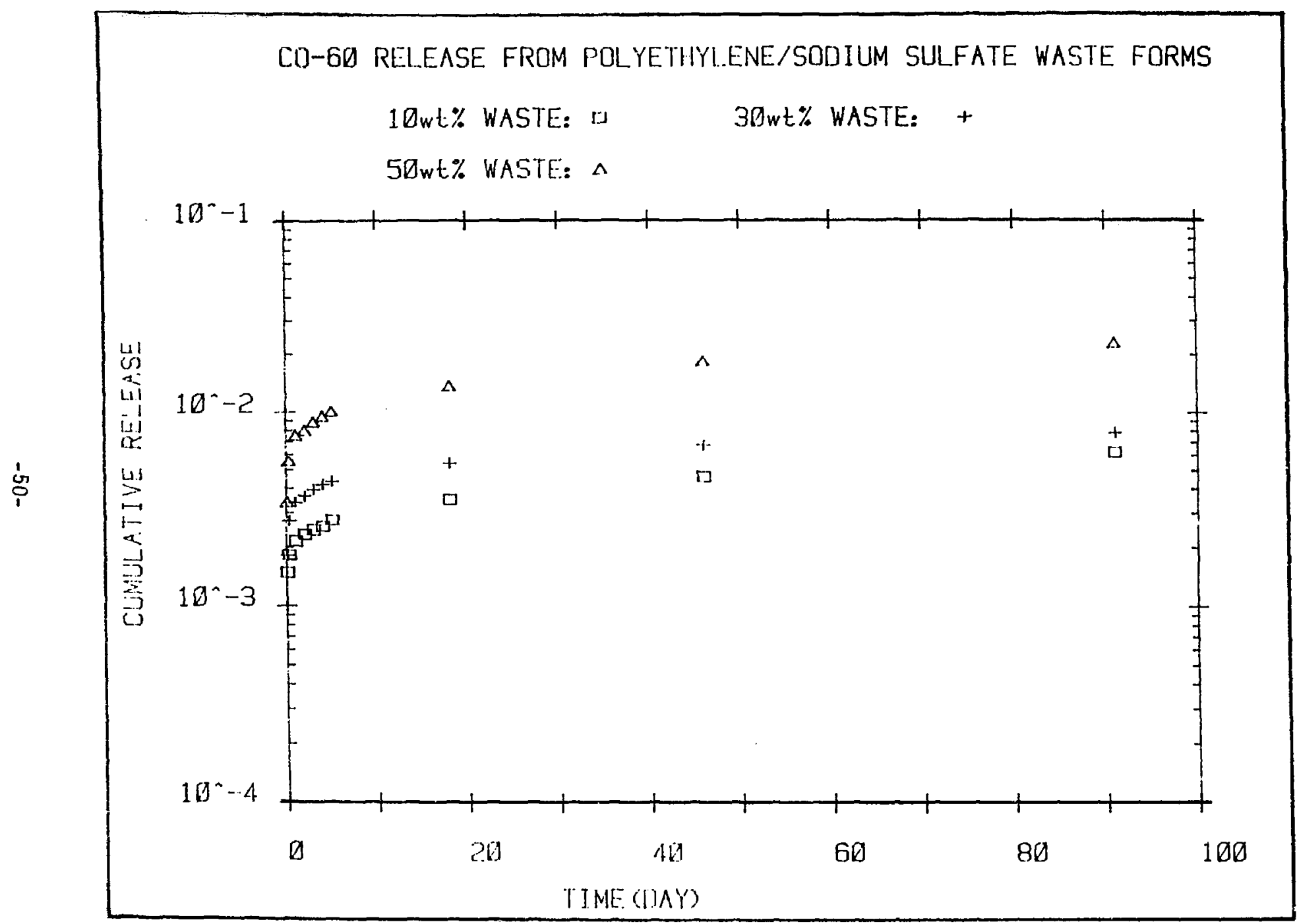

Figure 5.10 Comparison of the 60 Co cumulative fractional activity release for polyethylene waste forms containing 10,30 , and 50 wt\% sodium sulfate. 


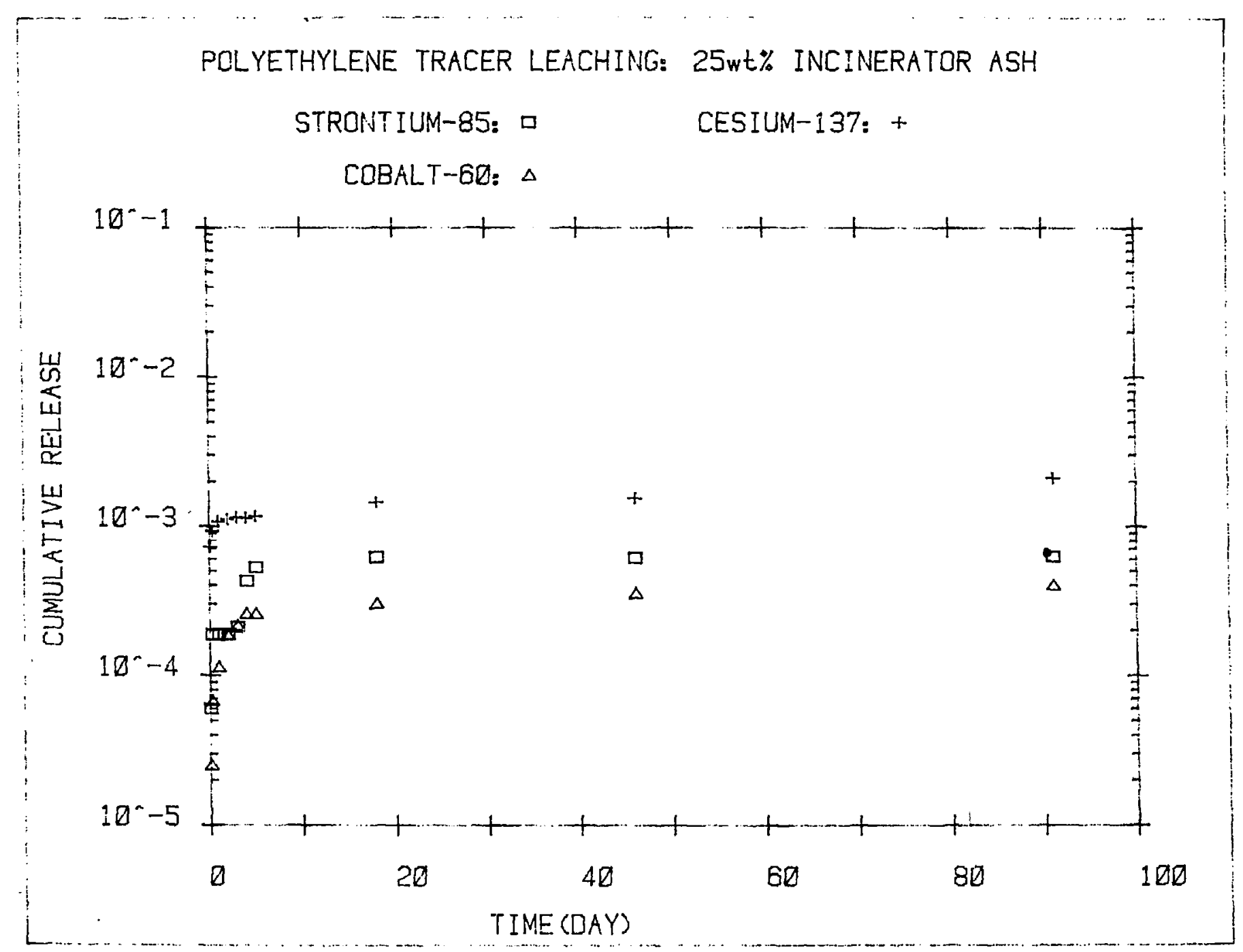

Figure 5.11 Cumulative fractional activity release for polyethylene waste form containing 25 wt\% incinerator ash. 


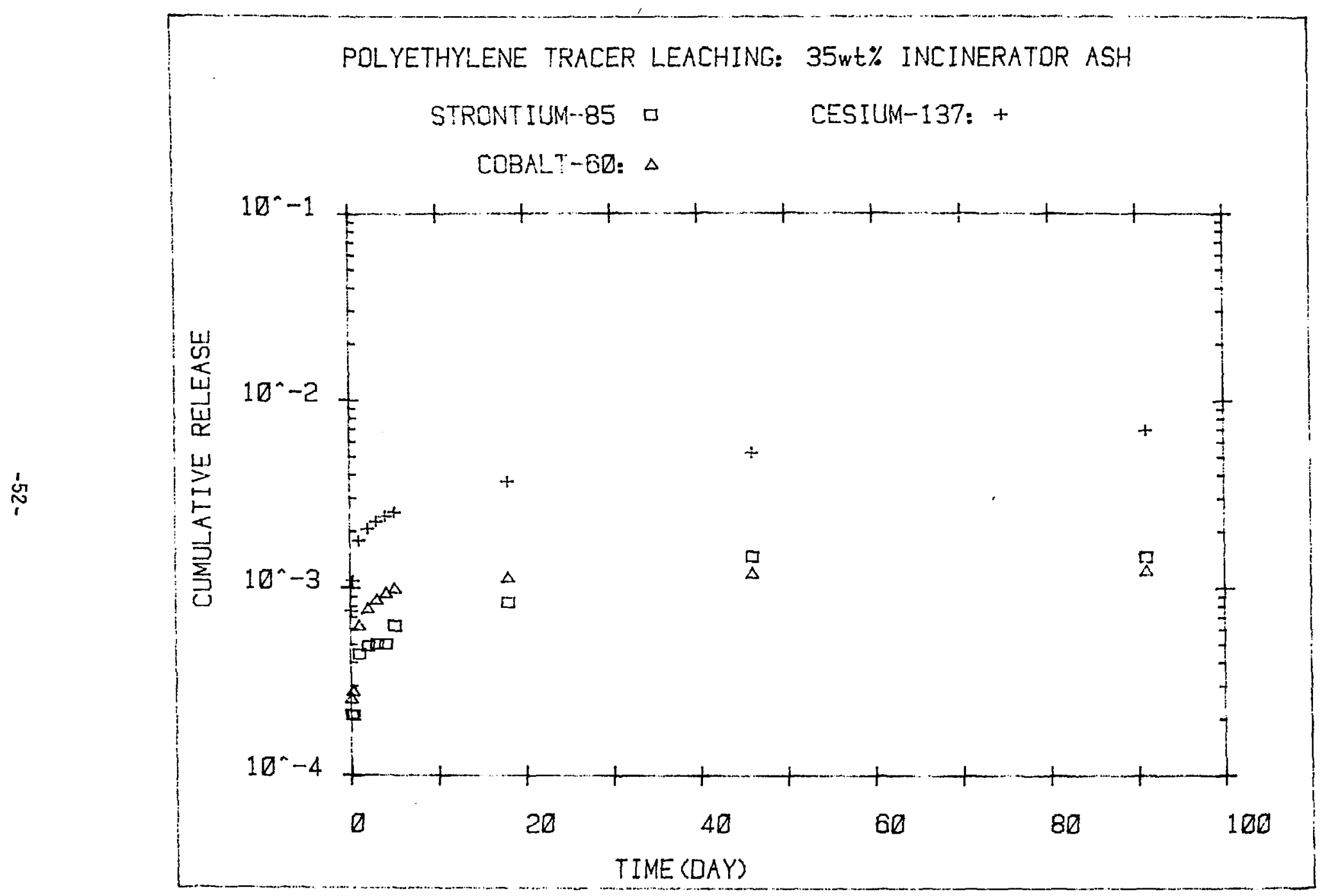

Figure 5.12 Cumulative fractional activity release for polyethylene waste form containing 35 wt\% incinerator ash. 
The comparison of 60 Co release as a function of waste loading as shown in Figure 5.10 demonstrates a correlation between leachability and the quantity of sodium sulfate incorporated. Since this waste is a highly soluble salt, mobilization of contained radionuclides is controlled in part by leachate dissolution of the waste. Immobilization of activity in polyethylene is dependent upon the physical encapsulation of waste. Higher loadings decrease the amount of binder available to encapsulate the weste material. In addition, as more sodium sulfate comes into contact with ieachate and dissolves, porosity increases (as a result of the voids left behind) creating more pathways for migration.

Leachability from the incinerator ash waste forms was lower than from those containing sodium sulfate. Final cumulative fraction releases from the 25 wt\% ash sample were $4.1 \times 10^{-4}(60 \mathrm{Co}), 6.3 \times 10^{-4}(85 \mathrm{Sr})$ and $2.1 \times$ $10^{-3}$ ( $\left.137 \mathrm{Cs}\right)$. An increase in waste loading to $35 \mathrm{wt} \%$ ash again resulted in higher fraction releases: $1.3 \times 10^{-3}\left(60^{\circ} \mathrm{Co}\right), 1.5 \times 10^{-3}(85 \mathrm{Sr})$, and $6.7 \times 10^{-3}(137 \mathrm{Cs})$. For the less soluble ash this increase in activity may be attrit +ed to the reduced amount of binder available for waste encapsulation. i.l contrast to the relatively uniform leaching of all three isotopes evident in the sodium sulfate specimens, ${ }^{137} \mathrm{Cs}$ is somewhat more mobile than ${ }^{85} \mathrm{Sr}$ and $60 \mathrm{Co}$ for solidified ash waste forms. Since polyethylene does not chemically interact with the waste, this disparity in leachability between isotopes suggests that the incinerator ash itself, exhibits preferential sorption. 


\section{THE ECONOMICS OF VOLUME REDUCTION/POLYETHYLENE SOLIDIFICATION}

\subsection{Introduction}

The lack of adequate economical disposal of low-level waste has led to increased interest in the use of volume reduction technology. While the technical benefits of volume reduction (VR) are widely recognized, its economic impact is less clear and is dependent upon a number of factors including the cost and availability of disposal, transportation costs, and system costs associated with VR technology.

A study was conducted to determine the economic feasibility of a VR system for aqueous reactor wastes in conjunction with solidification of the resulting dry solid residues in low density polyethylene. These results are compared with the "null" alternative of no volume reduction and solidification of the aqueous LLW in hydraulic cement. The latter alternative is currently practiced by the majority of commercial utilities operating light water power reactors in the United States. Although this analysis employed data from the commercial sector (as this information is readily available) many similarities are anticipated for the treatment of similar DOE low-level wastes.

The volume reduction system selected for this study consists of a fluidized bed calciner/incinerator with solidification of resultant residues in low density polyethylene (in 55 gallon drums) by extrusion. The fluidized bed system is capable of reducing both BWR and PWR concentrated liquids to complete dryness (resulting in VR factors of 5.8 and 11.6 , respectively) and incineration of ion exchange resin wastes (resulting in a VR factor of 15.0) 31. Although the scope of this study was limited to the consideration of aqueous wastes, combustible dry active wastes may also be treated by this technique.

\subsection{Technical and Economic Assumptions}

As in any economic analysis, this investigation was based on a number of technical and economic assumptions. Some of these factors are outlined below but a more complete discussion is included in Reference 32.

Typical waste generation rates from an 800 MWe BWR and PWR operated at $80 \%$ capacity were assumed. This equates to $5800 \mathrm{ft}^{3} / \mathrm{yr}$ of sodium sulfate evaporator bottoms and $2100 \mathrm{ft}^{3} / \mathrm{yr}$ of ion exchange resins for an average BWR. For PWRs the average generation rates are $2800 \mathrm{ft}^{3} / \mathrm{yr}$ of boric acid evaporator concentrates and $400 \mathrm{ft} 3 / \mathrm{yr}$ of ion exchange resins.

Cement solidification efficiency assumed $30 \mathrm{gallons}$ of concentrated waste/drum and $2.5 \mathrm{ft}^{3}$ of ion exchange resins/drum. These efficiences yield a yearly total of 145155 gallon drums of concentrate waste and 842 drums of resin waste for a typical BWR. Likewise, 696 drums of concentrate waste and 163 drums of resin waste are produced yearly by an average PWR. 
Solidification efficiencies in polyethylene were chosen conservatively, based on results from process development studies (maximum loadings were not employed). $60 \mathrm{wt} \%$ sodium sulfate, $25 \mathrm{wt} \%$ boric acid and 25 wt\% incinerated resin ash were assumed. Based on the same waste generation rates given above, this equates to 278 drums of concentrate waste and 20 drums of resin waste per year for a BWR. Similarly, volume reduction and polyethylene solidification result in 145 drums of concentrate waste and 5 drums of resin waste yearly for a PWR.

A total capital investment of 12.5 million dollars was allowed for purchase and installation of the volume reduction system. For simplicity it was assumed that cement and polyethylene solidification capital costs were equal, and thus were not included. The analysis is based on installation of a new facility, not a retrofit of an existing plant.

Labor, materials, operating and maintenance costs were assumed to escalate at $10 \% /$ year, while transportation costs were expected to rise at 15\%/year. Disposal costs have risen dramatically at an average of $40 \% /$ year over the last 10 years. Results presented here assume that this trend will continue. The sensitivity of burial cost escalation on the total economic evaluation is discussed in Reference 32.

\subsection{Economic Analysis}

Economic evaluation was performed using a levelized revenue requirement technique, as outlined by the Electric Power Research Institute (EPRI), in their Technical Assessment Guide 33. The financial mathematics utilized in this method are based on the fundamental engineering economic principles of the "time value of money." Levelized revenue requirement is defined as the total amount of money that must be collected by a utility for all expenditures associated with the implementation of an alternative decision, converted to a series of equivalent annuities over time.

A shori term revenue requirement analysis was selected as being the most appropriate. This method examines the levelized revenue requirement of a long life project over the first several years. As recommended by EPRI, the analysis was conducted for a period of 10 years.

\subsection{Results}

Level ized revenue requirement analyses were conducted for three transportation distances, with the results summarized in Figure 6.1. The data indicate that a net annual savings can be realized in the implementation of the volume reduction/polyethylene sol idification option for each case considered. In general, a greater cost differential in waste treatment/solidification options is seen for BWRs than for PWRs. In light of the fact that BWRs generate 5 times more ion exchange resin waste and twice as much concentrated liquid waste, this is not surprising. 


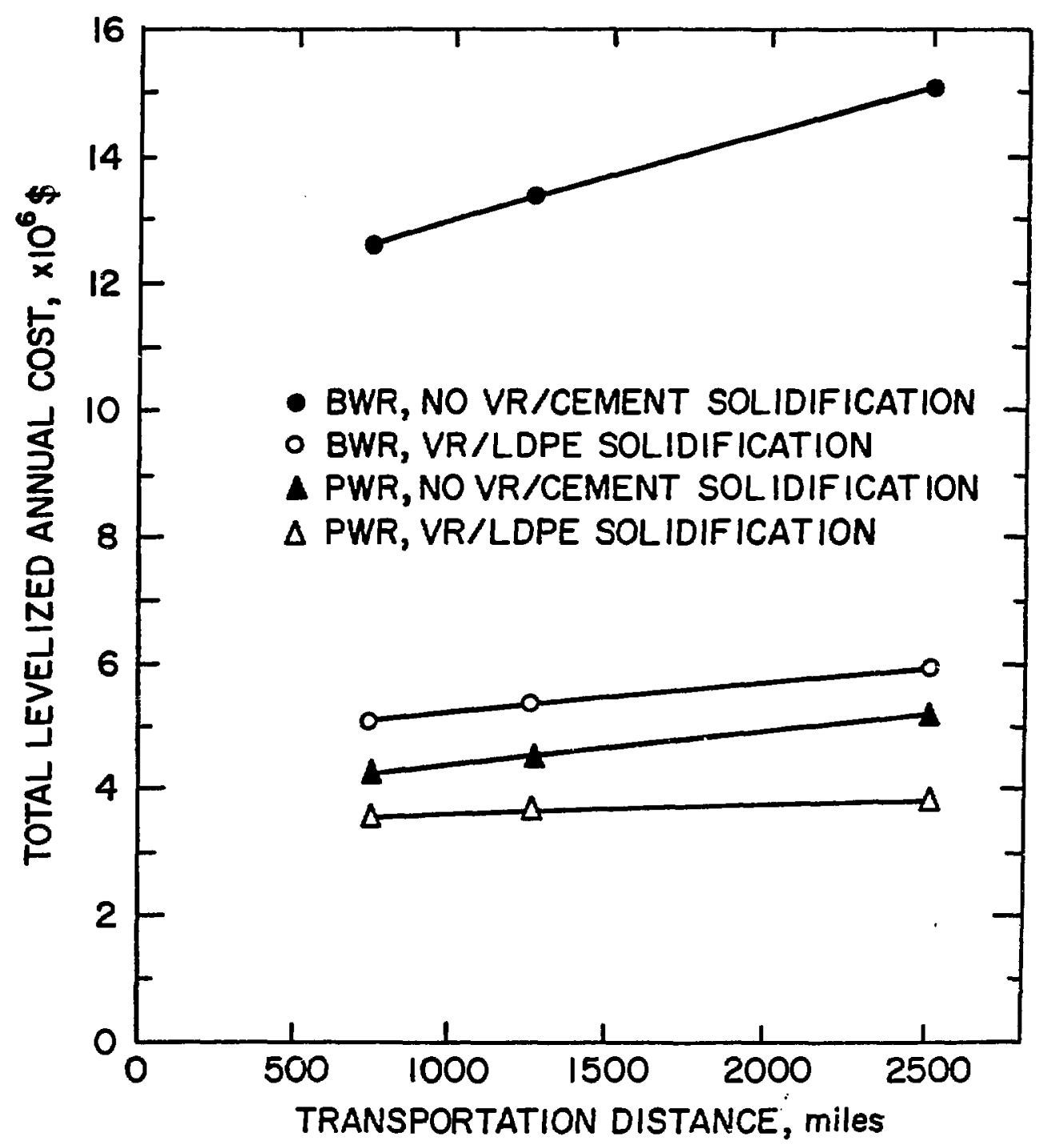

Figure 6.1 Total levelized annual cost (in millions of dollars) as a function of transportation distance to the burial site for each of the options considered. 
The largest cost savings of just over $\$ 9$ million per year, is forecast for a BWR which must ship its solidified waste 2,500 miles for disposal. The smallest net annual savings of approximately $\$ 0.7$ million per year was calculated for a PWR whose transportation distance is only 750 miles. The volume reduction option tends to flatten the effects of increased transportation distances, as illustrated by Figure 6.1. For both PWRs and BWRs the effects of increased shipping distance for volume reduced wastes is negligible when compared with those for the "null" alternative.

One factor included in the current burial cost pricing structure is a surcharge based on activity. However, in spite of this apparent disincentive for volume reduction, the cost benefits derived by reducing waste volume and solidifying in low density polyethylene far exceed the penalties incurred due to higher radioactivity concentrations. The inclusion of other reactor wastes such as filter sludge, filters and trash are estimated to provide further cost savings by volume reduction.

The cost projections included in this study are based upon technical and economic assumptions, as required. Technical specifications, al though based on real data as supplied by vendors and in the literature, represent hypothetical systems and thus are subject to variation. In the realm of economic forecasting, the greatest uncertainty lies in the estimation of shallow land burial disposal costs. Although the large annual disposal cost escalation used in this study (40\%/year) is historically documented, the political, social, and economic situation in the next 10 years may greatly alter (increase or decrease) this factor. 


\section{SUMMARY AND CONCLUSIONS}

Maximum waste loadings for each waste type based upon processing constraints are reported in Section 4. Waste form performance test results are presented in Section 5. Recommended formulational limits which allow optimal waste loadings while at the same time do not adversely affect the properties of sol idified waste forms are discussed in this section. Finally, recommended waste loadings for the polyethylene matrix are compared with waste loadings for typical hydraulic, cement waste forms.

In general, increased waste loading for polyethylene/sodium sulfate specimens had little effect on the properties of solidified waste forms. For specimens containing maximum waste loadings of $70 \mathrm{wt} \%$ salts, water immersion testing caused only minor swelling $(\leq 1.7 \%)$, deformation under 100 psi conpressive load was slight $(\leq 0.14 \%)$, and thermal cycling did not significantly alter deformation resistance. The leaching of 10,30 , and 50 wt\% sodium sulfate waste forms demonstrated a clear leachability dependence upon waste loading. However, leach rates of $85 \mathrm{Sr}, 137 \mathrm{Cs}$, and $60^{\circ} \mathrm{Co}$ were sufficiently low ( $<3.1 \times 10^{-2}$ cumulative fraction released after 91 days) that leachabi? ity should not impose a restraint on maximum sodium sulfate waste loading. Wasce loadings of 70 wt\% sodium sulfate were achieved using polyethylenes with melt index values of 35.0 and $55.0 \mathrm{~g} / 10$ minutes. Since no solidification efficiency is gained by employing the higher melt index plastic for this waste type, use of the lower melt index material is recommended to provide increased durability and mechanical strength. A loading efficiency of $70 \mathrm{wt} \%$ sodium sulfate equates to over 550 lbs of dry waste solidified per 55 gallon drum size waste form.

Typically, aqueous sodium sulfate evaporator concentrates containing approximately 25 wt\% salts are solidified in hydraulic cement. Waste loadings in the range of 25 to 30 gallons of BWR evaporator concentrates per 55 galion drum are reported 31,34 . These loadings correspond to equivalent dry waste loadings of 10 to $12 \mathrm{wt} \%$, (approximately 82 lbs dry sodium sulfate per 55 gallon drum size waste form) depending upon the waste to cement ratio employed. Laboratory experiments suggest that portland cement waste forms containing $>9$ wt\% sodium sulfate (approximately 61 lbs dry waste per 55 gallon druf sjze waste form) may suffer severe deterioration in water immersion testing 35 , further reducing the quantities of this waste stream which may be solidified in cement under the new NRC guidelines on was 'a form performance.

Results of property evaluation testing for polyethylene/boric acid samples indicate that waste loading does not adversely affect the performance of sol idified waste forms. Specimens containing between 35 and $50 \mathrm{wt} \%$ boric acid showed little or no swelling in water immersion $(\leq 0.2 \%)$. Deformation under 100 psi compressive load decreased with additionaT waste loading and for specimens containing $40 \mathrm{wt} \%$ boric acid deformation was $0.11 \%$. Themal cycling had little impact on mechanical strength. Although no leach tests were performed for boric acid waste forms, the predominant leaching mechanisms for this waste-solidification agent combination are expected to be similar to those of sodium sulfate in polyethylene. In that boric acid solubility is lower than that of sodium sulfate, leachability may in fact be lower. It is concluded, 
therefore, that leachability will not constrain maximum boric acid waste loadings in polyethylene. A maximum waste loading of $50 \mathrm{wt} \%$ boric acid (equivalent to approximately 248 lbs dry waste/55 gallon drum size waste form) is recommended.

Solidification of boric acid waste streams in hydraulic cement is limited by the inhibiting effects of the waste on cement hydration. Masonry cement which contains $50 \mathrm{wt} \%$ slaked 1 ime is commonly used since the lime partially counteracts the inhibiting effects of the waste. Actual waste forms contain between 4 and 5 wt\% boric acid when calculated on a dry weight bas is 31,36 for a total of approximately 33 lbs dry waste per 55 gallon drum size waste form. Laboratory data suggest that a maximum of 15 wt\% boric acid (approximately 98 lbs dry waste $/ 55$ gal drum size waste form) may be successfully solidified in masonry cement to form monolithic solid waste forms 35 .

The behavior of polyethylene waste forms containing incinerator ash was similar to those incorporating dry salt wastes. A smali degree of swelling was recorded for ash specimens undergoing water immersion testing $(\leq 2.0 \%)$. Specimens held under 100 psi compressive load deformed to a lesser extent with additional waste incorporation $10.18 \%$ for 20 wt\% waste, $0.08 \%$ for 40 wt\% waste) and thermal cycling had little effect on deformation results. Leaching results for specimens containing 35 wt\% ash indicated a maximum cumulative fraction release of $\leq 6.7 \times 10^{-3}$ so that leachability considerations would not limit incinerator ash loading efficiencies. Waste forms with a maximum waste loading of $40 \mathrm{wt} \%$ ash were produced with both an injection molding grade LDPE and a lower molecular weight non-emulsifiable wax. From the standpoint of resistance to deformation and general durability, the injection molding grade polymer is a preferable binder material.

Although incinerator ash is not solidified routinely, laboratory studies have shown that $40 \mathrm{wt} \%$ may be successfully incorporated in portland type I cement 16 . This equates to approximately 280 ibs ash for a typical seven cubic foot 55 gallon drum size waste form. Due to a lower waste form product density, $40 \mathrm{wt} \%$ ash loading in polyethylene yields approximately $238 \mathrm{lbs}$ ash/drum (18\% less than cement).

Ion exchange resin waste forms were solidified which contained as much as $65 \mathrm{wt} \%$ dry resin waste. However, when subjected to a 90 day water immersion test, specimens contailling $50 \mathrm{wt} \%$ resin swelled significantly (approximately $9 \%$ ), while those containing $60 \mathrm{wt} \%$ or more resin suffered severe cracking. on the basis of this criteria, a practical waste loading of 30 wt\% dry ion exchange resins is recommended for solidification in polyethylene.

Swelling and cracking of cement waste forms containing ion exchange resins is well documented. As a result, some reactors solidify resins only in small quantities, along with other routine waste streams such as evaporator concentrates 37 . Solidification of approximately $7 \mathrm{wt} \%$ resins in cement (approximately 49 lbs dry resin/55 gallon drum size waste form) at some plants is reported in the literature.31. Previous waste form development studies indicate that a maximum of approximately 13 dry wt\% mixed bed ion exchange resins (approximately 91 ibs dry resin/55 gallon drum size waste form) can be solidified in portland type III cement and successfully withstand a two week water immersion test 12 . By way of comparison, $30 \mathrm{wt} \%$ mixed bed ion exchange 
resin solidified in polyethylene would yield approximately 139 lbs of dry resin/55 gallon drum size waste form. This represents improvements of $183 \%$ and 52\% over the 7 wt\% and 13 wt\% loadings in cement, respectively.

Optimal recommended waste loadings for polyethylene which, in some cases reflect a compromise between solidification efficiency and waste form performance, are summarized in Table 7.1.

Although polyethylene is not a new material, its application as a potential solidification agent had not been fully demonstrated. Thus, riuch of the work performed for this investigation focussed on the development of processing information. Progress and accomplishments in this area are summarized below:

- Extrusion is the optimal processing method for incorporating LLW in polyethylene. It is a reliable, proven technology which has the ability to incorporate large quantities of waste to form a homogeneous mixture.

- Feeding of dry waste and polyethylene binder materials is effectively accomplished by use of separate, auger-feeders which prevent settling and provide precise, reproducible metering.

- Process control parameters are specific to both waste type and the quantity of a particular waste to be incorporated. Manipulation of these parameters within a finite operating range is essential for successful waste form production. Optimal process control factors for each waste and polyethylene type investigated have been defined.

- A number of commercially available polyethylenes may be used for LLW encapsulation. Those materials with a higher melt index have better flow characteristics and may allow higher waste loadings.

A number of conclusions may be drawn as a result of this investigation. On the basis of laboratory scale process development and property evaluation studies, polyethylene has been shown to be a viable option for the improved solidification of low-level radioactive wastes. Its properties are particularly well suited for the incorporation of wastes resulting from advanced volume reduction technologies. Improvements in the solidification of ion exchange resins wich are solidified at poor efficiencies using contemporary agents have been demonstrated. Some of the specific advantages in the application of polyethylene for LLW solidification are summarized by the following points:

- Polyethylene is compatible with a range of LLW types, including evaporator concentrate salts (sodium sulfate and boric acid), incinerator ash, and ion exchange resins.

- As a thermoplastic material, polyethylene is not dependent upon chemically induced curing, and thus solidification of the waste-binder mixture is assured. 
Table 7.1

Comparison of Opt imal Recommended Waste Loadings in Polyethylene and Hydraul ic Cement Based on Process Control and Haste Form Performance Considerations

\begin{tabular}{|c|c|c|c|c|c|c|c|c|c|c|c|}
\hline & \multirow[b]{2}{*}{$\begin{array}{l}\text { Waste } \\
\text { Iype }\end{array}$} & \multicolumn{3}{|c|}{$\begin{array}{l}\text { Solidification in(a) } \\
\text { Polyethylene }\end{array}$} & \multicolumn{3}{|c|}{$\begin{array}{l}\text { Typical Sol idification(b) } \\
\text { in Hydraulic Cement }\end{array}$} & \multicolumn{3}{|c|}{$\begin{array}{l}\text { Maximum Sol idification(c) } \\
\text { in Hydraulic Cement }\end{array}$} & \multirow{2}{*}{$\begin{array}{l}\text { Percent Improvenent } \\
\text { by Polyethylene } \\
\text { Solidification (d) }\end{array}$} \\
\hline & & $\begin{array}{l}\text { Wt \% } \\
\text { Waste }\end{array}$ & $\begin{array}{l}\text { Drum Wt, } \\
\mathrm{kg} \text { (1bs) }\end{array}$ & $\begin{array}{l}\text { Waste/Drum, (e) } \\
\mathrm{kg} \text { (10s) }\end{array}$ & $\begin{array}{l}\text { Wt } \% \\
\text { Waste }\end{array}$ & $\begin{array}{l}\text { Drum Wt } \\
\mathrm{kg}(1 \mathrm{bs})\end{array}$ & $\begin{array}{l}\text { Waste/Drum, (e) } \\
\mathrm{kg} \text { (1bs) }\end{array}$ & $\begin{array}{l}\text { Wt } q \\
\text { Waste }\end{array}$ & $\begin{array}{l}\text { Drum wt, } \\
\mathrm{kg} \text { (1bs) }\end{array}$ & $\begin{array}{l}\text { Waste/Drum, (e) } \\
\mathrm{kg} \text { (1bs) }\end{array}$ & \\
\hline & $\begin{array}{l}\text { Sodiun } \\
\text { Sulfate }\end{array}$ & 70 & $\begin{array}{c}358 \\
(789)\end{array}$ & $\begin{array}{c}250 \\
(552)\end{array}$ & 12 & $\begin{array}{c}310 \\
(683)\end{array}$ & $\begin{array}{l}37 \\
(82)\end{array}$ & 9 & $\begin{array}{c}307 \\
(678)\end{array}$ & $\begin{array}{l}28 \\
(61)\end{array}$ & 805 \\
\hline 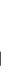 & $\begin{array}{l}\text { Boric } \\
\text { Acid }\end{array}$ & 50 & $\begin{array}{c}225 \\
(496)\end{array}$ & $\begin{array}{c}113 \\
(248)\end{array}$ & 5 & $\begin{array}{c}299 \\
(660)\end{array}$ & $\begin{array}{c}15 \\
(33)\end{array}$ & 15 & $\begin{array}{c}296 \\
(653)\end{array}$ & $\begin{array}{c}44 \\
(98)\end{array}$ & 153 \\
\hline 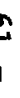 & $\begin{array}{l}\text { Incinerator } \\
\text { Ash }\end{array}$ & 40 & $\begin{array}{c}270 \\
(595)\end{array}$ & $\begin{array}{c}108 \\
(238)\end{array}$ & $\mathrm{NA}_{\mathrm{A}}(f)$ & $N A$ & NA & 40 & $\begin{array}{c}318 \\
(700)\end{array}$ & $\begin{array}{l}127 \\
(280)\end{array}$ & -18 \\
\hline & $\begin{array}{l}\text { Ion Exchange } \\
\text { Resin }\end{array}$ & 30 & $\begin{array}{l}210 \\
(463)\end{array}$ & $\begin{array}{c}63 \\
(139)\end{array}$ & 7 & $\begin{array}{c}318 \\
(700)\end{array}$ & $\begin{array}{c}22 \\
(49)\end{array}$ & 13 & $\begin{array}{c}318 \\
(700)\end{array}$ & $\begin{array}{l}41 \\
(91)\end{array}$ & 52 \\
\hline
\end{tabular}

a) Based on dry solid weight

b) Based on actual plant data and information reported in the literature

c) Based on previous BNL waste form development studies for waste forms which satisfied free-standing mono-

lithic solid and two week water immersion criteria

d) Bạsed on comparison of laboratory scale waste as specified in (c)

e) Equivalent quantity of waste solidified in a 55 gallon drum

f) Not applicable 
- Dramatic improvements in solidification efficiency, i.e., the quantity of waste incorporated in the waste form, are possible when compared on a equivalent basis with cement.

- Polyethylene solidified waste forms have good mechanical properties and performed well in property evaluation testing. With the exception of waste forms containing $\geq 50 \mathrm{wt} \%$ ion exchange resins, little effect due to 90 days of water immersion was observed. Polyethylene specimens easily withstood 100 psi compressive loads with minimal distortion. Thermal cycling did not produce any significant alteration in structural integrity or defomation resistance.

- Leach rates for polyethyl ene waste forms depend upon waste type and loading, but in general polyethylene leachability is low.

- When considering transportation, disposal, operating and associated volume reduction costs, the solidification of volume reduction wastes in polyethylene can provide a significant savings when compared to solidification of aqueous wastes in hydraulic cement.

Future research and development efforts will be directed at demonstrating polyethylene solidification system feasibility on a scale approximate to that required in actual operation. Variations in parametric requirements for the operation of a demonstration scale facility will be established, and system reliability confimed. 


\section{REFERENCES}

1. Kalb, P.D. and P. Col ombo, Selection of Improved Solidification Agents for Further Investigation, BNL-33404, Brookhaven National Laboratory, Upton, NY, February 1983.

2. Colombo, P., P.D. Kalb and M. Fuhmann, Waste Form Development Program Annual Report, BNL-51756, Brockhaven National Laboratory, UF+.on, NY, September 1983.

3. Fitzgerald, C.L., H.W. Godbee, R.E. BT anco and W. Davis, J.., "The Feasibility of Incorporating Radioactive Wastes in Asphalt or Polyethylene," Nuclear Applications and Technology, Vol. 9, December 1970.

4. Moriyama, N., S. Dojiri and H. Matsuzura, "Incorporation of an Evaporator Concentrate in Polyethylene for a BWR," Nuclear and Chemical Waste Management, Vol. 3, 1982 .

5. Moriyama, N., S. Dojiri and S. Emura, "Incorporation of Spent Ion Exchange Resins in Plastics," Journal of Nuclear Science and Technology, Vol. 12, No. 6, June 1977.

6. Oak Ridge National Laboratory, Spent Fuel and Radioactive Inventories and Projections, DOE/NE-0017/2, ORNL, Oak Ridge, TN, September 1983.

7. USNRC, "Licensing Requirements for Land Disposal of Radioactive Waste," Title 10 of the Code of Federal Regulations, Part 61, US Nuclear Regulatory Commission, Washington, DC, May 1983.

8. Fuhrmann, M. and P. Colombo, Selection of Waste Types for Use With Improved Agents, BNL-33405, Brookhaven National Laboratory, Upton, NY, Apri1 1983.

9. Kalb, P.D. and P. Colombo, "A Economic Analysis of a Fluidized-Bed Volume Reduction System," American Nuclear Society Transactions, Vol. 46, 1984 Annual Meeting, New Orleans, LA, June 1984.

10. Dlouhy, Z., Disposal of Radioactive Wastes, Studies in Environmental Science, Vol. 15, Elsevier Scientific Publishing Co., Amsterdam, The Netherlands, 1982.

11. Mullarkey, T.B., T.L. Jentz, J.M. Connelly, and J.P. Kane, A Survey and Evaluation of Handling and Disposing of Solid Low-Level Nuclear Cycle Wastes, AIF/NESP-008, NUS Corporation, Rockville, Maryland, 1976.

12. Neilson, R.M., Jr., P.D. Kalb, M. Fuhrmann and P. Colombo, "Sol idification of Ion Exchange Resin Wastes in Hydraul ic Cement," Publ ished in The Treatment and Handling of Radioactive Wastes, A.G. Blasewitz, J.M. Davis, M.R. Smith, ed., Springer-Verlag, New York, 1983. 
REFERENCES (cont.)

13. Schumann, R.C., "Polyethylene," Modern Plastics Encyclopedia, Vol. 52, No. $10 \mathrm{~A}$, J. Agranoff, ed., McGraw-Hill Publications Co., New York, October 1975.

14. Henkel, R.N., "Pol yethylene and Ethylene Copolymers," Moden Plastics Encyclopedia, Vol. 61, No. 10A, J. Agranoff, ed., McGraw-Hill Publications Co., New York, October 1984.

15. Barnhart, W.S., "Polymer Structure and Properties," Polymer Processing, Chemical Engineering Progress Symposium Series, No. 49, Vol. 60, American Institute of Chemical Engineers, New York, 1964.

16. Neilson, R.M., Jr., and P. Col ombo, Waste Form Development Program Annual Progress Report, BNL-51614, Brookhaven National Laboratory, Upton, NY, September 1982 .

17. Simonds, H.R., A.J. Weith and W. Schack, Extrusion of Plastics, Rubber and Metal, Reinhold Publishing Corp., New York, 1952.

18. Haisser, A.S., "Extrusion," Modern Plastics Encyclopedia, Vol. 61, No. 10A, J. Agranoff, ed., McGraw-Hill Publications Co., New York, October 1984.

19. Killion Model KL-125, Manufacturer's Specifications, Killion Extruders, Inc., Verona, NJ, 1983.

20. Accu-Rate Model 300, Manufacturer's Specifications, Whitewater, WI, 1987.

21. Chatfield, C., Statistics for Technology, A Course in Applied Statistics, Halstead Press, J. Wiley and Sons, New York, 1978.

22. Colombo, P., M. Fuhmann and S. Levine, Preliminary Waste Form Evaluation Criteria, BNL-33403, Brookhaven National Laboratory, Upton, NY, December 1982.

23. USNRC, "Technical Position on Waste Form," US Nuclear Regulatory Commission, Low-level Waste Licensing Branch, Washington, DC, May 1983.

24. Zhou, H. and P. Colombo, "Sol idification of Radioactive Waste in a Cement Lime Mixture," Waste Isolation in the U.S., Technical Programs and Public Education, Vol. 2, Low-Level Waste, Volume Reduction Methodologies and Economics, Proceedings of Waste Management '84, Tucson, AZ, March 1984.

25. Neilson, R.M., Jr., and P. Colombo, Solidification of Ion Exchange Resin Wastes, BNL-51615, Brookhaven National Laboratory, Upton, NY, August 1982. 


\section{REFERENCES (cont.)}

26. Manufacturer's Product Data Sheets and Personal Communication with Technical Service Dept. $(10 / 29 / 84)$, Gulf 0 il Chemicals Co., Plastics Division, U.S. Operations, Houston, TX.

27. ASTM, Standard Method of Test for Compressive Strength of Cylindrical Concrete Specimens, C39-72, American Society for resting and Materials, Philadelphia, PA, 1975.

28. ASTM, Standard Method of Test for Deformation of Plastics Under Load, D-621, American Society for Testing and Materials, Philadelphia, PA, 1964.

29. ASTM, Standard Method of Test for Thermal Cycling of Electroplated Plastics, B-553, American Society for Testing and Materials, Philadelphia, PA, 1979.

30. ANS Standards Committee, Horking Group 16.1, Measurement of the Leachability of Solidified Low-Level Wastes, American Nuclear Society, June 1984.

31. Triglio, G., Volume Reduction Techniques in Low-Level Radioactive Waste Management, prepared for Division of Waste Management, USNRC by Teknekron, Inc., Berkeley, CA, September 1981.

32. Kalb, P.D. and P. Colombo, An Economic Analys is of Volume Reduction/ Polyethylene Solidification of LLW, BNL-51866, Brookhaven National Laboratory, January 1984.

33. EPRI, TAG, Technical Assessment Guide, P-2410-SR, Technical Evaluation Group of EPRI PIanning and Evaluation Division, Electric Power Research Institute, Palo Alto, CA, May 1982.

34. Kalb, P.D. and P. Colombo, Full Scale Leaching of Commercial Reactor Waste Forms - Final Report, BNL.-35561, Brookhaven National Laboratory, Upton, NY, Sept ember 1984.

35. Zhou, H. and P. Colombo, "Solidification of Radioact ive Wastes in Masonry Cement," Paper presented at the 1984 Fall Convention of the American Concrete Institute, New York, NY, 10/28-11/2, 1984.

36. Colombo, P., P.D. Kalb, P. Kemeny, and H. Zhou, Acquisition and Analysis of Radioactive Waste Forms and Waste Streams From a Pressurized Water Reactor, BNL-33695, Brookhaven National Laboratory, Upton, NY, September 1983.

37. Neilson, R.M., Jr., P.D. Kalb and P. Colombo, Lysimeter Study of Commercial Reactor Waste Forms: Waste Form Acquisition, Characterization, and FulT-Scale Leaching, BNL-51613, Brookhaven National Laboratory, Upton, NY, September 1982. 


\section{;}

Appendix A

Feeder and Extruder Rate Calibration Data 
Tabie A-1

Statistical Data for Feeder Calibration of Sodium Sulfate(a)

Feeder Set

Speed, \% max.

\section{Mean}

Output, $\mathrm{g} / \mathrm{sec}$
Absolute

Error

(b) Percent

(b) Error (c)

$\begin{array}{rlll}25 & 0.7051 & 0.0145 & 2.1 \\ 40 & 1.1176 & 0.0863 & 7.7 \\ 50 & 1.4642 & 0.0497 & 3.4 \\ 60 & 1.5173 & 0.0544 & 3.5 \\ 75 & 2.2833 & 0.0396 & 1.7 \\ 100 & 2.9223 & 0.1634 & 5.6\end{array}$

\footnotetext{
(a) Based on 5 replicate trials

(b) $E= \pm t_{1 / 2} \alpha, n-1 \frac{S}{n^{1 / 2}}$ at $95 \%$ confidence interval (see Sec. 4.4.1)

(c) $\% E=E /$ Mean
} 


\section{Table A-2}

Statistical Data for Feeder Calibration of Boric Acid(a)

\begin{tabular}{clll}
$\begin{array}{l}\text { Feeder Set } \\
\text { Speed, } \% \text { max. }\end{array}$ & $\begin{array}{l}\text { Mean } \\
\text { Output, } \\
\text { g/sec }\end{array}$ & $\begin{array}{l}\text { Absolute } \\
\text { Error }\end{array}$ & $\begin{array}{l}\text { Percent } \\
\text { Error }\end{array}$ \\
\hline 20 & 0.2524 & 0.0237 & 9.4 \\
30 & 0.4853 & 0.0266 & 5.4 \\
40 & 0.7391 & 0.0326 & 4.4 \\
50 & 0.8884 & 0.0305 & 3.4 \\
60 & 1.1113 & 0.0303 & 2.7 \\
70 & 1.2772 & 0.0460 & 3.6 \\
80 & 1.5878 & 0.0406 & 3.2 \\
90 & 1.7594 & 0.0428 & 2.4 \\
100 & 1.8528 & 0.1000 & 5.4
\end{tabular}

\footnotetext{
(a) Based on 5 replicate trials

(b) $E= \pm t_{1 / 2 \alpha}, n-1 \frac{S}{n 1 / 2}$ at $95 \%$ confidence interval (see Sec. 4.4.1) (c) $\% E=E /$ Mean
} 


\section{Table A-3}

Statistical Data for Feeder Calibration of Incinerator Ash(a)

$\begin{array}{cccc}\begin{array}{l}\text { Feeder Set } \\ \text { Speed, } \% \text { max. }\end{array} & \begin{array}{l}\text { Mean } \\ \text { Output, } \\ \text { g/sec }\end{array} & \begin{array}{l}\text { Absolute } \\ \text { Error }\end{array} & \begin{array}{l}\text { Percent } \\ \text { Error }\end{array}(c) \\ & & & \\ 20 & 0.0937 & 0.0023 & 3.0 \\ 30 & 0.1854 & 0.0044 & 3.0 \\ 40 & 0.2587 & 0.0054 & 2.6 \\ 50 & 0.3154 & 0.0083 & 3.3 \\ 60 & 0.3659 & 0.0119 & 4.0 \\ 70 & 0.4103 & 0.0045 & 1.4 \\ 80 & 0.4582 & 0.0078 & 2.1 \\ 90 & 0.5049 & 0.0047 & 0.9\end{array}$

\footnotetext{
(a) Based on 5 replicate trials

(b) $E= \pm t_{1 / 2 \alpha}, n-1 \frac{S}{n^{1 / 2}}$ at $95 \%$ confidence interval (see Sec. 4.4.1)

(c) $q_{E}=E /$ Mean
} 
Table A-4

Statistical Data for Feeder Calibration of Ion Exchange Resin(a)

\begin{tabular}{cccc}
$\begin{array}{l}\text { Feeder Set } \\
\text { Speed, } \% \text { max. }\end{array}$ & $\begin{array}{l}\text { Mean } \\
\text { Output, } \\
\text { g/sec }\end{array}$ & $\begin{array}{l}\text { Absolute } \\
\text { Error }\end{array}$ & $\begin{array}{l}\text { Percent } \\
\text { Error }\end{array}$ \\
\cline { 1 - 1 } 10 & 0.2499 & 0.0030 & 1.2 \\
20 & 0.5119 & 0.0107 & 2.1 \\
30 & 1.0030 & 0.0043 & 0.4 \\
40 & 1.3817 & 0.0095 & 0.7 \\
50 & 1.7605 & 0.0119 & 0.7 \\
60 & 2.1446 & 0.0173 & 0.8 \\
70 & 2.5084 & 0.0108 & 0.4 \\
80 & 2.8793 & 0.0242 & 0.8 \\
90 & 3.2034 & 0.0380 & 1.2 \\
100 & 3.4655 & 0.0681 & 1.9
\end{tabular}

\footnotetext{
(a) Based on 5 repl icate trials

(b) $E= \pm t_{1 / 2 \alpha}, n-1 \frac{S}{n^{1 / 2}}$ at $95 \%$ confidence interval (see Sec. 4.4.1)

(c) $q E=E /$ Mean
} 
Table A-5

Statistical Data for Feeder Calibration of Low Density Polyethylene(a)

\begin{tabular}{|c|c|c|c|}
\hline $\begin{array}{l}\text { Foofer Set } \\
\text { Speed, \% max. }\end{array}$ & $\begin{array}{l}\text { Mean } \\
\text { Output, } \\
\text { g/sec }\end{array}$ & $\begin{array}{l}\text { Absolute } \\
\text { Error (b) }\end{array}$ & $\begin{array}{l}\text { Percent } \\
\text { Error (c) }\end{array}$ \\
\hline 5 & 0.1911 & 0.0037 & 1.9 \\
\hline 10 & 0.4778 & 0.0084 & 1.8 \\
\hline 20 & 1.0222 & 0.0174 & 1.7 \\
\hline 30 & 1.5409 & 0.0086 & 0.6 \\
\hline 40 & 2.0737 & 0.0241 & 1.2 \\
\hline 50 & 2.6166 & 0.0346 & 1.3 \\
\hline 60 & 3.1578 & 0.0159 & 0.5 \\
\hline 70 & 3.6760 & 0.0307 & 0.8 \\
\hline 80 & 4.1936 & 0.0674 & 1.6 \\
\hline 90 & 4.8286 & 0.0732 & 1.5 \\
\hline 100 & 5.1941 & 0.0654 & 1.3 \\
\hline
\end{tabular}

(a) Based on 5 repl icate trials

(b) $E= \pm t_{1 / 2 a} n-1 \frac{S}{n 1 / 2}$ at $95 \%$ confidence interval (see Sec. 4.4.1)

(c) $\alpha E=E /$ Mean 


\section{Table A-6}

Extruder Parameters for Output Calibration Runs

\begin{tabular}{|c|c|c|c|c|c|c|c|}
\hline \multirow[b]{2}{*}{$\begin{array}{l}\text { LDPE Type } \\
\text { (Melt Infex) }\end{array}$} & \multicolumn{4}{|c|}{$\begin{array}{l}\text { Temperature Control } \\
\text { Settings }{ }^{\circ} C,(O F)\end{array}$} & \multicolumn{3}{|c|}{ Instrumentation Readings } \\
\hline & $\begin{array}{c}\text { Zone } \\
1 \\
\end{array}$ & $\begin{array}{c}\text { Zone } \\
2 \\
\end{array}$ & $\begin{array}{c}\text { Zone } \\
3 \\
\end{array}$ & $\begin{array}{l}\text { Die } \\
\text { Zone } \\
\end{array}$ & $\begin{array}{l}\text { Melt } \\
\text { Temp.; } \\
\text { oc(of) }\end{array}$ & $\begin{array}{l}\text { Melt } \\
\text { Press } \\
\mathrm{MPa}_{2} \text { (psi) }\end{array}$ & $\begin{array}{l}\text { Screw } \\
\text { Speed, } \\
\text { RPM } \\
\end{array}$ \\
\hline $\begin{array}{c}\text { Gulf } 1117-B \\
(2.0)\end{array}$ & $\begin{array}{l}107 \\
(225)\end{array}$ & $\begin{array}{c}149 \\
(300)\end{array}$ & $\begin{array}{c}149 \\
(300)\end{array}$ & $\begin{array}{c}177 \\
(350)\end{array}$ & $\begin{array}{c}146 \\
(294)\end{array}$ & $\begin{array}{l}5.79-9.79 \\
(840-1420)\end{array}$ & $10-80$ \\
\hline
\end{tabular}




\section{Table A-7}

Statistica? Data for Extruder Output Calibration Runs(a)

\begin{tabular}{|c|c|c|c|c|}
\hline $\begin{array}{c}\text { Extruder } \\
\text { Screw Speed, } \\
\text { RPM } \\
\end{array}$ & $\begin{array}{l}\text { Mean } \\
\text { Output, } \\
\text { g/min }\end{array}$ & $\begin{array}{l}\text { Absolute } \\
\text { Error (b) }\end{array}$ & $\begin{array}{l}\text { Percent } \\
\text { Error (c) }\end{array}$ & $\begin{array}{l}\text { Mean } \\
\text { Output, } \\
\text { g/sec }\end{array}$ \\
\hline 10 & 12.158 & 0.415 & 3.4 & 0.203 \\
\hline 20 & 24.874 & 1.038 & 4.2 & 0.415 \\
\hline 30 & 37.114 & 0.853 & 2.3 & 0.619 \\
\hline 40 & 50.135 & 1.048 & 2.1 & 0.836 \\
\hline 50 & 64.296 & 1.737 & 2.7 & 1.072 \\
\hline 60 & 77.410 & 1.372 & 1.8 & 1.290 \\
\hline 70 & 89.696 & 1.595 & 1.8 & 1.494 \\
\hline 80 & 103.158 & 2.030 & 2.0 & 1.719 \\
\hline
\end{tabular}

(a) Based on 5 replicate trials

(b) $E= \pm t_{1 / 2 \alpha}, n-1 \frac{S}{n^{1 / 2}}$ at $95 \%$ confidence interval (see Sec. 4.4.1)

(c) $q E=E /$ Mean 


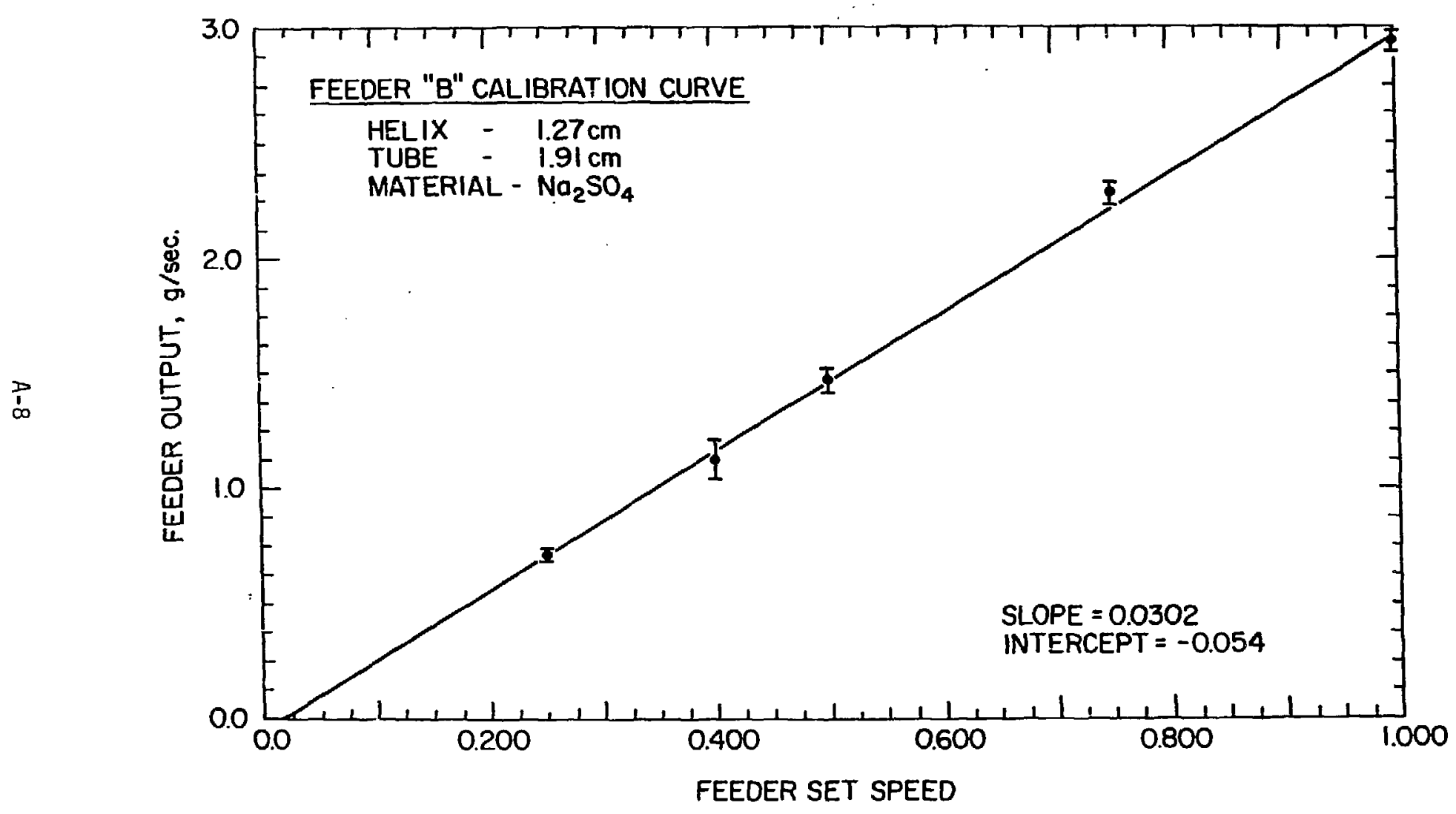

Figure A-1 Feeder output calibration curve for sodium sulfate. The mean output and associated error bars are plotted as a function of percent of maximum set speed $(\div 100)$. Linear regression line is shown with an $r^{2}=0.997$. 


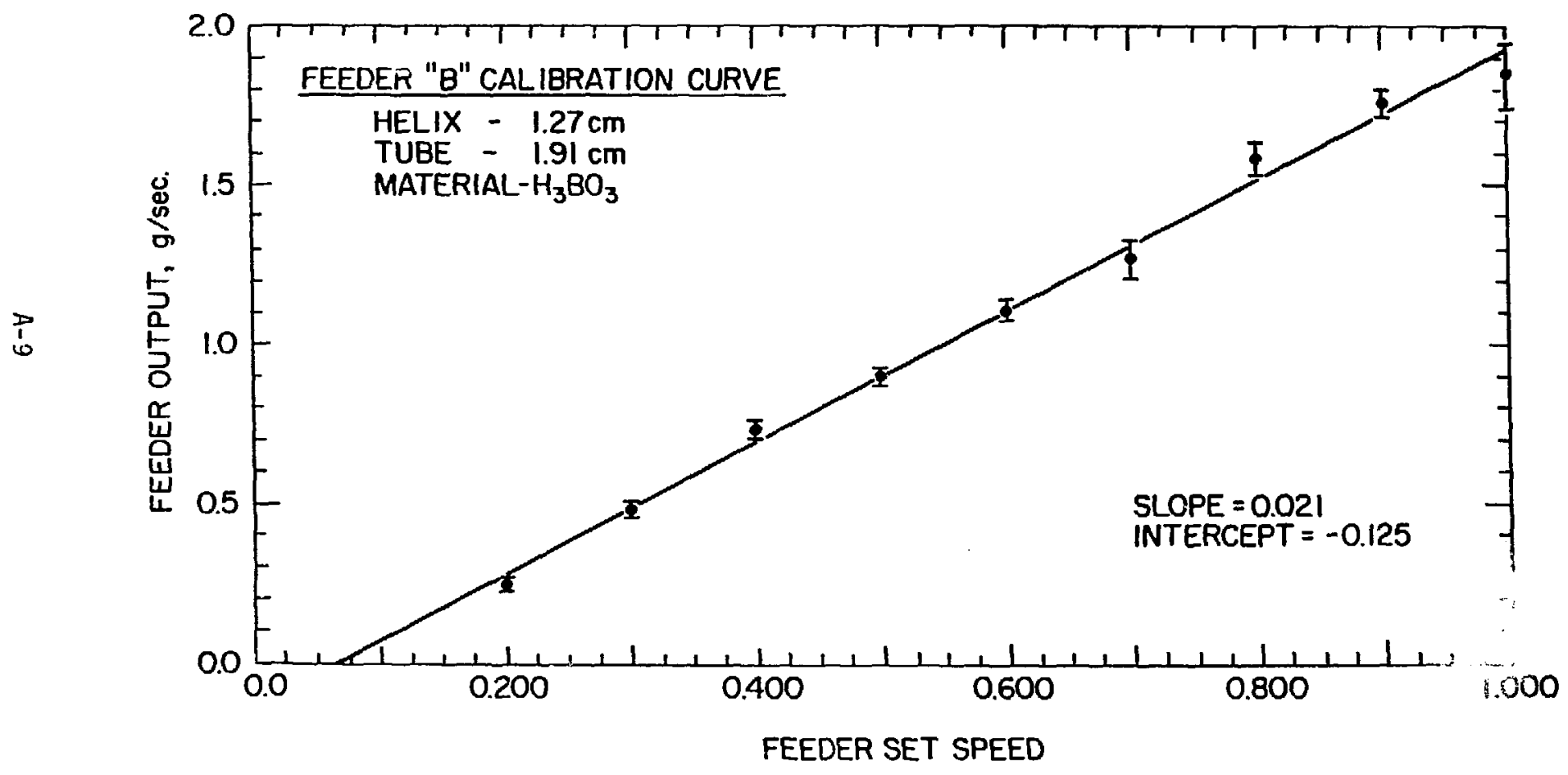

Figure A-2 Feeder output calibration curve for boric acid. The mean output and associated error bars are plotted as a function of percent of maximum set speed $(\div 100)$. Linear regression line is shown with an $r^{2}=0.993$. 


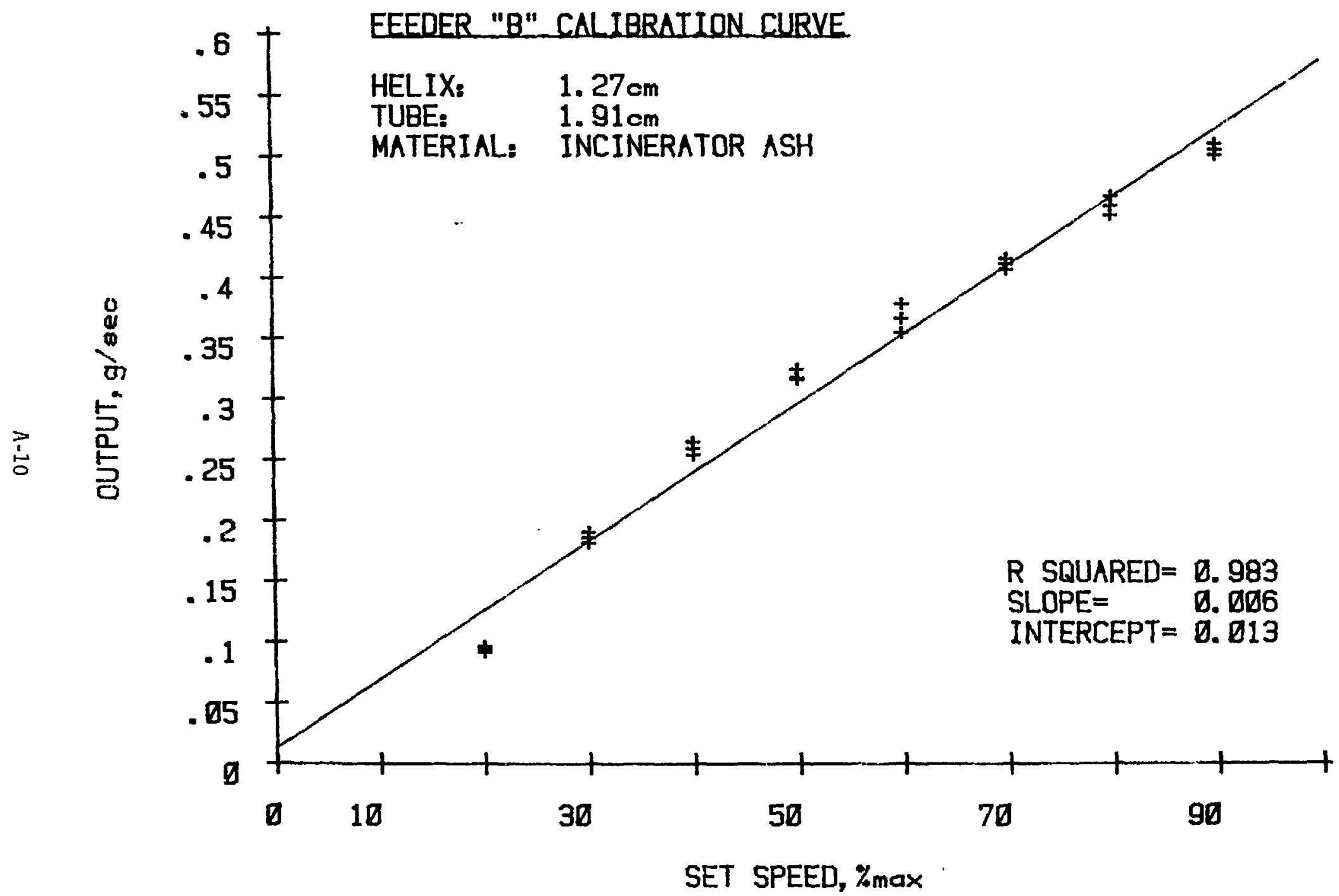

Figure A-3 Feeder output calibration curve for incinerator ash. The mean output and associated error bars are plotted as a function of percent of maximum set speed. 


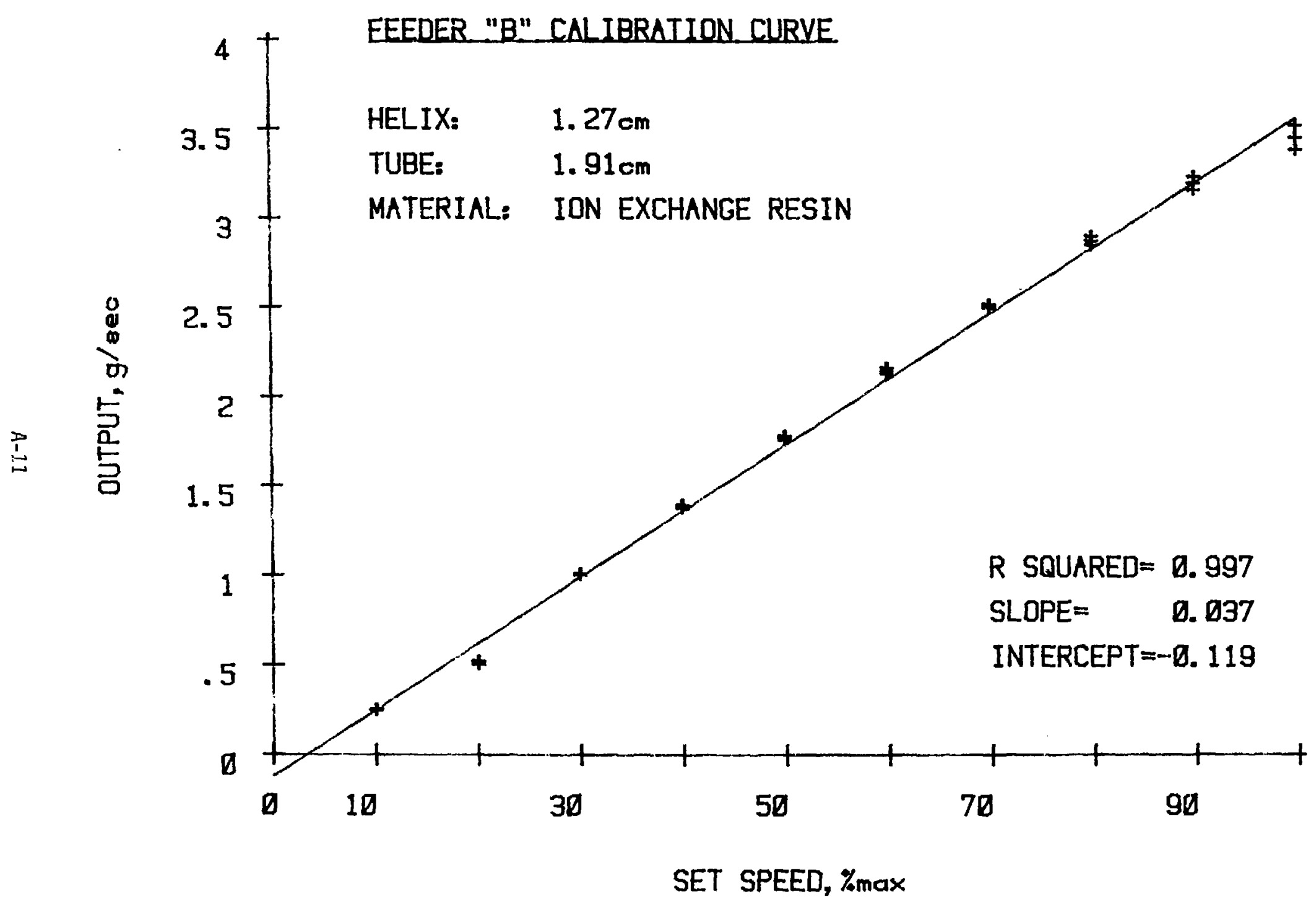

Figure A-4 Feeder output cal ibration curve for ion exchange resins. The mean output and
associated error bars are plotted as a function of percent of maximum set speed. 


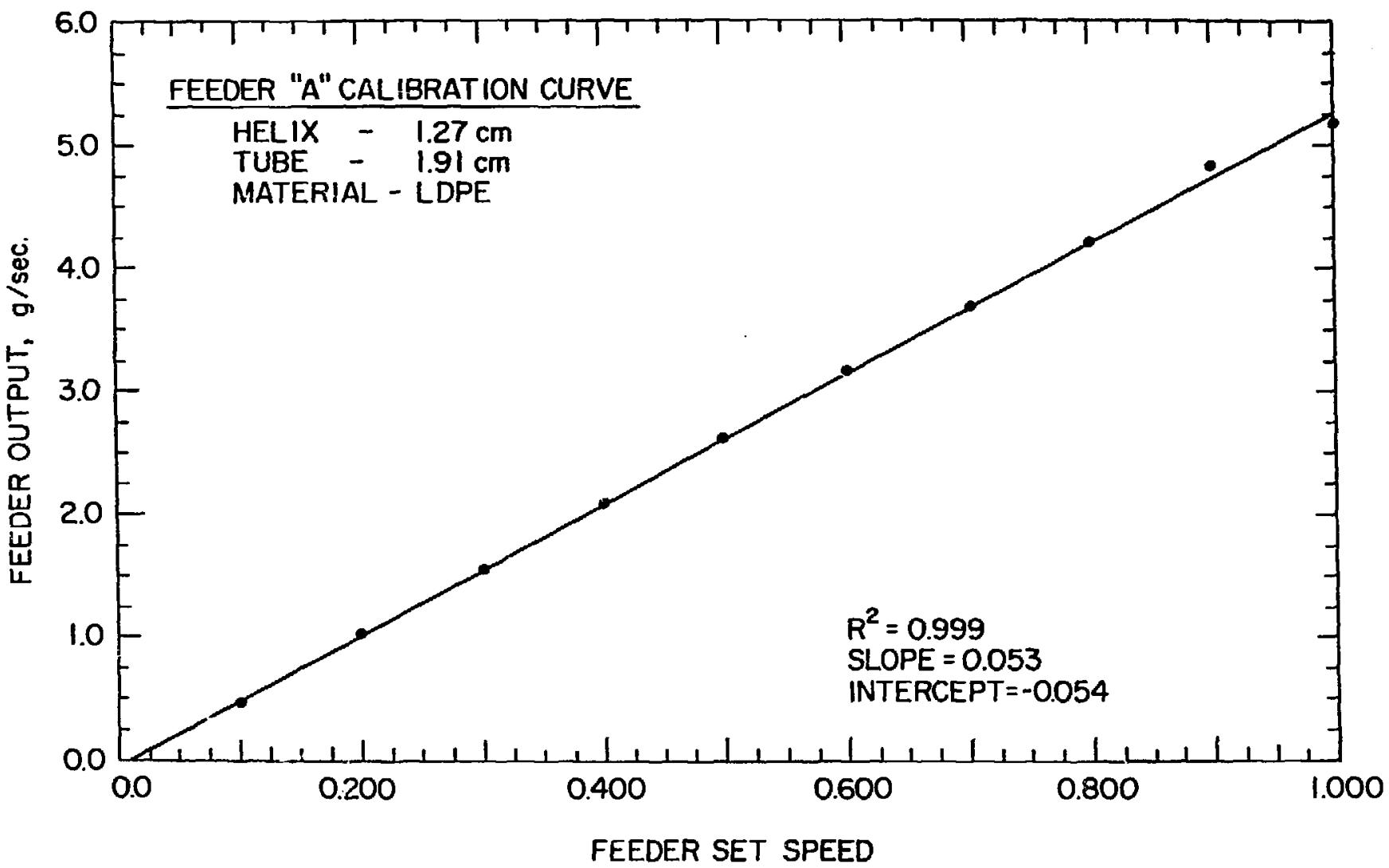

Figure A-5 Feeder output calibration curve for low density polyethylene. The mean output is ploited as a function of percent of maximum set speed $(\div 100)$. The average error is $<1.3 \%$, thus error bars are omitted. 


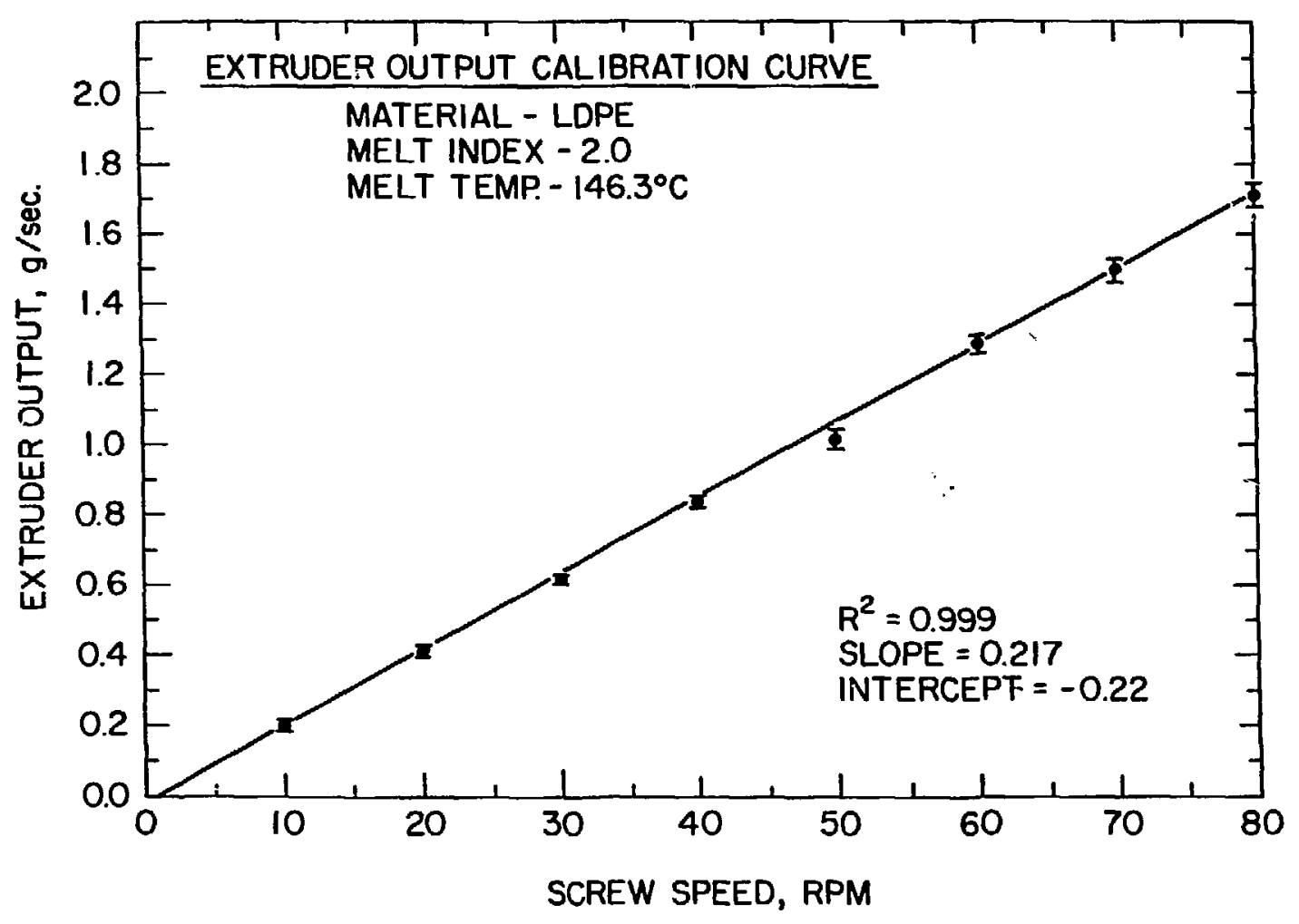

Figure A-6 Single screw extruder output as a function of screw speed. 
Appendix B

Extruder Temperature, Pressure and Rate Correlation Data 


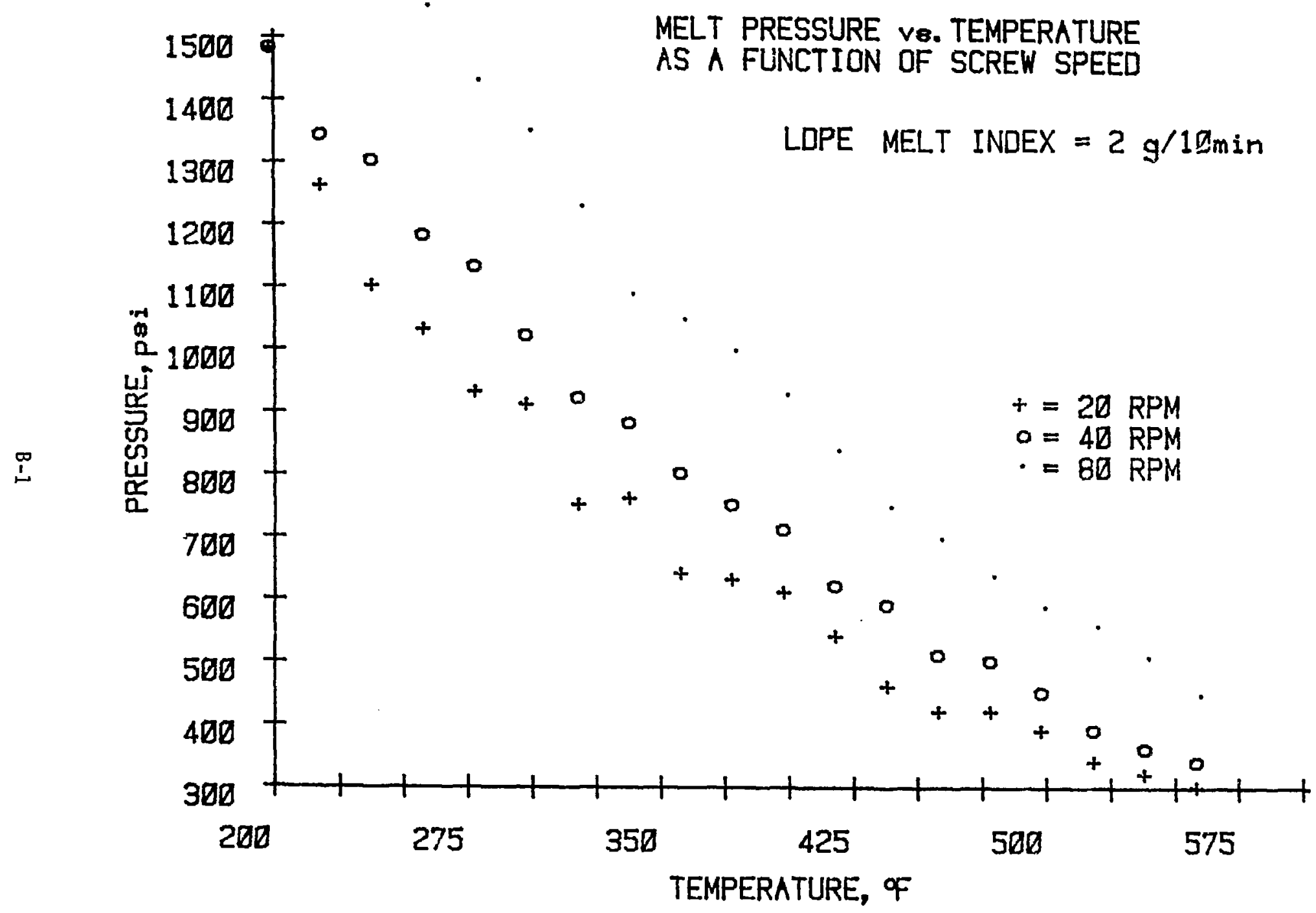

Figure B-1 The effects of increasing temperature on melt pressure as a function of extruder screw speed for a polyethylene with a melt index of $2.0 \mathrm{~g} / 10$ minutes. 


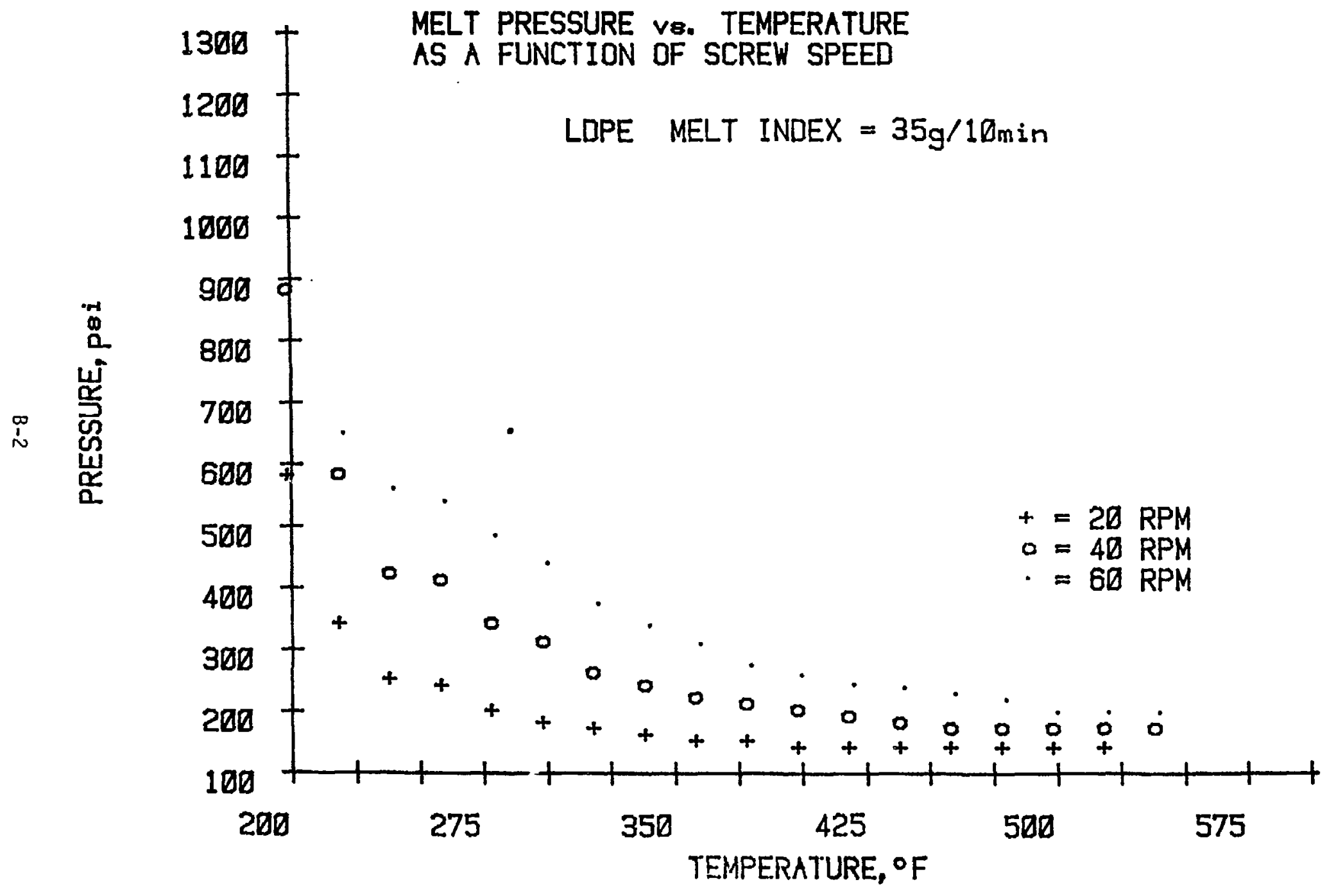

Figure B-2 The effects of increasing temperature on melt pressure as a function of extruder 


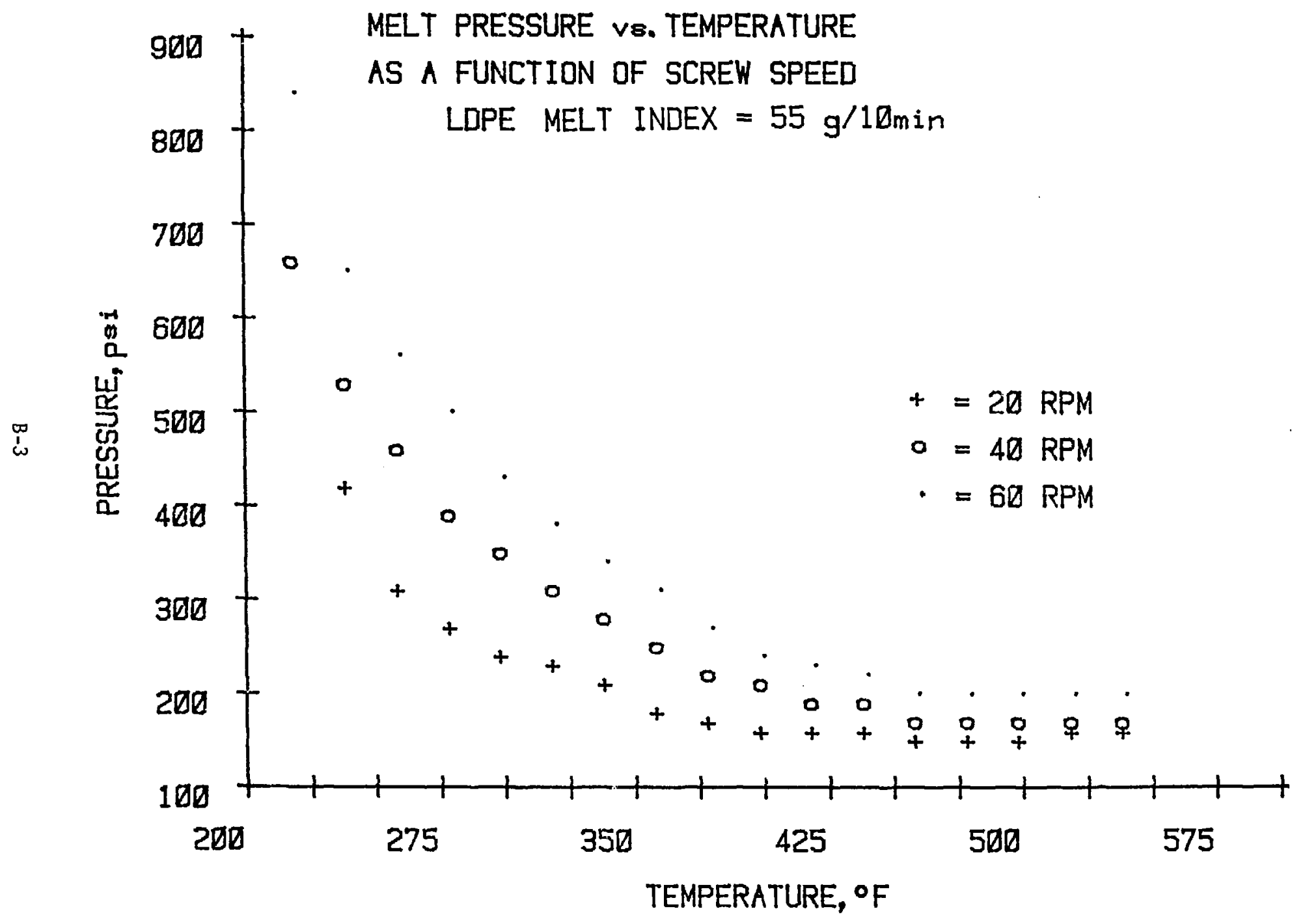

Figure B-3 The effects of increasing temperature on melt pressure as a function of extruder screw speed for a polyethylene with a melt index of $55.0 \mathrm{~g} / 10$ minutes. 


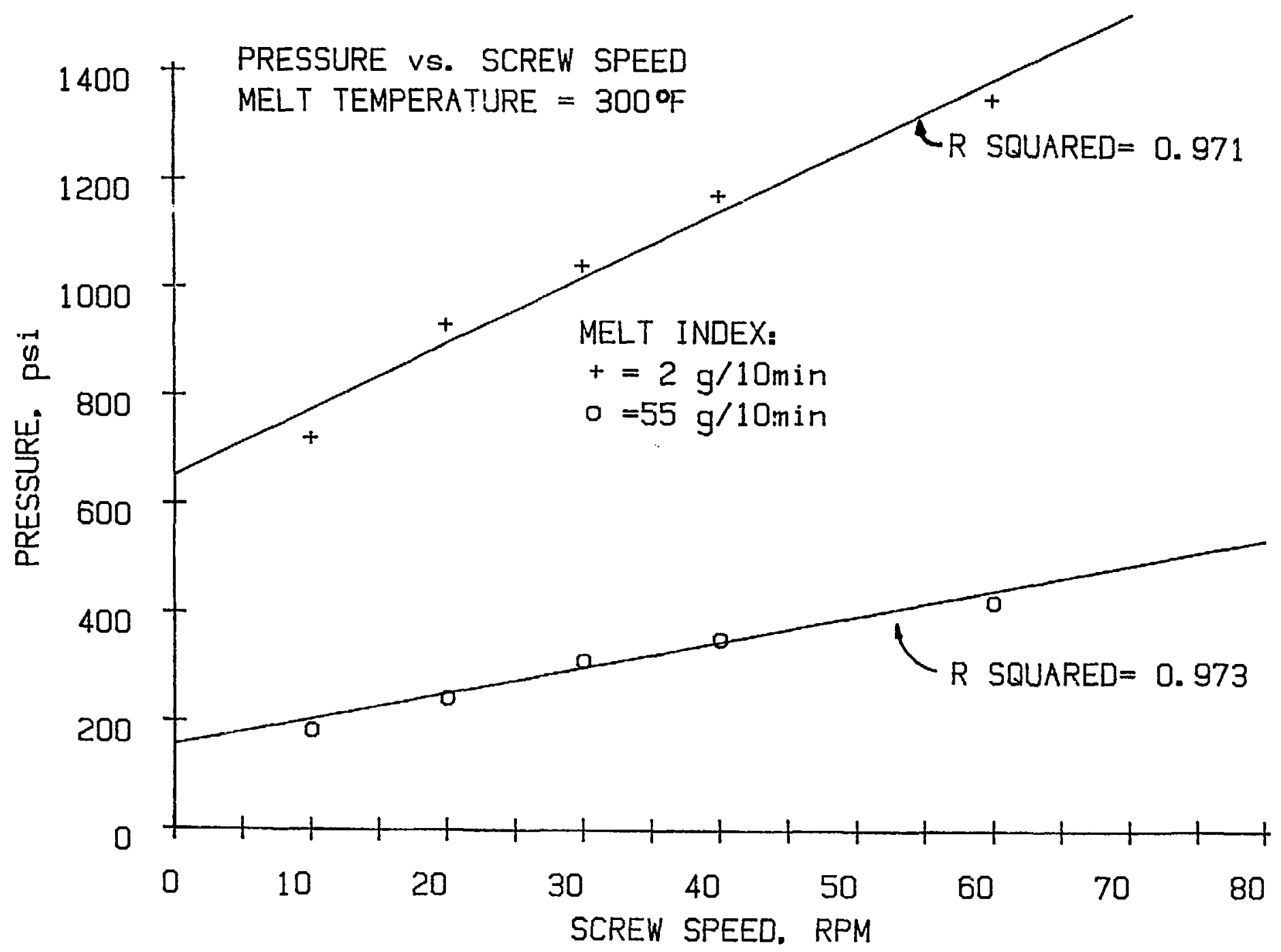

Figure B-4 Extruder melt pressure as a function of screw speed taken at a constant melt temperature of $300^{\circ} \mathrm{F}\left(149^{\circ} \mathrm{C}\right)$ for two polyethylenes with varying melt index characteristics. The straigth lines represent 1 inear regression analysis. 
Appendix C

Typical Extruder Parameters for LLW Sol idification 
Extruder Parameters for Selected Sodiun Sulfate Solidification Formulations

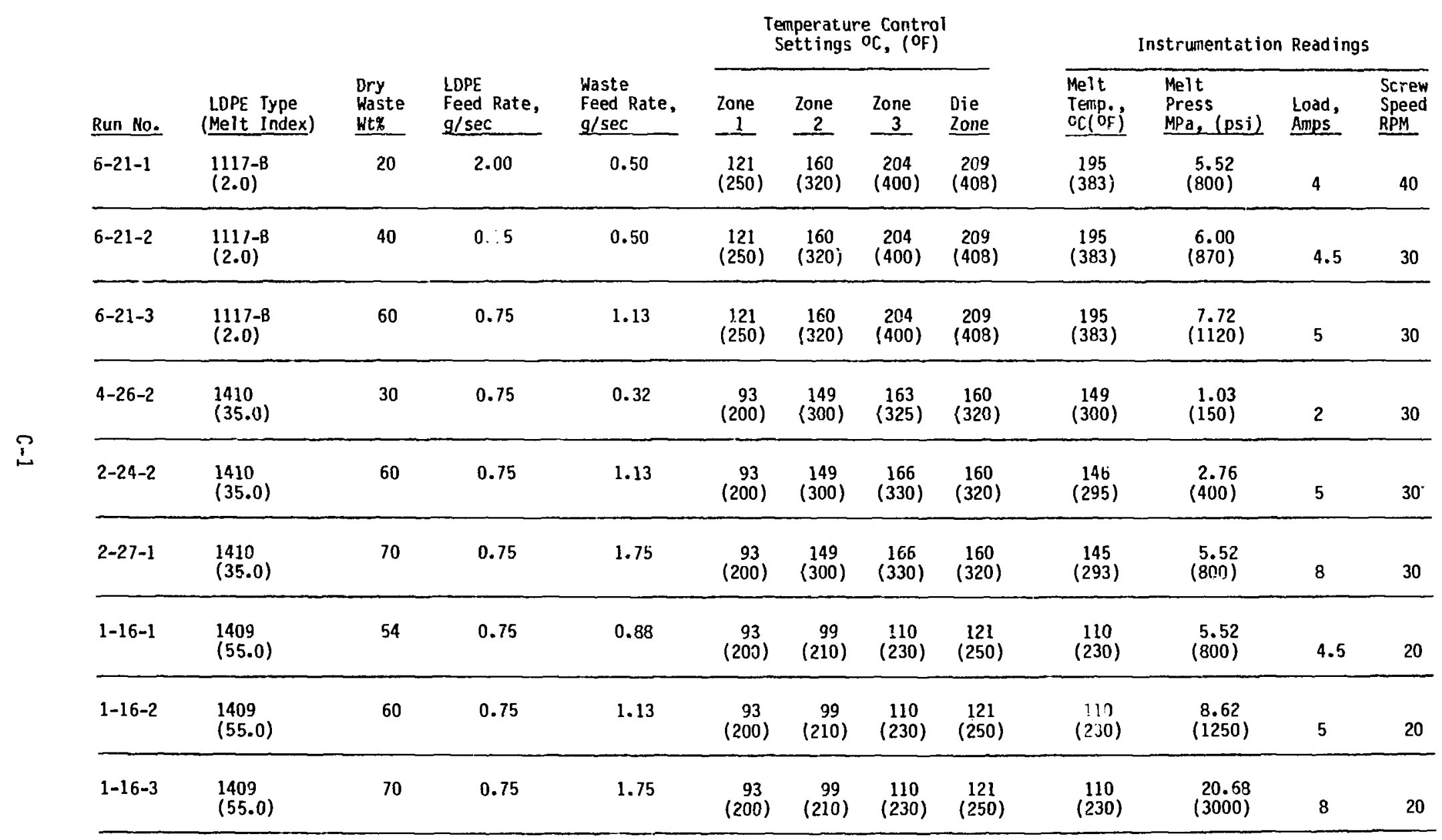


Extruder Parameters for Selected Boric Acid Sol idification Formulations

\begin{tabular}{|c|c|c|c|c|c|c|c|c|c|c|c|c|}
\hline \multirow[b]{2}{*}{ Run No. } & \multirow[b]{2}{*}{$\begin{array}{l}\text { LDPE Type } \\
\text { (Melt Index) }\end{array}$} & \multirow[b]{2}{*}{$\begin{array}{l}\text { Ory } \\
\text { Waste } \\
\text { Wt\% } \\
\end{array}$} & \multirow[b]{2}{*}{$\begin{array}{l}\text { LOPE } \\
\text { Feed Rate, } \\
\text { g/sec }\end{array}$} & \multirow[b]{2}{*}{$\begin{array}{l}\text { Waste } \\
\text { Feed Rate, } \\
\mathrm{g} / \mathrm{sec}\end{array}$} & \multicolumn{4}{|c|}{$\begin{array}{l}\text { Temperature Control } \\
\text { Settings }{ }^{\circ} \mathrm{C},(\mathrm{O})\end{array}$} & \multicolumn{4}{|c|}{ Instrumentation Readings } \\
\hline & & & & & $\begin{array}{c}\text { Zone } \\
1 \\
\end{array}$ & $\begin{array}{c}\text { Zone } \\
2 \\
\end{array}$ & $\begin{array}{c}\text { Zone } \\
3 \\
\end{array}$ & $\begin{array}{l}\text { Die } \\
\text { Zone } \\
\end{array}$ & $\begin{array}{l}\text { Melt } \\
\text { Temp.; } \\
\text { OC(아) }\end{array}$ & $\begin{array}{l}\text { Melt } \\
\text { Press } \\
\text { MPa, (psi) }\end{array}$ & $\begin{array}{l}\text { Load, } \\
\text { Amps }\end{array}$ & $\begin{array}{l}\text { Screw } \\
\text { Speed } \\
\text { RPM } \\
\end{array}$ \\
\hline $12-16-1$ & $\begin{array}{l}1117-8 \\
(2.0)\end{array}$ & 15 & 1.00 & 0.18 & $\begin{array}{c}93 \\
(200)\end{array}$ & $\begin{array}{c}121 \\
(250)\end{array}$ & $\begin{array}{c}143 \\
(290)\end{array}$ & $\begin{array}{c}149 \\
(300)\end{array}$ & $\begin{array}{c}143 \\
(289)\end{array}$ & $\begin{array}{c}8.62 \\
(1250)\end{array}$ & 4.5 & 20 \\
\hline $12-19-3$ & $\begin{array}{l}1117-8 \\
(2.0)\end{array}$ & 25 & 0.75 & 0.25 & $\begin{array}{c}118 \\
(245)\end{array}$ & $\begin{array}{c}121 \\
(250)\end{array}$ & $\begin{array}{c}149 \\
(300)\end{array}$ & $\begin{array}{l}149 \\
(300)\end{array}$ & $\begin{array}{c}146 \\
(295)\end{array}$ & $\begin{array}{c}9.65 \\
(1400)\end{array}$ & 4.8 & 10 \\
\hline $1 ?-21-4$ & $\begin{array}{l}1117-B \\
(2.0)\end{array}$ & 30 & 0.75 & 0.32 & $\begin{array}{c}118 \\
(245)\end{array}$ & $\begin{array}{c}121 \\
(250)\end{array}$ & $\begin{array}{c}149 \\
(300)\end{array}$ & $\begin{array}{c}149 \\
(300)\end{array}$ & $\begin{array}{c}149 \\
(300)\end{array}$ & $\begin{array}{l}11.72 \\
(1700)\end{array}$ & 4.8 & 10 \\
\hline $1-10-1$ & $\begin{array}{l}1410 \\
(35.0)\end{array}$ & 30 & 0.75 & 0.32 & $\begin{array}{c}93 \\
(200)\end{array}$ & $\begin{array}{c}99 \\
(210)\end{array}$ & $\begin{array}{c}110 \\
(230)\end{array}$ & $\begin{array}{c}121 \\
(250)\end{array}$ & $\begin{array}{c}110 \\
(230)\end{array}$ & $\begin{array}{r}4.14 \\
(600)\end{array}$ & 4.0 & 20 \\
\hline $1-10-2$ & $\begin{array}{l}1410 \\
(35.0)\end{array}$ & 35 & 0.75 & 0.40 & $\begin{array}{c}93 \\
(200)\end{array}$ & $\begin{array}{c}99 \\
(210)\end{array}$ & $\begin{array}{l}110 \\
(230)\end{array}$ & $\begin{array}{c}121 \\
(250)\end{array}$ & $\begin{array}{c}110 \\
(230)\end{array}$ & $\begin{array}{r}5.52 \\
(800)\end{array}$ & 4.0 & 15 \\
\hline $1-10-3$ & $\begin{array}{l}1410 \\
(35.0)\end{array}$ & 40 & 0.75 & 0.50 & $\begin{array}{c}93 \\
(200)\end{array}$ & $\begin{array}{c}99 \\
(210)\end{array}$ & $\begin{array}{c}110 \\
(230)\end{array}$ & $\begin{array}{c}121 \\
(250)\end{array}$ & $\begin{array}{c}110 \\
(230)\end{array}$ & $\begin{array}{c}7.58 \\
(1100)\end{array}$ & 4.0 & 15 \\
\hline $1-12-1$ & $\begin{array}{l}1409 \\
(55.0)\end{array}$ & 40 & 0.75 & 0.50 & $\begin{array}{c}93 \\
(200)\end{array}$ & $\begin{array}{c}99 \\
(210)\end{array}$ & $\begin{array}{l}110 \\
(230)\end{array}$ & $\begin{array}{c}121 \\
(250)\end{array}$ & $\begin{array}{l}110 \\
(230)\end{array}$ & $\begin{array}{r}4.83 \\
(700)\end{array}$ & 4.0 & 20 \\
\hline $1-13-1$ & $\begin{array}{l}1409 \\
(55.0)\end{array}$ & 45 & 0.75 & 0.61 & $\begin{array}{c}93 \\
(200)\end{array}$ & $\begin{array}{c}99 \\
(210)\end{array}$ & $\begin{array}{l}110 \\
(230)\end{array}$ & $\begin{array}{c}121 \\
(250)\end{array}$ & $\begin{array}{c}110 \\
(230)\end{array}$ & $\begin{array}{c}8.27 \\
(1200)\end{array}$ & 4.0 & 20 \\
\hline $1-13-2$ & $\begin{array}{l}1409 \\
(55.0)\end{array}$ & 50 & 0.75 & 0.75 & $\begin{array}{c}93 \\
(200)\end{array}$ & $\begin{array}{c}99 \\
(210)\end{array}$ & $\begin{array}{c}110 \\
(230)\end{array}$ & $\begin{array}{l}121 \\
(250)\end{array}$ & $\begin{array}{c}110 \\
(230)\end{array}$ & $\begin{array}{r}13.79 \\
(2009)\end{array}$ & 4.0 & 20 \\
\hline
\end{tabular}


Exiruder Parameters for Selected Incinerator Ash Solidification Fomulations

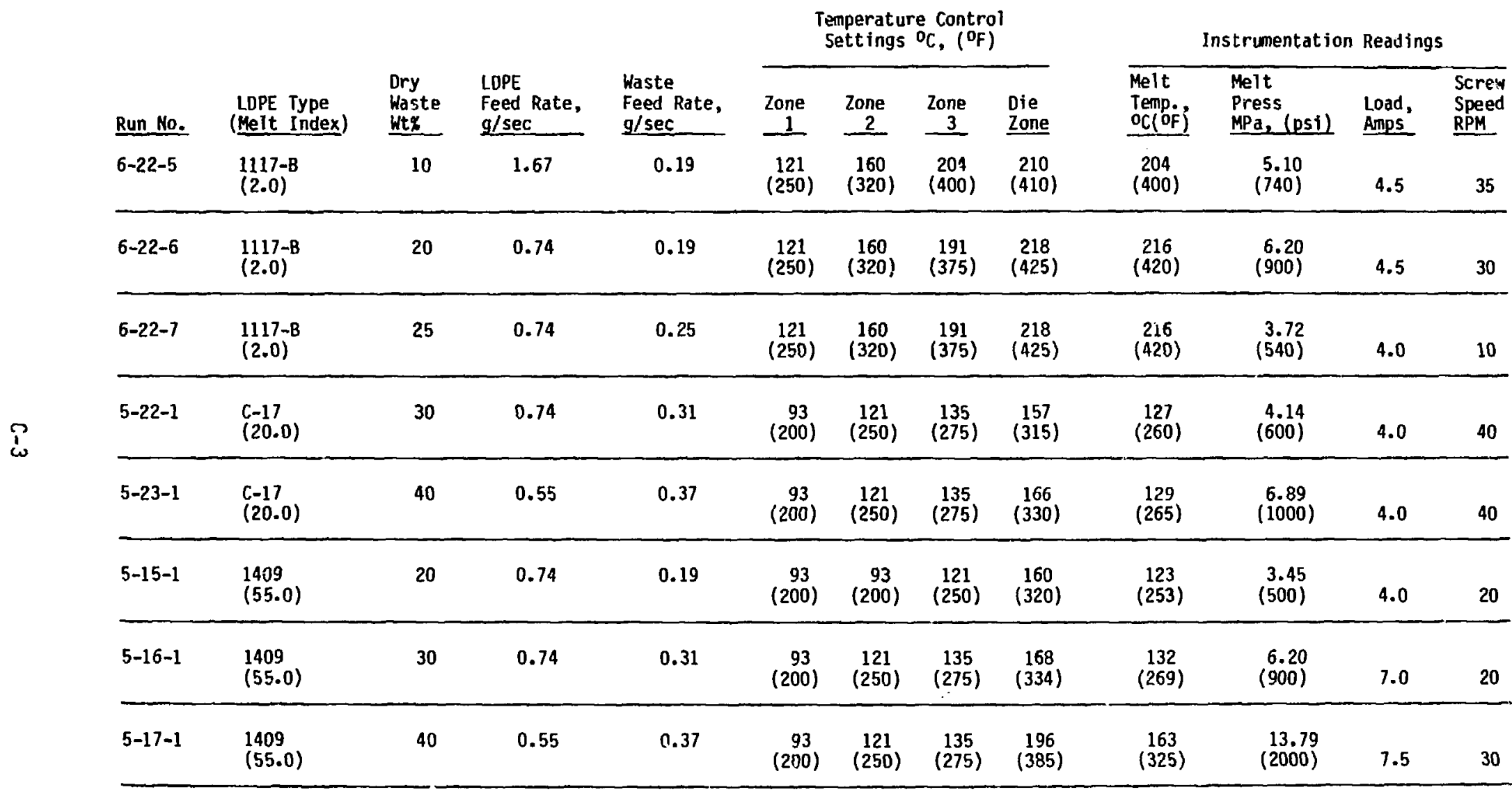


Extruder Parameters for Selected Ion Exchange Resin Solidification Formulations

\begin{tabular}{|c|c|c|c|c|c|c|c|c|c|c|c|c|}
\hline \multirow[b]{2}{*}{ Run No. } & \multirow[b]{2}{*}{$\begin{array}{l}\text { LDPE Type } \\
\text { (Melt Index) }\end{array}$} & \multirow[b]{2}{*}{$\begin{array}{l}\text { Dry } \\
\text { Waste } \\
\text { Wts } \\
\end{array}$} & \multirow[b]{2}{*}{$\begin{array}{l}\text { LDPE } \\
\text { Feed Rate, } \\
\text { g/sec }\end{array}$} & \multirow[b]{2}{*}{$\begin{array}{l}\text { Waste } \\
\text { Feed Rate, } \\
\text { g/sec }\end{array}$} & \multicolumn{4}{|c|}{$\begin{array}{l}\text { Temperature Control } \\
\text { Settings }{ }^{\circ} \mathrm{C}, \text { (OF) }\end{array}$} & \multicolumn{4}{|c|}{ Instrumentation Readings } \\
\hline & & & & & $\begin{array}{c}\text { Zone } \\
1 \\
\end{array}$ & $\begin{array}{c}\text { Zone } \\
2 \\
\end{array}$ & $\begin{array}{c}\text { Zone } \\
3 \\
\end{array}$ & $\begin{array}{l}\text { Die } \\
\text { Zone }\end{array}$ & $\begin{array}{l}\text { Melt } \\
\text { Temp.; } \\
\text { oc( } \text { Of })\end{array}$ & $\begin{array}{l}\text { Melt } \\
\text { Press } \\
\text { MPa, (psi) }\end{array}$ & $\begin{array}{l}\text { Load, } \\
\text { Amps }\end{array}$ & $\begin{array}{l}\text { Screw } \\
\text { Speed } \\
\text { RPM } \\
\end{array}$ \\
\hline $7-18-1$ & $\begin{array}{l}1117-B \\
(2.0)\end{array}$ & 30 & 1.50 & 0.64 & $\begin{array}{c}93 \\
(200)\end{array}$ & $\begin{array}{c}135 \\
(275)\end{array}$ & $\begin{array}{c}135 \\
(275)\end{array}$ & $\begin{array}{c}177 \\
(350)\end{array}$ & $\begin{array}{c}132 \\
(270)\end{array}$ & $\begin{array}{r}12.75 \\
(1850)\end{array}$ & 5.0 & 20 \\
\hline $7-19-1$ & $\begin{array}{l}1117-B \\
(2.0)\end{array}$ & 40 & 1.50 & 1.00 & $\begin{array}{c}93 \\
(200)\end{array}$ & $\begin{array}{c}135 \\
(275)\end{array}$ & $\begin{array}{c}135 \\
(275)\end{array}$ & $\begin{array}{c}177 \\
(350)\end{array}$ & $\begin{array}{c}129 \\
(264)\end{array}$ & $\begin{array}{r}13.79 \\
(2000)\end{array}$ & 5.0 & 18 \\
\hline $1-31-1$ & $\begin{array}{l}1117-B \\
(2.0)\end{array}$ & 50 & 1.00 & 1.00 & $\begin{array}{c}93 \\
(200)\end{array}$ & $\begin{array}{c}121 \\
(250)\end{array}$ & $\begin{array}{c}149 \\
(300)\end{array}$ & $\begin{array}{c}163 \\
(325)\end{array}$ & $\begin{array}{c}149 \\
(300)\end{array}$ & $\begin{array}{r}13.79 \\
(2000)\end{array}$ & 5.0 & 30 \\
\hline $1-24-1$ & $\begin{array}{l}1410 \\
(35.0)\end{array}$ & 28 & 1.50 & 0.58 & $\begin{array}{c}93 \\
(200)\end{array}$ & $\begin{array}{c}93 \\
(200)\end{array}$ & $\begin{array}{c}110 \\
(230)\end{array}$ & $\begin{array}{c}124 \\
(250)\end{array}$ & $\begin{array}{c}109 \\
(229)\end{array}$ & $\begin{array}{c}9.65 \\
(1400)\end{array}$ & 5.0 & 35 \\
\hline $1-25-1$ & $\begin{array}{l}1410 \\
(35.0)\end{array}$ & 50 & 1.00 & 1.00 & $\begin{array}{c}93 \\
(200)\end{array}$ & $\begin{array}{c}93 \\
(200)\end{array}$ & $\begin{array}{l}110 \\
(230)\end{array}$ & $\begin{array}{c}121 \\
(250)\end{array}$ & $\begin{array}{c}109 \\
(228)\end{array}$ & $\begin{array}{l}11.72 \\
(1700)\end{array}$ & 5.0 & 30 \\
\hline $1-26-1$ & $\begin{array}{l}1410 \\
(35.0)\end{array}$ & 60 & 0.67 & 1.00 & $\begin{array}{c}93 \\
(200)\end{array}$ & $\begin{array}{c}93 \\
(200)\end{array}$ & $\begin{array}{c}121 \\
(250)\end{array}$ & $\begin{array}{c}134 \\
(274)\end{array}$ & $\begin{array}{c}124 \\
(255)\end{array}$ & $\begin{array}{r}14.48 \\
(2100)\end{array}$ & 5.0 & 40 \\
\hline $1-30-1$ & $\begin{array}{l}1409 \\
(55.0)\end{array}$ & 60 & 0.67 & 1.00 & $\begin{array}{c}93 \\
(200)\end{array}$ & $\begin{array}{c}93 \\
(200)\end{array}$ & $\begin{array}{l}121 \\
(250)\end{array}$ & $\begin{array}{c}138 \\
(280)\end{array}$ & $\begin{array}{c}123 \\
(253)\end{array}$ & $\begin{array}{c}7.58 \\
(1100)\end{array}$ & 5.0 & 30 \\
\hline $1-30-2$ & $\begin{array}{l}1409 \\
(55.0)\end{array}$ & 65 & 0.54 & 1.00 & $\begin{array}{c}93 \\
(200)\end{array}$ & $\begin{array}{c}93 \\
(200)\end{array}$ & $\begin{array}{c}121 \\
(250)\end{array}$ & $\begin{array}{c}138 \\
(280)\end{array}$ & $\begin{array}{c}124 \\
(255)\end{array}$ & $\begin{array}{r}11.72 \\
(1700)\end{array}$ & 5.0 & 30 \\
\hline
\end{tabular}

